\title{
GEOTHERMAL DIRECT HEAT APPLICATIONS PROGRAM SUIMMARY
}

\section{PROGRAM REVIEW MEETING LAS VEGAS, NEVADA}

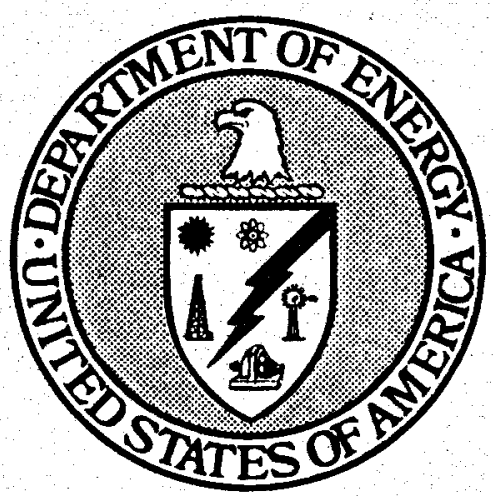

AUIGUST 1982 


\section{DISCLAIMER}

This report was prepared as an account of work sponsored by an agency of the United States Government. Neither the United States Government nor any agency Thereof, nor any of their employees, makes any warranty, express or implied, or assumes any legal liability or responsibility for the accuracy, completeness, or usefulness of any information, apparatus, product, or process disclosed, or represents that its use would not infringe privately owned rights. Reference herein to any specific commercial product, process, or service by trade name, trademark, manufacturer, or otherwise does not necessarily constitute or imply its endorsement, recommendation, or favoring by the United States Government or any agency thereof. The views and opinions of authors expressed herein do not necessarily state or reflect those of the United States Government or any agency thereof. 


\section{DISCLAIMER}

Portions of this document may be illegible in electronic image products. Images are produced from the best available original document. 


\section{ACKNOWLEDGEMENTS}

The project descriptions contained in this summary were prepared by the Project Teams of the direct heat application projects currently in progress throughout the United States. The Department of Energy gratefully acknowledges their assistance in providing this information which will assist other potential users in assessing the economic and technical viability of the direct use of geothermal energy. Additional copies of this summary can be obtained through the Department of Energy Offices listed on page 3.

At this review, the project presentations are organized according to the phase the project is in: reservoir confirmation, drilling and testing; financial and institutional concerns; system design; and system construction and operation. 
TABLE OF CONTENTS

\section{Page}

Introduction $\ldots \ldots \ldots \ldots \ldots \ldots \ldots \ldots \ldots \ldots \ldots \ldots \ldots \ldots \ldots \ldots \ldots \ldots \ldots \ldots \ldots \ldots \ldots \ldots$

DOE Project Offices ........................................ 3

Project Categories .......................................... 4

Reservoir Confirmation, Drilling, and Testing

Susanville, $C A$...................................... 4

Moana, Reno, NV ....................................... 5

El Centro, CA ......................................... 11

Financial and Institutional

Boise, ID .............................................. 15

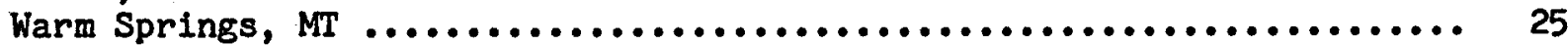

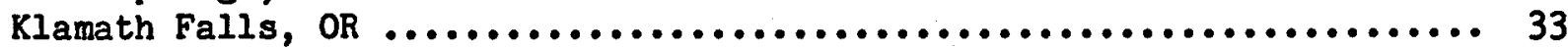

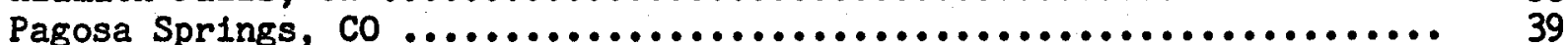

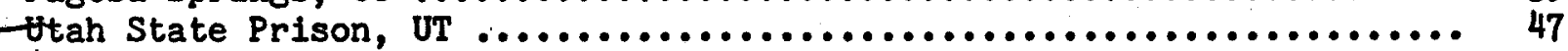

E'lko, NV ................................................ 59

System Design

Navarro College, Corsicanna, TX .............................. 69

Utah Roses, UT ........................................ 73

\section{System Construction and Operation}

Torbett-Hutchings-Smith Memorial Hospital, TX $\ldots \ldots \ldots \ldots \ldots \ldots \ldots \ldots \ldots$

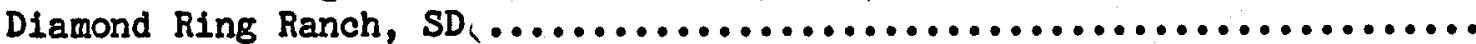

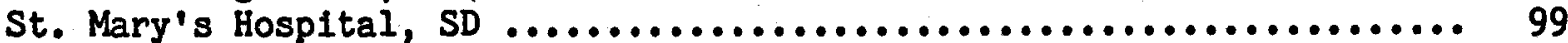

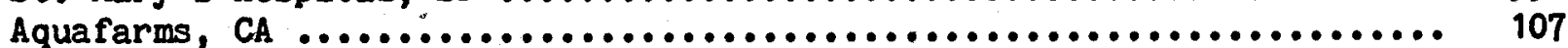

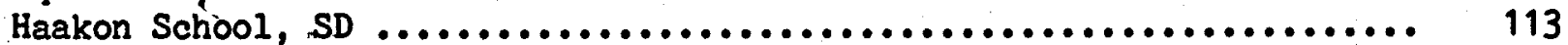


INTRODUCTION

In 1978, the Department of Energy Division of Geothermal and Hydropower Technologies initiated a program to accelerate the direct use of geothermal energy, in which 23 projects were seleoted. The projects, all in the western part of the United States, cover the use of geothermal energy for space conditioning (heating and cooling) and agriculture (aquaculture and greenhouses). Initially, two projects were slated for industrial processing; however, because of lack of geothermal resources, these projects were terminated. of the 23 projects, seven were successfully completed, ten are scheduled for completion by the end of 1983, and six were terminated for lack of resources.

Each of the projects is being documented from its inception through planning, drilling, and resource confirmation, design, construction, and one year of monitoring. The information is being collected, evaluated, and will be reported. Several reports will be produced, including detailed topical reports on economics, institutional and regulatory problems, engineering, and a summary final report.

To monitor progress and provide a forum for exchange of information while the program is progressing, semiannual or annual review meetings have been held with all project directors and lead engineers for the past four years. This is the sixth meeting in that series. Several of the projects which have been terminated are not included this year.

Overall, the program has been very successful. Valuable information has been gathered. Problems have been encountered and resolved concerning technical, regulatory, and institutional constraints. Most projects have been proven to be economical with acceptable pay-back periods. Although some technical problems have emerged, they were resolved with existing off-the-shelf technologies and equipment. The risks involved in drilling for the resource, the regulatory constraints, the high cost of finance, and large front-end cost remain the key obstacles to the broad development of geothermal direct use applications.

The following is a status summary of the 23 projects:

Stage

Drilling

Well Testing

Design

Construction
Project

1. Moana, NV

2. El Centro, CA

3. Utah State Prison, UT

4. Warm Springs State Hospital, MT

5. Navarro College, TX

6. Elko Heat Co., NV

7. Klamath Falls, OR

8. Susanville, CA

9. Boise, ID 


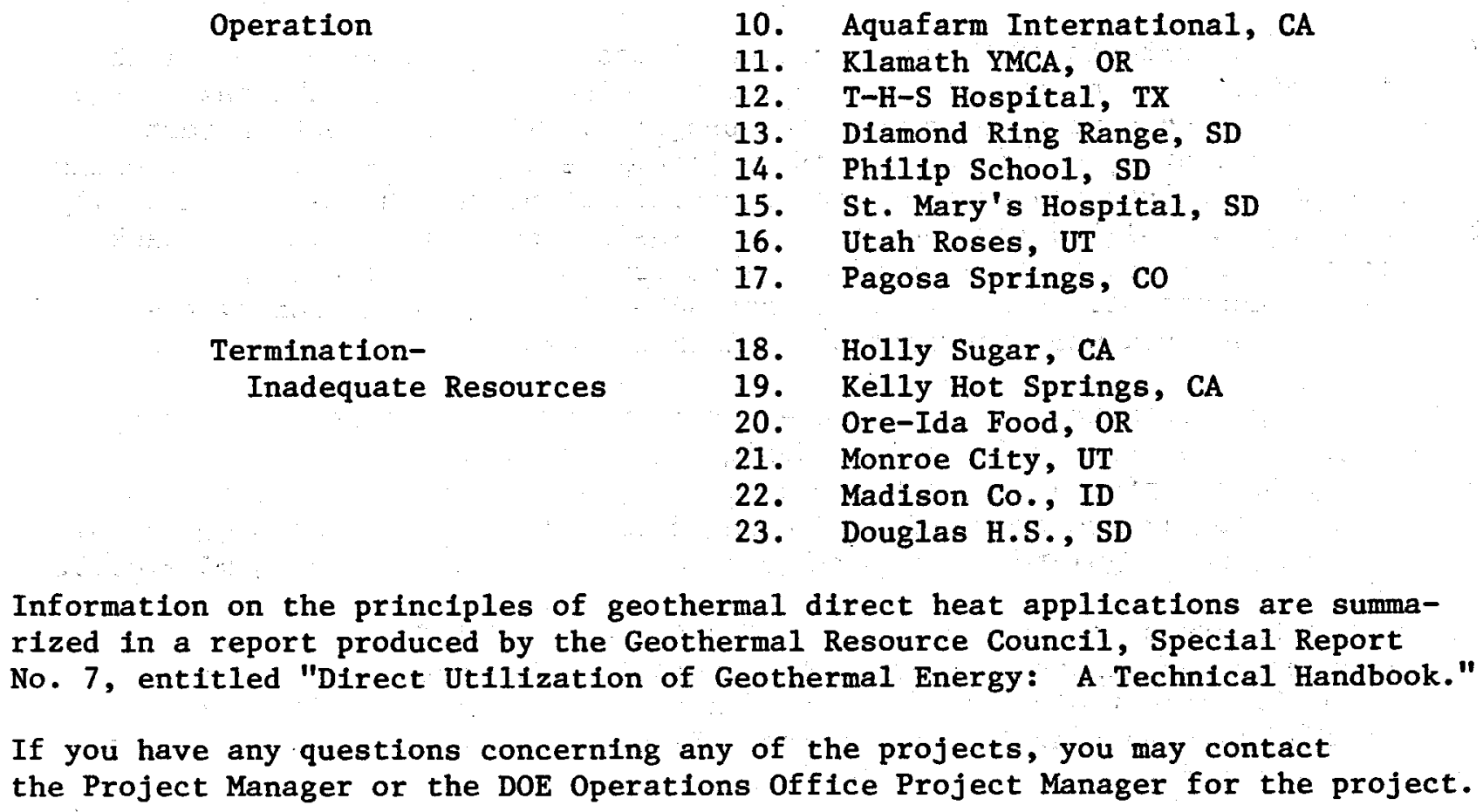

Information on the principles of geothermal direct heat applications are summarized in a report produced by the Geothermal Resource Council, Special Report No. 7, entitled "Direct Utilization of Geothermal Energy: A Technical Handbook."

If you have any questions concerning any of the projects, you may contact the Project Manager or the DOE Operations Office Project Manager for the project.

\author{
/s/ Jacob Kaminsky \\ Program Manager \\ Division of Geothermal \& \\ Hydropower Technology \\ U.S. Department of Energy
}


Three Department of Energy Operations Offices are responsible for the management of the direct heat application projects. The offices and their respective projects are:

\section{Office}

DOE-Idaho Operations Office 550 Second Street

Idaho Falls, ID 83401

Contact: Mike McLatchy Project Coordinator (208) 526-0086

Technical Support

Frank Childs

EG\&G Idaho, Inc.

Idaho Falls, ID 83415

(208) 526-9512

DOE-Nevada Operations Office

P.O. Box 14100

Las Vegas, NV 89114

Contact: Jim Cotter

Director

Energy Applications Division

(702) $734-3424$

Technical Support

Conway C. Grayson

P.0. Box $14100 \mathrm{M} / \mathrm{S} 505$

Las Vegas, NV 89114

(702) $734-3424$

DOE-San Francisco Operations Office

1333 Broadway

Oakland, CA 94612

Contact: Ken Zahora

Program Coordinator

(415) 273-7165

Technical Support

George Budney

Rockwell Energy Technology

P.0. Box 1449 - Engineering Center

Canoga Park, CA 91304

(213) 341-1000 ext. 6474

\section{Projects}

Boise

Diamond Ring Ranch

Elko Heating Company

Pagosa Springs

Philip School

St. Mary's Hospital

Utah Roses

Utah State Prison

Warm Springs State Hospital

Navarro College

T-H-S Hospital
Aquafarms International

El Centro

Klamath Falls

Moana, Reno

Susanville 
SUSANVILLE GEOTHERMAL ENERGY PROJECT

DIRECT UTILIZATION OF GEOTHERMAL ENERGY

LOCATION - NORTH END OF THE HONEYLAKE VALLEY - LASSEN COUNTY, CA.

PROJECT TEAM

City of Susanville - Project Management

Lahontan, Inc. - Construction Management/Technical-Ass istance

Koepf \& Lange, Inc. - Engineering

Aerojet Energy Conversion Company - Design and Engineering Review

GeothermEx, Inc. - Resource Assessment/Geologists

Energy Technology Engineering Center - Engineering Review

PROJECT DESCRIPTION AND SCOPE

To develóp a direct use geothermal heating district demonstration that would provide spare heating to 14 public buildings utilizing a low to moderate temperature geothermal resource. Cascaded energy from the heating district would be utilized within an economic development area (Park of Commerce).

System Design Figure 1 shows the Tayout of the system. The system was designed to utilize available off the shelf hardware. Geothermal fluids are derived from a $935^{1}$ production well capable of producting $800 \mathrm{gpm}$ (a $170^{\circ} \mathrm{F}$. Extracted fluids enter a 13,000 gallon surge tank and are distributed to the $5000^{\prime}$ eight inch temptite main line via transfer pumps housed at the well head. Return fluids for cascaded use and ultimate injection enter a 4" - 6" uninsulated return line. Fourteen public buildings along the route of the ma in line are retrofitted to utilize geothermal energy. Stainless steel tube and shell heat exchangers were utilized in all retrofits.

Project Status Construction and retrofits were completed by May 1981 . A limited check out of the system and all retrofits has been conducted and the system all set for use in the $1982 / 3$ heating season. Injection permitting and site selection became the center of controversy with the Lahontan Water Quality Control Board causing expensive delays to be incurred. The injection 
site has now been selected to the satisfaction of various Agencies and necessary construction expected to be completed in time for the coming heating season.

Reservoir Confirmation The Bureau of Reclamation, at the request of the City of Susanville, initiated under P.L. 94-156 an extensive site specific resource evaluation of the Susanville geothermal resource area that also included a general analysis of the Honeylake basin and an indepth evaluation of the Litchfield anomaly some eight miles from Susanville. In 1977 the Burec, E.R. Center and the U.S. Bureau of Mines, as a joint venture, conducted seismic refraction and reflection surveys in the southern part of Susanville through the then known geothermal resource area. From. the information derived from this effort, five shallow T.G. holes were drilled to a maximum depth of $150^{\prime}$. The temperature gradients measured in the T.G. holes, and from existing wells, indicated the thermal area was limited to the southern section of Susanville. Following the shallow T.G. program, 12 relatively deep $\left(500^{\prime}-2000^{\prime}\right)$ test holes were drilled. These wells were more extensively geophysically logged than the T.G. holes. From these 12 deep holes, it was determined that the resource was hotter at depth in the north section of the resource area (Suzy 9A). In the southern section of the resource area (Suzy $2 \& 3$ ) temperature reversals were encountered at $400^{\prime}$ and $600^{\prime}$. In the northern section no indications of temperature reversal were evident.

Well Drilling On the basis of the Bureau of Reclamation's work, a limited pump testing of Suzy $9 \mathrm{~A}$ was conducted to establish flow potential. It was determined that sufficient flow at temperature potential existed to select this site for the development of the first production well. On the basis of an evaluation conducted by GeothermEx. Inc., it was determined that 
a production well would be drilled to a depth of $1000^{\prime}$. Drilling of Susan I was commenced on October 15, 1980, and completed on December 2, 1980. The well was drilled with a $171 / 2^{\prime \prime}$ bit to $540^{\prime}$ and a $121 / 2^{\prime \prime}$ bit from $540^{\prime}$ to 927 . The following stratigraphic sequence was identified:

\begin{tabular}{|c|c|c|}
\hline $4 \quad 5 \quad 20$ & $\begin{array}{l}\text { Alluvial section } \\
\text { Lake beds }\end{array}$ & $\begin{array}{l}0-75 f \\
-\quad 75-280\end{array}$ \\
\hline & Tuffs & $280-700$ \\
\hline & Lake beds & $\therefore \quad 700-750$ \\
\hline & Basaltic andesite & $-\quad 750-815$ \\
\hline $50, \quad \cdots$ & Lake beds & $815-895$ \\
\hline & Basalt & $895-915$ \\
\hline & Lake beds & $915-930$ \\
\hline
\end{tabular}

Dritling conditions were more severe than anticipated due to numerous partial cave-ins of the uncased hole. A very large lost circulation zone was encountered at $475^{\prime}$. Some 275,000 gallons of water were introduced before circulation was regained. A major cave-in at $235^{\circ}-260^{\prime}$ zone required cement plugging. On completion of the open hole, logs were taken. Subsequent to logging, the well commenced to cave from several points. On the basis of the information derived from the logging, the decision was taken to set casing to prevent additional caving at shallow levels and to protect production zones identified in the $350^{\prime}-540^{\prime}$ zone. A combined solid and slotted string of $123 / 4^{\prime \prime}$ casing was run to $538^{\prime}$. The annulus between the slotted line and hole was gravel packed from $538^{\prime}$ to $320^{\prime}$. Cleaning below the $123 / 4^{\prime \prime}$ casing was carried out and 8 5/8" slotted casing was run in the $520^{\prime}-925^{\prime}$ interval with the casing landed on the bottom. The lower casing string was not gravel packed. After the $123 / 4 "$ casing had been set, Susan I flowed spontaneously and temperature of this water rose from $138^{\circ} \mathrm{F}$ to $164^{\circ} \mathrm{F}$ and flowed approximately $25 \mathrm{gpm}$. Return mud temperatures varied between $50^{\circ} \mathrm{F}$ and $72^{\circ} \mathrm{F}$ during most of the drilling period due to large amounts of make up water introduced. 
At one point where from 20 days the hole had been undisturbed, return temperatures rose to $135^{\circ} \mathrm{F}-147^{\circ} \mathrm{F}$.

Well Testing Two well pump tests were conducted. The first a 72 hour test conducted at various flow rates from $150 \mathrm{gpm}$ to $700 \mathrm{gpm}$. with tests at each point varying between 5 and 6 hours. The second a 30 day flow test conducted at a continuous flow rate of $650 \mathrm{gpm}$ and $850 \mathrm{gpm}$. The resulting deliverability of Susan $I$ is shown in Figure 2.

The first flow test was conducted with contractor's equipment immediately on well completion; the second after instalation of the system well head equipment. A Baltimore Cooling Tower was utilized to cool the produced fluids prior to disposal into an irrigation ditch. The temperatures of the fluid was reduced from $172^{\circ} \mathrm{F}$ to $110^{\circ} \mathrm{F}$ prior to mixing with river water in the irrigation ditch. 


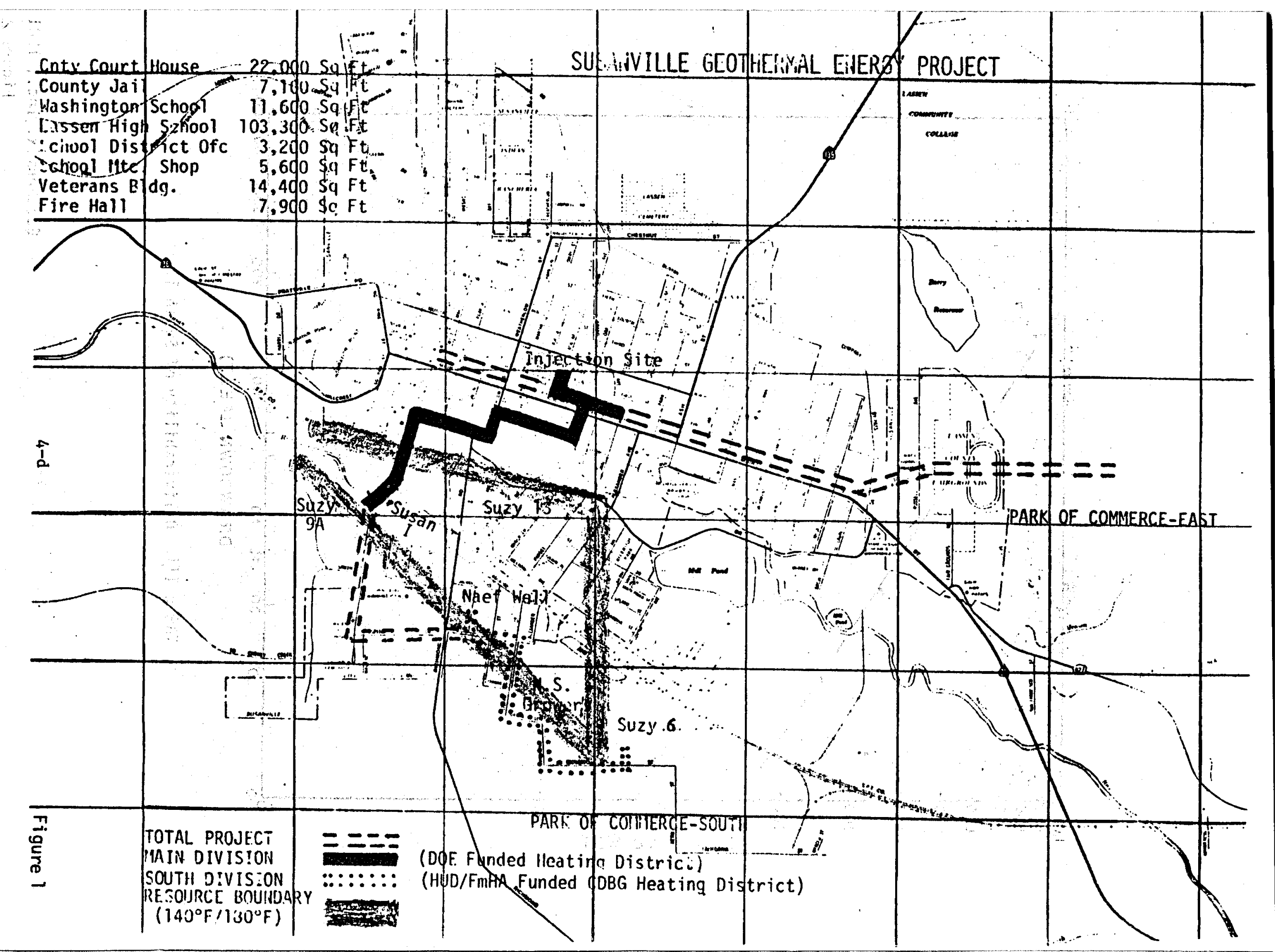




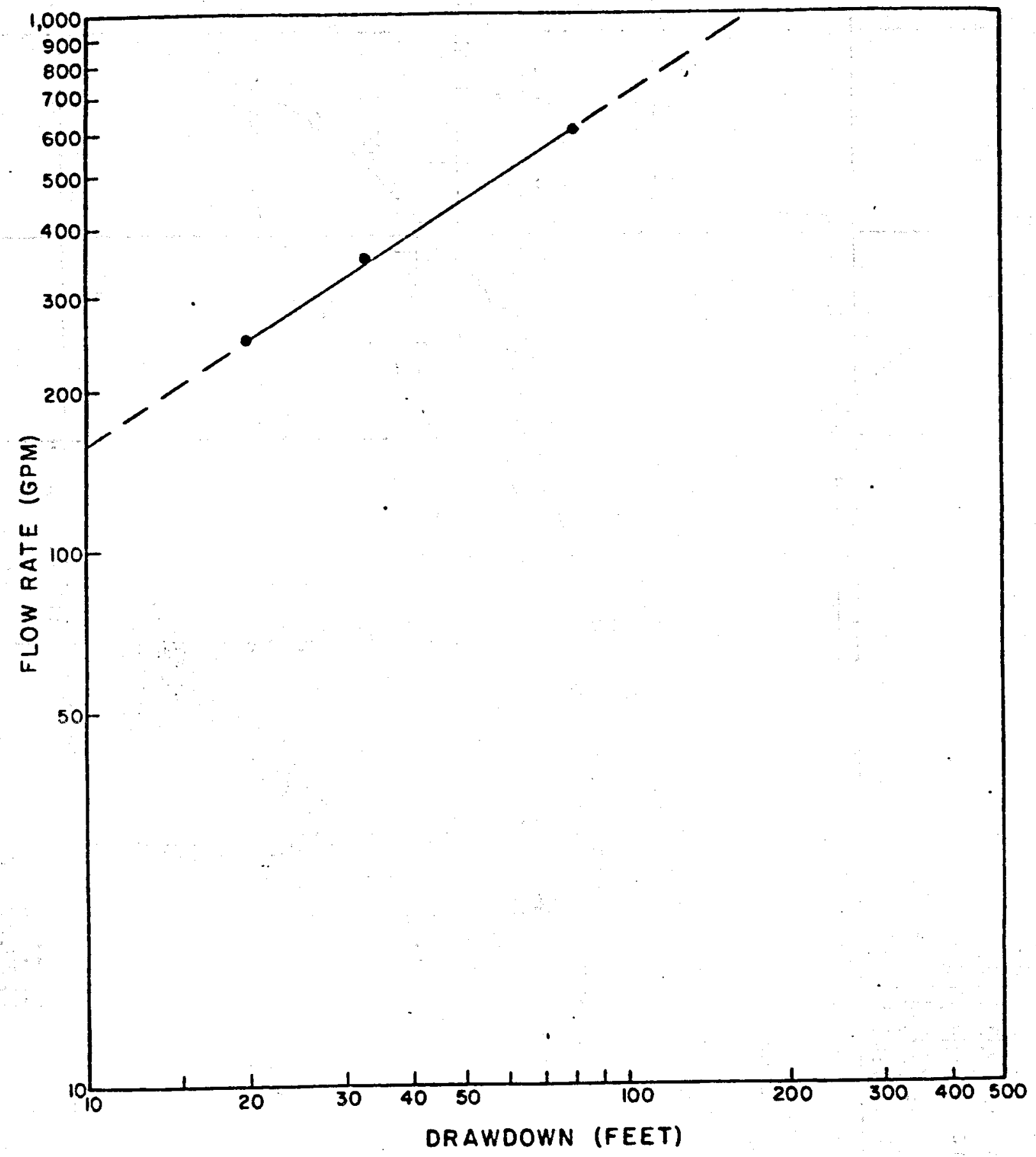

TABLE III. Deliverability of Susan 1. 


\title{
Hydrothermal Energy Corporation
}

\author{
0 \\ Main Office: \\ 6525 SUNSET BOULEVARD \\ SUITE 203 \\ LOS ANGELES, CALIFORNIA 90028 \\ 213/464-6446口 TELEX:HECLA \\ Reno Office: \\ 210 MARSH AVENUE \\ RENO, NEVADA 89509 \\ 702/323.2306
}

RESERVOIR CONFIRMATION, DRILLING AND TESTING:

MOANA PROJECT, RENO

by

Dr. David J. Atkinson

HYDROTHERMAL ENERGY CORPORATION

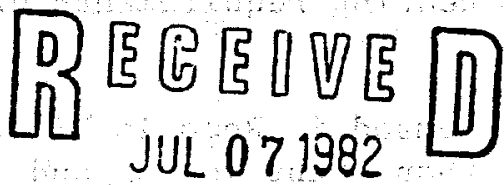

$$
\begin{aligned}
& \text { ENGINEERING } \\
& \text { AND } \\
& \text { FACILITIES } \\
& \text { MANAGGEMENT DIVISION }
\end{aligned}
$$


Parts of southwest Reno are underlain by the thermal waters of the Moana known Geothermal Resource Area (Figure 1). While the exact extent of this reservoir is not yet known for lack of sufficient wells in the area, the project discussed in this paper is located close to existing warm and hot wells, and the work we have done to date has confirmed that viable reservoir conditions exist close to the buildings to be heated.

Shallow wells drilled into the valley-fill in the Moana area have been in use for more than fifty years, heating several dozen single houses and a couple of motels, and providing domestic hot water for a small apartment complex.

These heating systems have mostly involved wells a few hundred feet deep, many of them operating without extraction of geothermal fluids and simply using downhole 'trombone' heat exchangers. A few involve extraction and distribution of the hot waters, followed by disposal to storm drains or a local irrigation ditch.

Such small-scale systems run on waters that range from about $130^{\circ} \mathrm{F}$ to near boiling point. Large-scale development and management of the resource had not been attempted prior to our work, which is designed to demonstrate the technical and economic feasibility of extensive use of geothermal energy for heating space and domestic water in residential, educational or commercial complexes in this area of Reno.

The work of this program is designed to establish a demonstration project that can subsequently become the core of a small district heating system, involving nearby apartments, condominiums and business buildings, as well as a school.

We have already completed a successful production well. Final design work is done, and construction is expected to be finished in time for the heating season of the coming winter.

\section{THE PROJECT}

In summary, this project uses geothermal heat from wells drilled into shallow aquifers of the Moana reservoir to handle all of the space and water heating requirements of a large condominium complex in southwest Reno.

Heat demand in Reno is high. The average heating season extends over more than eight months and involves 6,028 degree days of heating. Maximum demand is in January with 1,026 degree days and a normal daily minimum temperature of $18^{\circ} \mathrm{F}$. Minimum recorded temperature is $-16^{\circ} \mathrm{F}$.

The condominium complex to be heated (Salem Plaza Condominiums, on Plumas Street) has two boiler rooms in which natural gas is the heat source for circulating hot water loops that use a two pipe supplyreturn system. Space heat is accomplished with heating coils and forced air; domestic hot water is drawn off the same system, the makeup water being added upstream of the boilers. An additional gas fired 


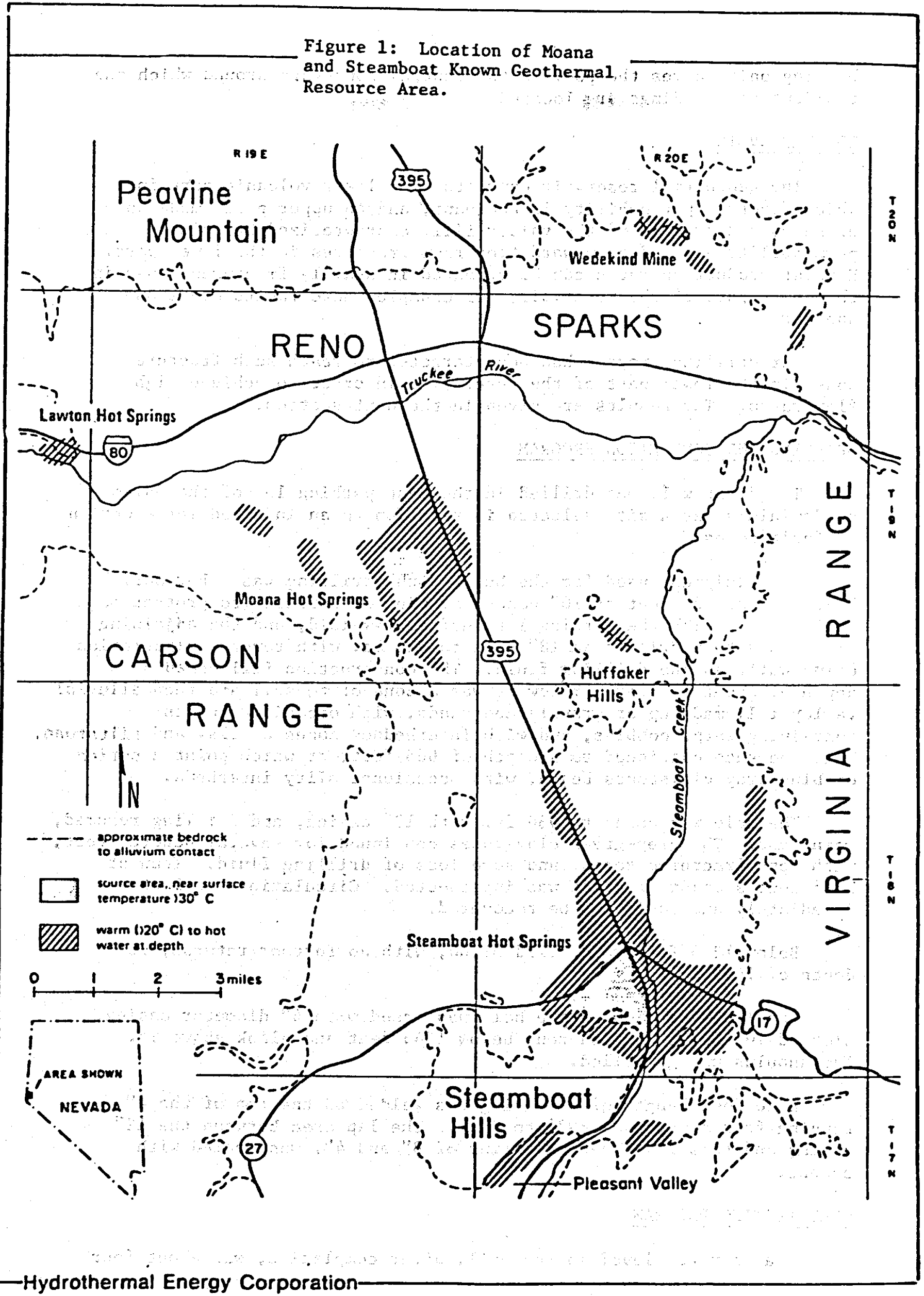


heating unit serves the pool in the central courtyard around which the residential buildings are located.

\section{THE RESERVOIR}

The geothermal reservoir consists of a lower volcanic part in which fracture permeability is dominant, and an upper part, made up of sands and gravels of the valley-fill, characterized by primary permeability and fed by upward flow from fractures in the lower part. Highest production rates can be expected in heavily fractured zones in the lower part of the reservoir, for example where faults cross one another.

Our drilling program has been targeted to reach such fracture zones in the lower part of the reservoir, in order to achieve high flow rates. The results are given in the next section.

\section{DRILLING AND COMPLETION PROGRAM}

The first well was drilled in the east parking lot of the Salem condominiums, at a site selected in relation to an inferred intersection of fault zones.

The equipment used for the bulk of the drilling was a Portadrill RV-6. We set 23 feet of $20^{\prime \prime}$ conductor pipe at surface (to protect both the fill on which the parking lot surface was laid, and the adjoining slope) and then drilled an 18" hole to $930 \mathrm{ft}$. with reverse circulation, using water as the drilling fluid. The construction fill ended at a depth of about 19 feet. Below it was a zone of topsoil and then alluvial valley-fill made up of gravels and sands, with occasional units containing large cobbles, and with interbedded zones of clay and siltstone. This sequence continued to a depth of 665 feet, at which point a series of blue-gray claystones began, with occasional silty interbeds.

The hole was cased to $930 \mathrm{ft}$. with 12" casing, and drilling resumed, using mud. The grey-green claystones continued for several hundred feet, with some fractured zones, and some loss of drilling fluid. Then at 1345 feet a major fracture was intersected. Circulation was lost immediately and could not be recovered.

Below 1345 feet we drilled blind, with no further returns, to a depth of 1491 feet.

The lower portion of the hole was cased with 4" diameter casing, slotted in the production zone below 1345 feet and blank above it. The annulus was gravelled.

A 20 foot length of 8" casing was welded to the top of the 4", running from a depth of $892^{\prime}$ to $912^{\prime}$. The lap area between the 12" casing and this lower casing string of $8^{\prime \prime}$ and $4^{\prime \prime}$, was sealed with cement.

\section{WELL TESTING PROGRAM}

Static water level in the well, after completion, was about four 
feet below the parking lot surface, or about fifteen feet above the original ground surface, as it had existed prior to construction of the condominiums.

Permission was obtained for temporary discharge into a storm drain that fed into Virginia Lake, with the proviso that the Department of Fish and Game would recelve $\$ 1.40$ for each trout killed as a result of our test pumping. Fortunately, when the test began the trout proved to be both nimble-witted and nimble-finned, and moved out to the warm edges of our discharge into the lake, appearing in fact to find the whole procedure relatively enjoyable.

Two short-term step drawdown flow tests were conducted, using a turbine pump capable of producing about $600 \mathrm{gpm}$. During the tests, flow rate, drawdown, temperature, $\mathrm{pH}$ and specific conductance were monitored. No other wells were sufficiently close to act as observation wells.

The maximum pumping rate used during the test was $580 \mathrm{gpm}$ and the maximum drawdown observed was 287 feet. Temperature was $160^{\circ} \mathrm{F}$. Specific conductance was $175 \mu \mathrm{S}$ and $\mathrm{pH}$ was 8.0 .

Based on the test observations, we concluded that sustained long-term flow would involve drawdown of less than 300 feet, and that a pump setting in the range of 350 to 400 feet would be required.

Transmissivity of the producing formation was calculated to be between 4000 and 6000 gallons per day per foot:

The pump test results confirmed that the first well was capable of supplying more than enough heat for the requirements of the condominiums.

The well would alternatively be suitable for an injection well if our second phase of drilling were to find hotter water at the other well site.

\section{GEOCHEMISTRY}

Thermal waters in the Moana region are generally of the sodiumpotassium sulphate type. They are very different from the more saline waters of the better known KGRA at Steamboat Springs, about ten miles to the south (Figure 1), which are sodium-potassium chloride waters with several thousand parts per million of total dissolved solids.

Analyses of the water from the pump tests described in the preceeding section (Table 1) showed that we are dealing with a typical Moana water, with $1025 \mathrm{ppm}$ total dissolved solids, and a $\mathrm{pH}$ of 8.0 .

\section{SPENT FLUID DISPOSAL}

For some time the State Engineer has not granted extractive water rights in the Moana area, on the basis that groundwater appropriations in this basin have already reached the limit set by Nevada regulations. Accordingly, our rights are for use of the water 
Table 1:

COMPOSITION OF GEOTHERMAL FLUID FROM THE PRODUCTION ZONE IN WELL SALEM-1

(expressed in milligrams per liter)

$\begin{array}{lc}\mathrm{Ca} & 12.2 \\ \mathrm{Mg} & 0.512 \\ \mathrm{Na} & 324 \\ \mathrm{~K} & 8.2 \\ \mathrm{HCO}_{3} & 171 \\ \mathrm{CO}_{3} & - \\ \mathrm{Cl}^{3} & 46.4 \\ \mathrm{SO}_{4} & 460 \\ \mathrm{TDS} & 1025 \\ \mathrm{pH} & 8.0\end{array}$

only to extract heat, and we are required to return it to the subsurface.

We have accordingly begun a final phase of drilling, to develop a reinjection system. The only suitable sites available for this are undeveloped lots a few blocks south of Salem Plaza Condominiums.

Our work on the reinjection program is well underway at this time. Two alternative well sites were selected for pilot tests: from the results, we shall pick the best site for the second large diameter well.

As the first well is suitable either for production or injection, the second well would be used as the production well if its temperature is higher.

This appears likely to be the case from results of our first pilot test, which has at this time reached 1675 feet and already shows a bottom hole temperature of $172^{\circ} \mathrm{F}$, two weeks after circulation stopped.

A pipeline will link the production and reinjection wells, and will pass along Salem Court, Brinkby, Berrum Lane, Berrum, and Clover. SUMMARY

We are in the last stages of executing a demonstration of largescale direct use of geothermal energy from the Moana KGRA, involving space and domestic water heating at Salem Plaza Condominiums in southwest Reno.

This report outlined the project and then described in more detail the successful drilling and completion of a production well Salem-1. and its subsequent testing. Reservoir conditions were confirmed, with temperature $\left(160^{\circ} \mathrm{F}\right)$ and flow rate $(600 \mathrm{gpm})$ being more than adequate for the requirements of the buildings.

The system will be operating in time for the coming 1982-83 heating season. 


\title{
EL CENTRO
}

\section{GEOTHERMAL ENERGY UTILITY CORE FIELD EXPERIMENT}

Principal Investigator:

\author{
Abdel Salem \\ City Manager \\ City of El Centro, California
}

Project Team: City of El Centro, WESTEC Services, Inc., Chevron Resources

\subsection{PROJECT DESCRIPTION}

The City of El Centro is conducting a geothermal energy utility core field experiment to demonstrate the feasibility of utilizing moderate temperature geothermal heat for space cooling, space heating, and domestic hot water heating. In this application, geothermal fluid at an anticipated temperature of about 250F (121C) will heat a secondary fluid (water). The secondary fluid will either be utilized directly or processed through an absorption chiller to provide space conditioning and water heating for the El Centro Community Center, a public recreational facility.

\subsection{RESOURCE DATA}

The pilot scale facility and well site for this experiment is located on a parcel of vacant land located in the northeastern sector of the City of El Centro. The El Centro Community Center is located approximately one-half mile south of this parcel. The selected area is situated on the periphery of the 13.5 square mile Heber KGRA.

\subsection{SYSTEM FEATURES}

Once the wells have been completed and tested, the pilot hot water/chilled water plant at the well site will be constructed. Heat extracted from the brine will be 
transferred to the working fluid (water) through a conventional shell and tube heat exchanger. Pressure on the brine will be maintained to prevent flashing. City supply water was selected as the working fluid because of its relatively low cost and availability. The heated water will be used in the winter for space heating and domestic hot water needs. During the summer, the heated water will be used to operate a packaged lithium bromide absorption chiller for space cooling the Community Center. The chiller will require hot water at approximately $235 \mathrm{~F}$ to produce chilled water at $42 \mathrm{~F}$ during the cooling mode. The Center will be retrofit with heating/cooling coils for the space conditioning requirements.

A total of approximately 602 million Btu/yr of energy presently consumed by the El Centro Community Center is potentially replaceable by geothermal energy. For this demonstration, the geothermal hot/chilled water plant will be sized to handle approximately 97 percent of this annual load. This means that approximately 200,000 cubic feet of natural gas and 87,000 kilowatt hours of electricity will be replaced each year by geothermal energy.

After the usable heat has been removed, the geothermal brine will be disposed of by pumping the fluid down the injection well into a shallow, comparatively cool geothermal region. Reinjection temperature of the brine is expected to be at about $160 \mathrm{~F}$.

\subsection{STATUS}

At the last review meeting, we anticipated that we would begin drilling the $4000^{\prime}$ injector and $8500^{\prime}$ producer in mid-October. Delays in deliveries of some of the casing and prolonged discussions with DOE on the justification of the subcontract award for 
drilling the wells pushed the drilling schedule to mid-December. On December 16th, drilling commenced on the injector, Thermal No. 1. On Christmas Day; a temperature survey was performed. A reading of $165 \mathrm{~F}$ was taken at 4000 '. Chevron extrapolated this to the projected depth of the producer, some 30 feet away, to $278 \mathrm{~F}$ at $8000^{\prime}$ and $298 \mathrm{~F}$ at 8500 . With this data in hand, DOE gave the project the go ahead to drill the producer. Drilling the producer proceeded without major problems. There was a requirement for additional cementing in the producer which created an unplanned for cost increase of $\$ 55,000$. The well was completed with a 5 $y_{2}$ " slotted liner and logs were run in late January. The results of the logs indicated a bottom hole temperature of approximately 302F. This temperature more than satisfied Chevron's earlier projected calculations for required bottomhole temperatures. Chevron estimated that for a $7000^{\prime}-8500^{\prime}$ completion, bottom hole temperatures of at least $269 \mathrm{~F}$ were required to produce $100 \mathrm{gpm}$ of $240 \mathrm{~F}$ fluid, the minimum acceptable surface temperature needed.

With this information in hand, the rig was released on February 1, 1982. Rather than perform a short term production test at that time, a decision was made to proceed with 30 a day production/injection test after allowing the wells to stabilize for several months.

In the latter part of June, we learned from the results of sinker bar tests that there was approximately $800^{\prime}$ of fill in the wellbore of the producer. In addition, the perforations above the fill area were obstructed so that the well would only accept fluid at an extremely low rate. Similarly, we found approximately $100^{\prime}$ of fill in the injector wellbore with the slots obstructed. Unlike the producer, however, the injector was completed by jet perforating the casing. 
The first priority is now to clean out both wells. Once the injector is capable of receiving fluids, we will proceed with cleanout of the producer. This will permit fluids produced during the 30 -day test to be injected. In order to produce, we will install a downhole submersible REDA oilfield pump. LBL and EPRI are offering their onsite assistance in downhole data gathering and well monitoring as well as fluid chemistry analysis. We expect to begin running the 30-day test by mid-July and to be in a position to begin constructing the pipeline at that time. Major system components have been procured for this follow up phase to drilling and well testing.

\section{LESSONS LEARNED:}

When undertaking the drilling of essentially wildcat geothermal wells, particularly to the depths involved in this project, assume that there will be delays and sizeable cost increases for which you have not budgeted. Flexibility in program deviations are essential to maintain project momentum.

\subsection{CURRENT ESTIMATED PROJECT COST}

Total Project Cost: $\$ 2,959,000$

DOE Share: $\$ 2,794,000$

Participant Share: $\$ 165,000$ 
PROIECT TITLE: Boise City - A Field Experiment in Space Heating

PRINCIPAL INVESTIGATOR: Phil Hanson, Director - Boise Geothemal

(208) $384-4013$

PROTECT TEAM: Boise City

Boise Warm Springs Water District

CH2M Hill, Engineers

PROTECT OBJECTIVE: To develop a geothermal space heating system to serve the largest possible market in and around the Boise central business district.

LOCATION DESCRIPTION: BOISe, Idaho

Population - 105,000

Area Activities - Commercial, governmental, manufacturing and recreational center for Idaho

RESOURCE DATA: See geologic map of resource area in Figure 1.

A. Existing Boise Warm Springs Water District (BWSWD) Wells No. I and 2.

Well Depth - 400 feet (122m)

Date Completed - 1890's

Completion Technique - open Hole

Wellhead Temperature $-170^{\circ}$ F $\left(76^{\circ} \mathrm{C}\right)$

Flowrate - 1,700 gpm combined flow of wells 1 and 2

B. New Boise Warm Springs Water District Well No. 3.

Well Depth - 600 feet

Date Completed - June 5, 1981

Completion Technique - Closed Hole

Well Head Temperature $-134^{\circ}$ F $\left(56^{\circ} \mathrm{C}\right)$

Flowrate - Inadequate

C. New Boise City Wells

- Nell Number 1

Well bepth - 2,010 feet

Date Completed - April 17, 1981

Completion Technique - Slotted Casing \& Open Hole

Wellhead Temperature - $155^{\circ} \mathrm{F}\left(68^{\circ} \mathrm{C}\right)$

Flowrate - None Artesian \& Not Yet Pump Tested

- Well Number 2

Well Depth - 800 feet

Date Completed - May 7, 1981

Completion Technique - open Hole

Welihead Temperature $-172^{\circ} \mathrm{F}\left(78^{\circ} \mathrm{C}\right)$

Flowrate - circa $900 \mathrm{gpm}$

- Well Number 3

Well Depth - 1,893 feet

Date completed - June 4, 1981

Completion Technique - Slotted Casing \& Open Hole

Wellhead Temperature - 165-170 F $\left(73-76^{\circ} \mathrm{C}\right)$

Flowrate - None Artesian \& Not Yet Pump Tested 
- Well Number 4

Well Depth - 1,103 feet

Date Completed - September 15, 1981

Completion Technique - Slotted Liner/Screen

Wellhead Temperature - $172^{\circ} \mathrm{F}\left(76^{\circ} \mathrm{C}\right)$

Flowrate - About an order of magnitude less than well \#2.

E. Summary:

The resource area is commonly referred to as the Boise Front. This appears to be fault controlled, with the source of water being the annual runoff in the mountains immediately behind Boise City. Two wells presently serve the existing BWSWD system and provide a peak flow rate of approximately 1,700 gpm. A third well was completed under the current project and was expected to increase that flow by $1,000 \mathrm{gpm}$. Results from this well were poor and it use is not planned at this time. Four new City wells have been completed as planned. Flow testing was completed on the City wells with very favorable results. The project can be completed based on these results.

SYSTEM FEATURES:

Application - District Heating

Heatload ( Design) - I x $10^{8} \mathrm{Btu} /$ hour (29.3 MW/year)

Yearly Utilization - $2 \times 10^{11}$ Btu/hour $(6.7 \mathrm{MW} /$ year)

Energy Replaced - Natural Gas, $2.92 \times 10^{8}$ cubic feet

Facility Description - 500 to 1,000 residences and up to 2,000,000 square feet of commercial building space.

Disposal Method - Disposal to Boise River is approved with backup options being reviewed.

Summary - The proposed Boise City and BWSWD systems will utilize the local geothermal resource, as described above. Production wells for the City system are lorated approximately 1.5 miles $(2.4 \mathrm{~km})$ from the primary load located in downtown Boise. The pipeline will be sized for 4,000 gpm to allow for future growth, although initial production capacity will be approximately 2,000 gpm. The EWSWD pipeline will be sized for $3,000 \mathrm{gpm}$. See pipeline maps, Figures 2 and 3.

STATUS:

Environmental Report

Geology Data Review

Well Siting Report

Preliminary System Design

Market \& Rate Study

Customer Confirmation

BWSWD Well Specifications

Boise City Well Specifications

Waste Disposal Report

Drilling Fund and Lease

Drill EWSWD Well \#3

Drill Boise City Well \#1
Completed
Completed
Completed
Completed
Completed*
In Progress
Completed
Completed
Completed
Completed
Completed
Completed

* Additional reports are in production that refine initial rate conclusions. 
Drill Boise City Well \#2

Campleted

Drill Boise City Well \#3

Completed

Drill Boise City Well \#4

Completed

Final Design of BWSWD Pipeline

Final Design of Boise City Pipeline

completed

Construction of BWSWD Extended System

construction of Boise City System

Completed

Completed

Due: October 1982

(Construction work began

6 July 1982)

PROJECT COSTS:

Total - $\$ 7,127,909$

DOE Share - $\$ 4,226,000$

Participant - $\$ 2,901,909$

LESSONS LEARNED:

The "institutional" problems and resolutions over the past twenty four months are based on a long history. The institutional issues in Boise with which we have had to deal date at least to 1975. Since these issues have acquired layers of political, legal, and organizational fact and opinion I will simply define the problem for you, describe the form which our resolution of it is taking, and try to leave you with same general conclusions.

1. PROBLEM: The State of Idaho began working with geothemal, as a heat source for their buildings, about 1974. In 1978, they connected a 34,000 foot office building to the historic Warm Springs system. Other of their activities resulted in a budget to retrofit buildings in the downtown Capitol Mall area, and a $\$ 105,000$ budget to drill an exploratory well. The exploratory well was drilled downtown, on state property, to a target depth of 2,000 feet. The product of the well was to be used to heat major state buildings which were also candidates for the planned Boise Geothermal system. The well was to have been campleted in June 1980 , but was completed in November. The problem resulting from these circumstances was our need to know the States plans so that we could design a delivery/disposal system that either did or did not include the state buildings. A second well was subsequently drilled.

RESOLUTION: Time heals all wounds, almost, aur schedule, due to funding committments, cormittee approvals, and task delay, slipped so that the states decision window will now be close to ours. Unfortunately, the decision alternatives they face have very different impacts on our project. The decision options are:

a. Connect their buildings to our distribution \& disposal system

b. Connect their buildings only to our disposal system.

c. Have no interface with the City geothermal system.

Their five buildings have a heat load of approximately $14.2 \times 10^{6}$ Btu/hour which would require about $600 \mathrm{gpm}$ of our initial production goal of 2,000 gpm.

At this time the State two well system is complete as is retrofit of their buildings. Negotiations are still proceeding toward an arrangement in which we serve their buildings, use their wells for backup disposal, and use their boiler for peaking the geothermal system. 
2. PROBLEM: Our original project was proposed to be about $\$ 9.5$ million but DOE offered to provide only $\$ 4.9$ million. This necessitated that the project be cut back and at the same time same additional funds were raised from EDA and the City. The end result was about $\$ 5.5$ million available to the project. The problem is when preliminary engineering estimates were completed we needed a total of $\$ 8.3$ million or $\$ 2.8$ million more than we had, and the City did not have that kind of funds nor was the City Council, because of the 18 initiative, willing to try raising that amount through bonds or other conventional financial mechanisms available to cities. This problem was further complicated by DOE wishing to cut about $\$ 700,000$ more out of their original committment.

RESOLUTION: The Boise Warm Springs Water District camitted $\$ 625,000$ toward the $\$ 2.7$ million of which they have obligated and spent about $\$ 265,000$ on new piping. The balance was raised through a drilling fund of about $\$ 2$ million to develop production wells

This resolution has raised the specter of another problem i.e., the drilling fund being private capital will increase the price per therm of delivered energy even though it will benefit from risk of drilling for water of the right temperature and volume. A further problem was DOE action to cut "contingency" funds fram the budget. The effect of this $\$ 700,000$ cut will not be seen unless the project encounters "contingent" conditions in any of the tasks that have to be completed. Fortunately few of these "contingent" conditions have been encountered.

3. PROBLEM: The Boise Geothermal project is a joint effort of Boise Warm Springs Water District, a special utility district of the State, and Boise City, a municipality. These two governments are totally separate and independent entities. They are sufficiently charry of each other so that in working on this joint project they have not wanted to relinquish any of their individual authorities to a conmon venture. The problem has been to determine how to make a two headed organization work.

RESOLUTION: The basic problem created by this dichotomous situation can not be totally resolved. The attempt at resolution has involved number of approaches.

a. Develop an agreement on definite ground rules for interaction between the governments. This agreement helped to clarify the relationships but has no legal force and effect.

b. Establish an Executive Comittee with members drawn equally (total of four) from BWSWD and the City. This Comittee reviews all activity and refers decisions, as appropriate, either to the Boise City Council or BWSWD Board.

4. PROBLEM: The withdrawal of large volumes of water in other parts of the U.S. has resulted in problems of subsidence and interference. The geological engineering solution to this problem is to develop a monitoring program to track changes of ground or water levels. This solution is straight forward but costly. The institutional problem created is one of finding someone to assume technical and financial responsibility for monitoring. The City believes the state should assume this responsibility, and vice versa. 
RESOLUTION: The only action taken sofar is toward a partial resolution of the problem. The State does not want to assume responsibility because they do not have sufficient financial resources for the purpose (up to $\$ 500,000$ may be required), and to add insult to injury their budget was cut in 1981 and 1982. The absense of some monitoring system poses the future threat of litigation over interference or subsidence, and if that occasion should arise it is critical to have baseline data. The action taken by Boise Geothermal is partial in the sense that we are arranging monitoring equipment to be installed on those wells now in existence and over which we have some control, as well as those we are contemplating arilling in future. If a complete program would really cost a half million dollars then our level of effort will be a very small fraction of that amount. subsequently, a year of baseline monitoring has been completed and preliminary agreements concluded to share some form of monitoring activity between present well owners.

5. PROBLEM: The use of a well drilling fund is a relatively efficient method of raising capital. The fund is predicated on committments by the City to purchase water at wholesale prices. These in turn are based on committments by building onners to purchase the water but building owners will not make comittments until they know the delivered price of the water. These prices cannot be finally determined until firm bids, on which the price is based, are received for laying the pipeline and drilling the wells. But we cannot drill wells until the drilling fund raises money.

This is further complicated by (1) the need for building owmers to convince thenselves that the retrofit and use of geothermal are to their financial benefit, and (2) the prevailing high interest rates. These complications have gotten somewhat worse as the general econamic conditions have further deteriorated and building owners have realized very large energy savings fram other less capital intensive building changes.

RESOLUTION: The needed comittments are being acquired in stages.

a. A preliminary connection agreement has been prepared for signature by building owners. It provides the owners with a maximum price for the water and the drilling fund with a preliminary committment that can be used to raise funds for well drilling. The location and success of these wells will, to a certain extent, determine the pipeline route and cost.

b. After the wells are proven and bids for the pipeline received a final connection agreement will be signed by building owners that specifies a definite price per therm. This will be backed up by a geothermal service ordinance.

c. In 1981, in an effort to speed up building owners decision making process, we have offered technical assistance in completing a cursory technical review of in building equipment and financial requirements. This has resulted in no more than four hours per building to identify ballpark figures for retrofit costs and summary evaluations of financial feasibility. As part of this effort an economic model (computer) has been produced for use by 
building owners to analyze their investment in geothermal.

6. PROBLEM: We will be producing up to $2,000 \mathrm{gpm}$ in the initial phase of our project which means, after use, we must provide for disposal of this amount of water. All of the options for disposal are under the regulatory authority of the Department of Water Resources, the U.S. EPA, State Health \& Welfare Department, the Corps of Engineers, and/or the Bureau of Iands. The preferred disposal option is to return waste water to the river. In this case Health \& Welfare and the EPA would have principal responsibility. EPA requires preparation of an NPDES but, since the volume of water is small by their stardards they will not be issuing a permit. On the other hand $\mathrm{H} \& \mathrm{~W}$ will only grant permission for disposal of a limited quantity for an indeterminate period of time. . The problem is that we will have permission to dispose of some quantity revocable at any time.

RESOLUTION: The project has worked with $\mathrm{H} \& \mathrm{~W}$ to develop a canpliance schedule for disposal of water to the Boise River. This schedule establishes a time fram to complete preparation for disposal and definition of a monitoring program for the river. The schedule also specifies levels of temperature and fluoride disposal as a function of stream flows. This compliance schedule was approved by the $H \&$ " Board in June 1982.

BOISE GEOTHERMAL

REPORT - BIBLIOGRAPHY

Boise City Energy Office, Geothermal Energy Systems Plan for Boise City, Contract No. EY-76S-97-1631, January 1979. 430 pages.

CH2M Hill, Inc., Environmental Report for a space Heating Project for the City of Boise, Idaho, Contract No. EG-78-n-03-2047. 135 pages.

Boise Geothermal, Boise Geothermal Institutional and Financial Plan for 1980 to 1983, Contract No. DE-FC07-79ET27053, April 1980. 120 pages.

Anderson \& Kelly, Considerations Related to Injection of spent Thermal Water, Boise Geothermal Project, July 1980.

Anderson \& Kelly, Recommended Sites and Areal Geology Related to Geothermal production Wells in the Vicinity of Military Reserve Park, July 1980 .

Anderson \& Kelly, Analysis of Hydrogeological Test Data for Wells $1 \& 2$, Boise Warm Springs Water District, December 1979.

Anderson \& Kelly, Baseline Assessment of Geology and Hydrogeology Boise Geothermal Project, April 1982. 25 pages.

Donovan \& Richardson, Feasibility/Conceptual Design Study for Boise Geothermal space Heating Demonstration Project Building Modifications, Aerojet Nuclear Company Report No. ANCR-1246, October 1975 . 
CH2M Hill, Preliminary Enginecring Design for City of Boise and Boise Warm Springs Water District, August 1980.74 pages.

CH2M Hill, Geothermal Retrofit of the State of Idaho Industrial Administration Building, October 1981. 50 pages.

CH2M Hill, Proposed Pipeline Network for Boise Geothermal District Heating System, August 1981. 27 pages.

CH2M Hill, Market and Rate Study for City of Boise and Boise Warm Springs Water District, August 1980,54 pages.

CH2M Hill, Geothermal Water Disposal for City of Boise and Boise Warm springs Water District, August 1980 ,

Boise State University, Eiological Impacts of Geothermal Waste Water Discharge into the Boise River, June 1978. 80 pages

Department of Energy, Geothermal Direct Heat Applications Program Summary, Semi-Annual Review Meeting in Boise, Idaho, September 1981. 189 pages.

City of Boise, Boise Geothermal System Ordinance, September 1981. 20 pages.

City of Boise, Geothermal Energy Distribution System Connection Agreement, 5 pages.

Boise Geothermal, system Start Up and Pricing Policies, February 1982 (DRAFT). 30 . pages. 


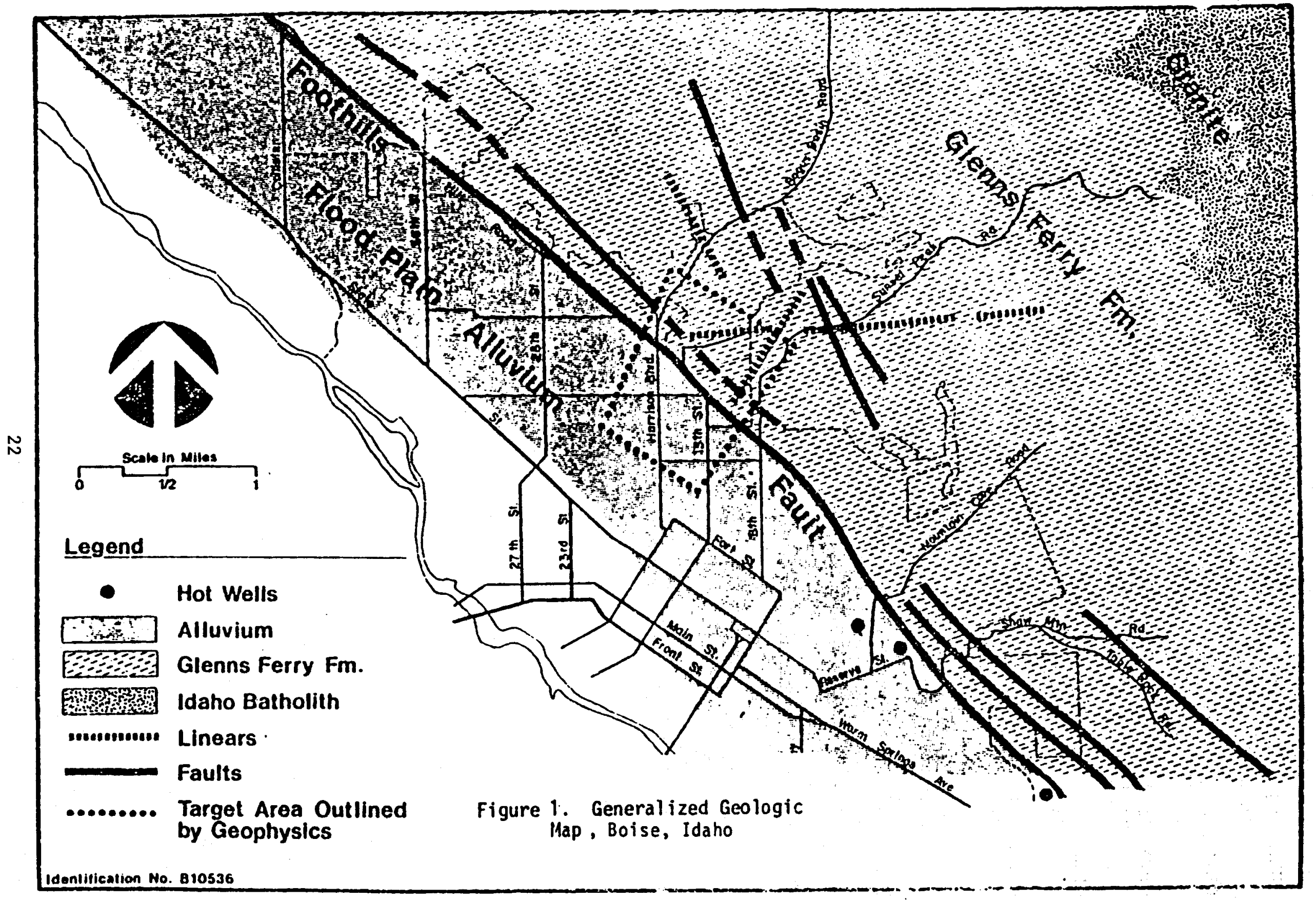


FIGURE 2.

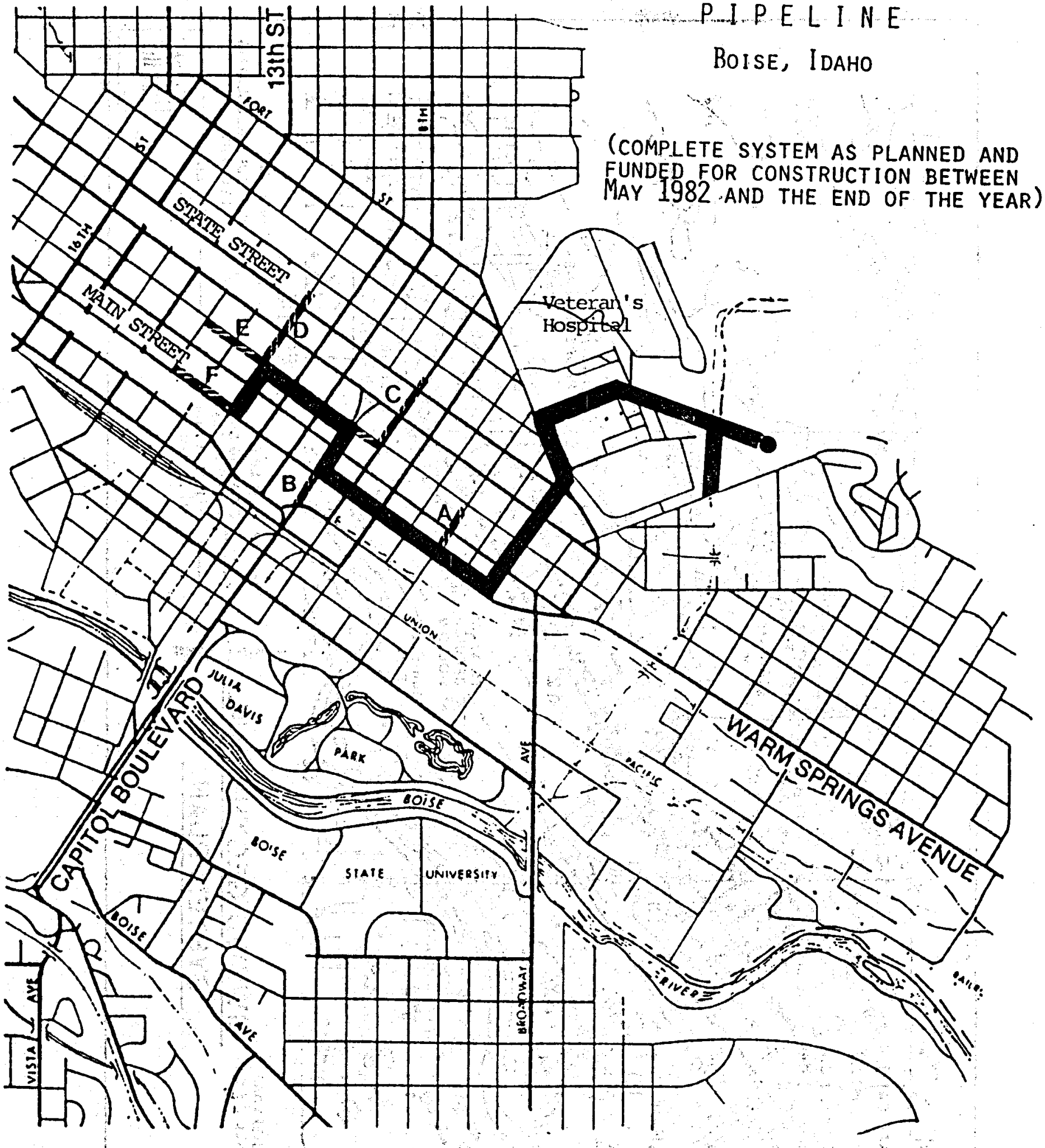

\begin{tabular}{|c|c|}
\hline $\begin{array}{l}\text { Transmission Pipeline } \\
\text { well Sites } \\
\text { Alternate A - Third Street } \\
\text { Alternate B - Capitol Blvd }\end{array}$ & $\begin{array}{l}\text { Alternate C - Bannock/Sixth Street } \\
\text { Alternate D - Tenth Street } \\
=\text { Alternate E - Bannock Street } \\
\approx \text { Alternate F - Main Street }\end{array}$ \\
\hline
\end{tabular}




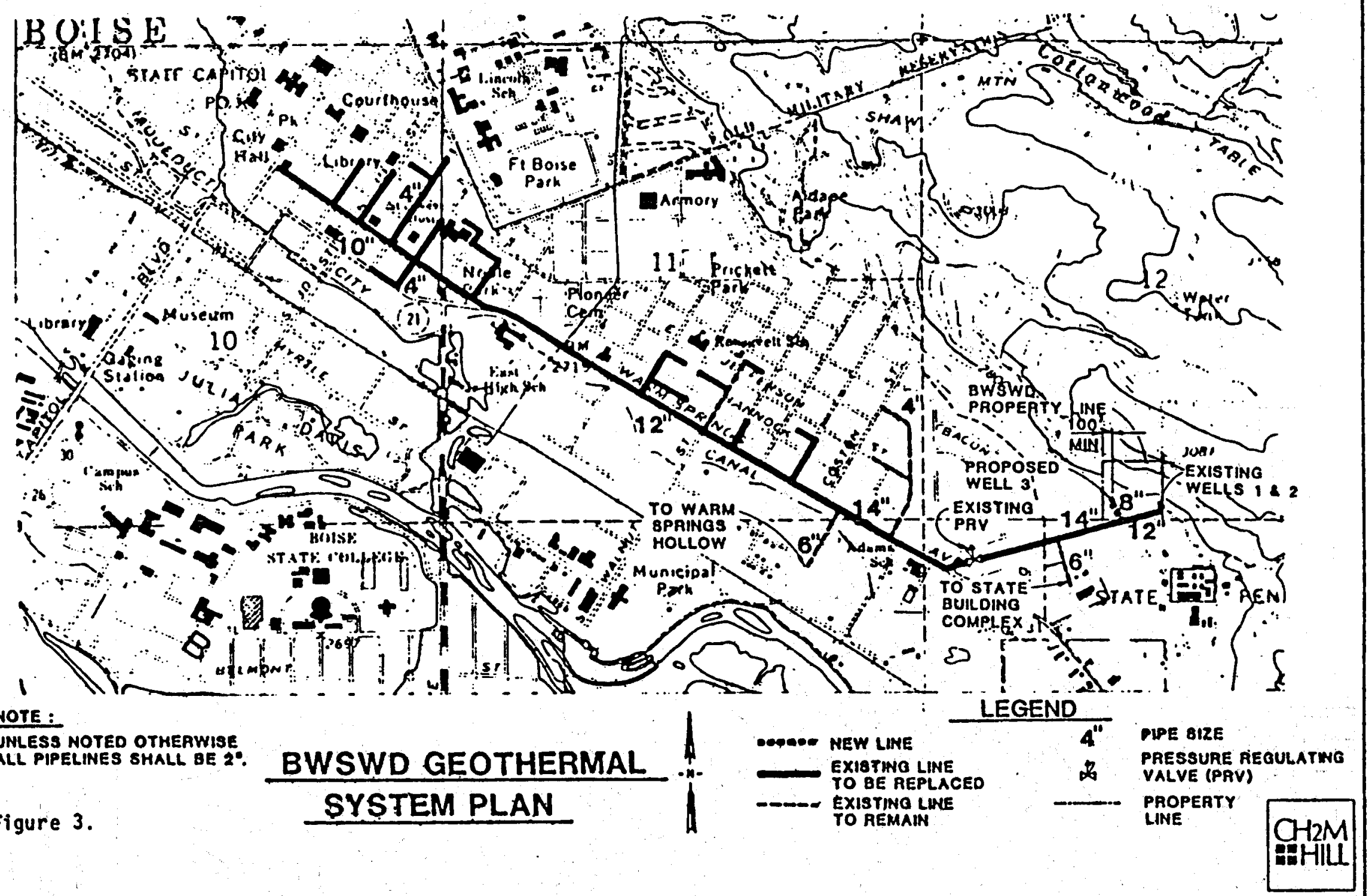


Project Title:

Principal Investigator:

Project Team:

Project Objective:

Location Description:

Resource Data:

Flow Rate:

Summary:

System Features:

Status:
Geothermal Heating of Warm Springs State Hospital

Allan D. Miller

Montana Energy and MHD Research and Development Institute, Inc.

Phone: (406) 494-6319

State of Montana

MERDI, Inc. (aka MultiTech, Inc.)

Energy Services, Inc.

$\mathrm{CH}_{2} \mathrm{M} \mathrm{Hill}$, Inc.

To develop geothermal resources at Warm Springs for domestic water and space heating.

Warm Springs State Hospita]

Deer Lodge County, Montana

15 miles (24 kilometers) south of Deer Lodge

Population: 10,700 (Deer Lodge County)

Area Activities: Mining, State Hospitals, and Agricultural:

We11 depth 1,498 feet ( 457 meters)

Date Complete: 12/5/79

Reworked: $4 / 20 / 81$

Completion Technique: Slotted liner

Well Head Temperature: $168^{\circ} \mathrm{F}\left(76^{\circ} \mathrm{C}\right)$

$70 \mathrm{gpm}$ (4.41 liters per second) required for system design.

Warm Springs is located adjacent to the State Hospital and discharges $168^{\circ} \mathrm{F}\left(76^{\circ} \mathrm{C}\right)$ water with a dissolved solids content of $1250 \mathrm{mg}$ per liter. The source of the geothermal fluid is attributed to deep circulation in fault zones.

Application: Domestic water heating Heat Load Design: 1.05 BTU per hour Yearly Utilization: $60 \%$ of $70 \mathrm{gpm}, 70^{\circ} \mathrm{F}$ temperature drop

Yearly BTU Utilization: $12.87 \times 10^{9}$ BTU per year

Energy Replaced: $\quad 15.518 \times 10^{6} \mathrm{ft} / \mathrm{yr}$ of natural gas $\left(829.5 \mathrm{BTU} / \mathrm{ft}^{3}\right.$ )

Value of Energy Replaced: $\$ 68,092$ (based on $\$ 4.388$ / $1000 \mathrm{ft}^{3}$ )

Disposal Method: Surface discharge to migratory waterfowl wetlands

The Warm Springs State Hospital Project was initiated in February of 1979 with an Environmental Assessment, Resource Evaluation, and a Legal/Statutory Review. 
The Environmental Assessment addressed both human and natural environmental factors to determine the impact of the project on the surrounding area.:

The Legal/Statutory Review was conducted to determine legal requirements which must be met prior to, during, and after development of the project.

The Resource Evaluation was conducted to determine the most favorable geological location for siting of the well. The evaluation study consisted of 1) a gravity and resistivity survey by the Montana Bureau of Mines and Geology in the immediate area of the existing hot springs mound; 2) evaluation of existing reports, maps, surveys, and studies of the immediate Warm Springs area; and 3) review of two independent studies made of the Deer Lodge Valley which resulted in mapping of three probable faults running northeast to southwest and north to south.

In reviewing all of the above data, the well was sited northeast of the existing hot springs mound in the area of the facilities heating plant (see Figure 1).

Drilling activities began in mid-October of 1979 and were completed in early December of 1979 to a TD of 1,498 feet (See Figure 2 for diagram of the well completion).

Logs run in the well were: 1) Dual Induction Later $\log$ was run in the uncased section from 898 to 1501 feet; 2) Compensated Neutron Formation Density was run from 420 feet to 1501 feet; and 3) Temperature $\log$ run from 50 feet to 1501 feet. Also, two water samples were taken to determine Rw (formation water resistivity).

Some preliminary pump tests were run and then the decision was made to perform matrix acid treatment of the well. Based on an analysis of acid reaction to the well cutting, hydrochloric acid was chosen. The job consisted of pumping 4000 gallons of 15\% hydrochloric acid down the drill pipe and displacing the acid by pumping fresh water down the annulus side. The pressure was bled off and the well was shut in for 24 hours. Several days later a pump test was conducted and the well flowed $200 \mathrm{gpm}$ for 2 hours at $160^{\circ} \mathrm{F}$. However, the test was stopped due to pump failure. 


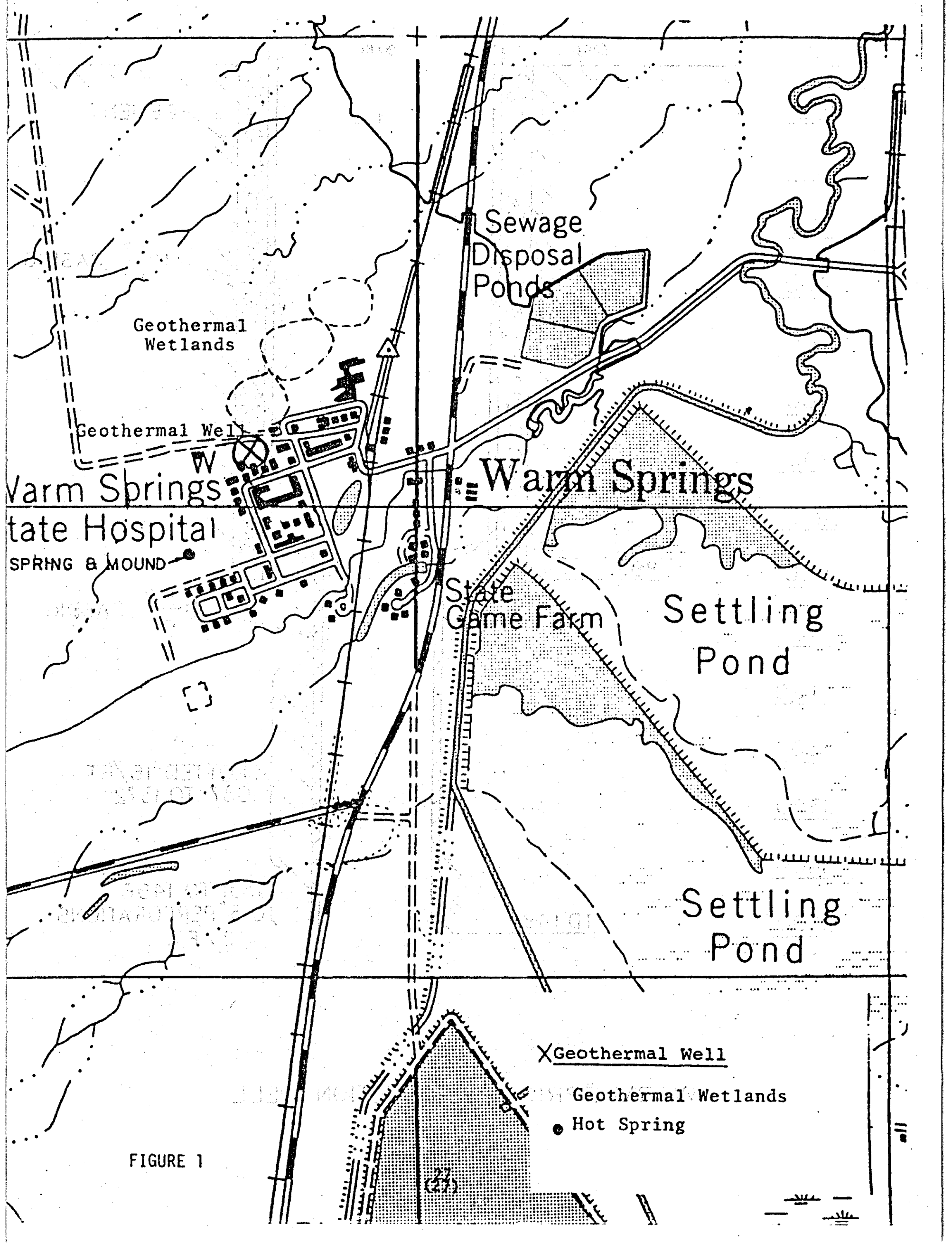




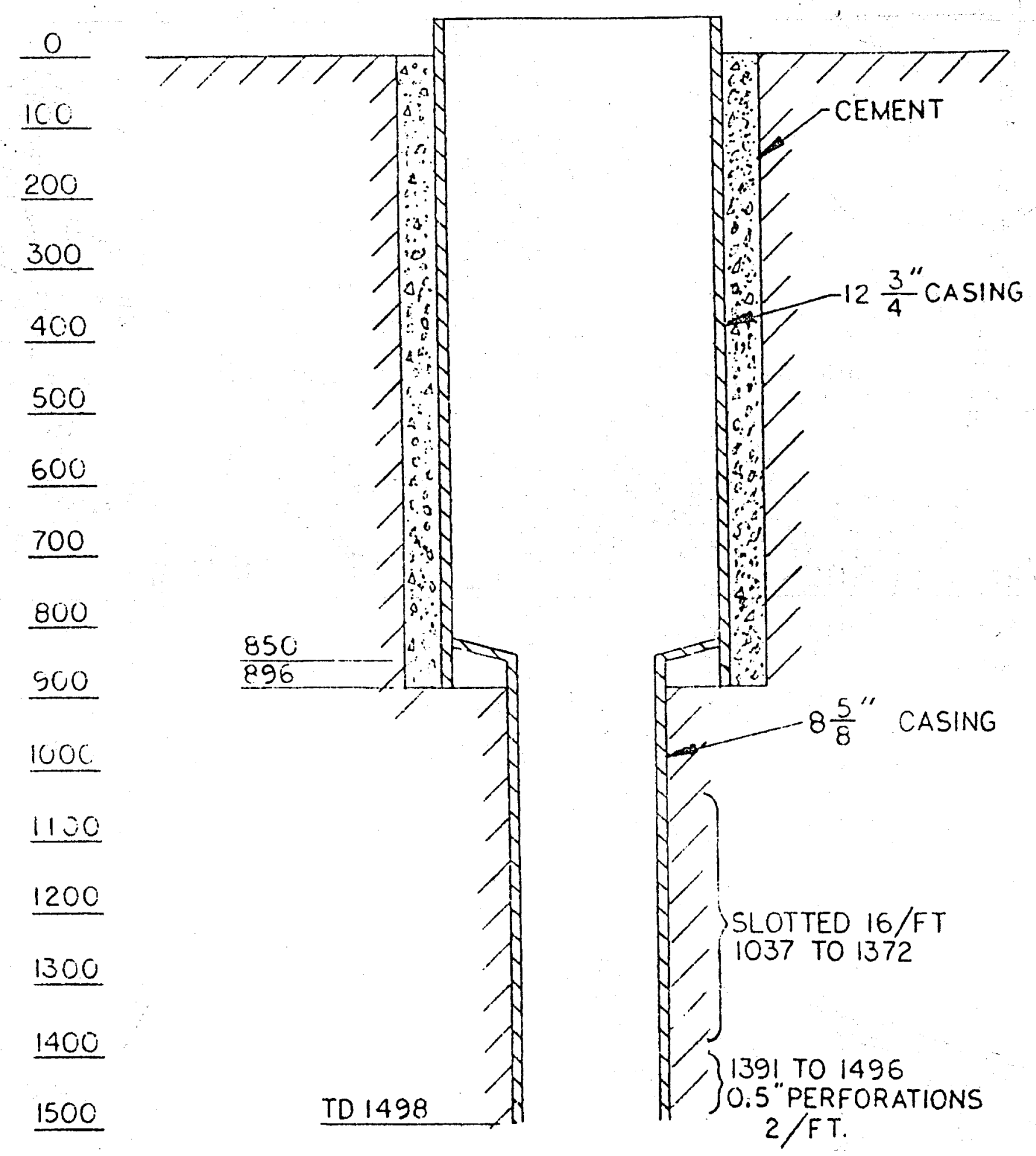

WARM SPRINGS PRODUCTION WELL

FIGURE 2 
Status Continued: MERDI then contracted with a pump company to install a new Worthington line shaft vertical turbine pump. This pump was set at 830 feet. The pump consisted of 19 stages with spider bearings set on a stainless steel shaft every 10 feet. The pump test was plagued with vibration problems. One or two hours was the maximum running time of the pump during any single test. This lasted for several weeks for a total running time of less than 52 hours. Examination revealed that the elastomer spiders had failed, the bubbler tube had sheared off and the pump intake screen had been lost downhole. Actual cause of the vibration problem has never been settled.

In January 1981, Energy Services, Inc. (ESI) of Idaho falls, submitted a report to MERDI on their evaluation of the Warm Springs well. The report's conclusions supported recommendations of reworking the well and drilling an additional 50 feet into what was believed to be a zone of hot water. EIS's recommendations were approved by the Department of Energy and work commenced on March 12, 1981. It was initially found that the bottom 220 feet was filled with drilling mud and rock chips. In addition, a 12 foot piece of $3 / 8$ inch steel pipe was retrieved. After cleaning the well to the total depth, a solid'metal item was struck in the bottom of the hole, probably a length of drill pipe lost previously. However, fishing attempts were unsuccessful at retrieving the metal. Since drilling was unsuccessful at going through or around the metal, the decision was then made to perforate the bottom 120 feet of casing with two $1 / 2^{11}$ jet perforations per foot. The well was then swabbed and cleaned for several days. The results were the artesian flow increased from an estimated 20 to 22 $\mathrm{gpm}$ to 32 to $35 \mathrm{gpm}$.

A 30 HP Reda G75 downhole submersible pump was Installed on May 19, 1981 to a setting depth of 987 feet. The pump was test run by a Reda representative for approximately $1 / 2$ hour. On May 23 long-term testing commenced.

The well was tested at rates of 50, 75, 95 and 110 $\mathrm{gpm}$, for 100 hours each, with required recovery: time. After the final recovery of the $110 \mathrm{gpm}$ test, a nine hour step drawdown of 25,50 ; and 75 gpm was run for three hours at each gpm rate. 
Status Continued:

Results of the tests were:

Test Rate
(gpm)

50

75

95

110
Test Tire (hrs)

100

100

100

100
Maximum Drawdown (feet)

815

900

870

860
Recovery time

(hrs)

3.4

3.8

2.9

2.5

The main purpose of the step drawdown test was not to determine well efficiency but to gather data on optimum pumping rate of the well. Since this is a devloping well, as evidenced by the data obtained, the test cannot give any valid conclusions about well efficiency.

Design of the Domestic Hot Water Heating system has been completed. It incorporated a 316 stainless steel plate type heat exchanger for primary heat transfer. A vent and vacuum valve, solids separations, and flow indicator are the other essential components on the geothermal pump loop. Discharge of the spent geothermal water is to a Montana Department of Fish, Wildlife, and Parks waterfowl wetlands project (see Figure 3 for P\&I diagram).

All domestic cold water makeup is routed through the heat exchanger to supply the demands of the facility. A BTU flow meter is installed on the domestic water loop to compute the total amount of the geothermal resource utilized. Additional pressure and temperature safety devices are included in that loop as well as the normal pressure and temperature gauges.

Project bids have been received and the construction contract has been let. Equipment ordering is underway and construction is proceeding. The system will be in operation this fall.

Current Revised Estimated Project Cost:

Total :

$\$ 752,501$

DOE Share:

$\$ 721,122-95.8 \%$

Participant Share: $\$ 31,379-4.2 \%$ 


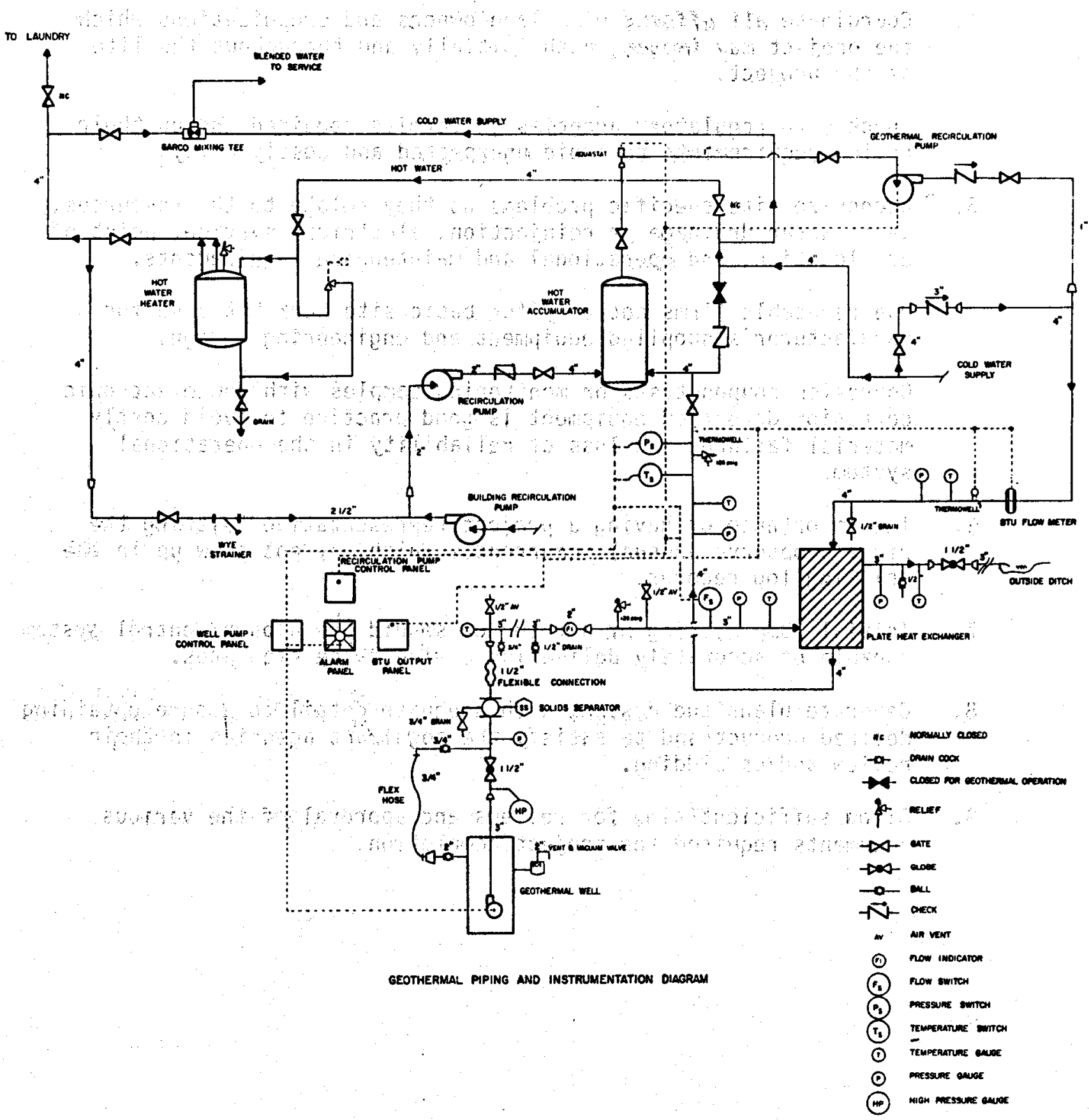

FIGURE 3 


\section{Lessons Learned:}

1. Coordinate all efforts with land owners and organizations which the project may impact, both initially and throughout the life of the project.

2. Check with regulatory agencies on permits required and on their review requirements to avoid unexpected and costly delays.

3. Recognize site specific problems as they relate to the resources, waste water drainage or reinjection, electrical service, point of use location, and operational and maintenance requirements.

4. Use reputable firms not only for basic site work but also for manufacturer's supplied equipment and engineering design.

5. Corrosion coupon tests or monitoring samples with new electronic corrosion detection equipment is good practice to avoid costly material failures and loss of reliability in the operational system.

6. The importance of having a project representative "sitting the rig" to observe unusual occurrences which may not show up in the drilling $\log$ records.

7. Initial pump testing of a resource should use a pump/control system capable of accurately delivering a wide range flowrates.

8. Generate plans and designs with adequate detail to assure obtaining desired product and to satisfy the cognizant agencies in their review and/or bidding.

9. Allow sufficient time for reviews and approval of the various documents required for project completion. 
KLAMATH FALLS GEOTHERMAL HEATING DEMONSTRATION PROJECT

Harold Derrah

The Klamath Falls project was Intended to demonstrate the feasibility of using geothermal heat initially for the heating of 14 government buildings. The project involves several components, including production wells, primary pipeline, central heat exchanger facility, and secondary closed loop which delivers the heat to the building. The project was intended to demonstrate the engineering and economic feasibility of geothermal district heating initialiy within a non-density area.

PROJECT DESCRIPTION

The project as initially designed provided for the drilling of two geo-

thermal production wells. Production wells were chosen from City owned land within a mile of the downtown area. The well sites also had easy access into public rights-of-way for the eventual installation of pipeline. The drilling was completed in late 1979. The City has gone through several pump tests to determine reservoir capabiltities in relationship to the project and also surrounding wells. The first pump test conducted on Well \#1 was for $15 \frac{1}{2}$ hours at a flow rate of $680 \mathrm{gpm}$ and a discharge temperature of $218^{\circ}$. Based on that pump test, calculated transmissivity values indicated permeability of approximately i100 darcies. Based on interpolation by the Lawrence Berkeley Laboratory, expected drawdowns would be from 2 to 3 feet, a sustained production rate of $680 \mathrm{gpm}$. In order to verify construction installation of the plpeline and exchanger facilities, the City has conducted other systems tests, and during the systems tests, have measured drawdown on production wells and the surrounding wells.

The City, in February of 1982, completed a five day systems test of the system 
and the reservoir data obtained verified the results of the $15 \frac{1}{2}$ hour test previously concluded. Both well production zones are in the area of 190 feet to 350 feet. Both pumps have been fitted with variable speed pumps which are run by outside temperature and pressure influences which regulate demand on the pumping. The system was selected as we felt it permitted more efficient use of the resource.

\section{Primary Line to Heat Exchanger:}

When well sites had been identified, the next step was to determine how the hot water should be transported from the wells to the large heat exchanger where the heat would be transferred to the secondary line and distributed in the downtown area. The city had little trouble selecting the route for the primary line since it was an almost direct line from the production wells down a major city street to the County Museum where the heat exchanger building and reinjection wells would be located.

More time was spent selecting a pipe technology for the line. While the City arrayed a total of 16 different options, the principal choice was between a line buried in the street and one enclosed in a concrete conduit with a removable lid doubling as a sidewalk. Eventually, influenced by our study of Icelandic systems, we attempted the conduit approach. As constructed, the primary line consists of an eight-inch steel pipe surrounded by two inches of urethane running 4,100 feet from the wells to the heat exchanger. Although initially more expensive than buried pipe, the city team felt it allowed greater flexibility for future expansion, and would be easier to maintain. As a small bonus, there would be a long stretch of City sidewalk that would never need snow shoveling again.

Reinjection System: 
Several options were discussed for disposal of the geothermal waters. The primary ones included discharge into the waste water system, reinjection near the production well, and reinjection at some point farther away. Despite the fact that present users already discharged over $3,000 \mathrm{gpm}$ into storm sewers, we preferred to try to conserve the resource as much as possible and proposed to reinject the water back into the aquifer. However, reinjection back in the well field, we felt, ran the risk of "poisoning the well"' if the cooler reinjected water came in contact with the well water. The option finally chosen was reinjection down the existing well at the County Museum, a distance of about 2,500 feet from the production well, and far enough away to eliminate the risk of cooling.

The secondary line takes the geothermally heated fluids which are a part of a domestic closed loop system from the exchanger building to the 14 buildings, and runs approximately 7,000 feet. The pipeline is direct buried, is plastic pipe with 2 inches of polyurethane insulation with the exception of the initial footage, which is 10 inch steel pipe. The line was sized to accommodate all the buildings along which it proceeds. The City also installed " $T$ ' $s$ " for possible future connection at every cross street for the existing buildings along the line.

\section{PROJECT ECONOMICS}

The following is the estimated project cost for completing the project:

Item Description

Production Wells

Primary Pipeline

Secondary Pipeline

Engineering \& Administration

Total
Amount

$$
63,965
$$

$1,269,711$

790,966

205,468
Status

Complete Complete Construction in process

For economic evaluation the lowest existing energy source avaflable to the 14 buildings was used for comparison. That energy form is natural gas. Inflation 
rates were used through a ten-year period escalating natural gas costs to 82c per therm. The economic evaluation indicates that at 31 \& per therm the 14 building project would have a payoff in 6.2 years, based on a present worth of $8 \%$ and the cost of capital of $8 \%$. A 20 year equivalent cost summary was also completed for the 11 block area. That equivalent annual cost summary, including operation and maintenance costs, shows an annual equivalent cost for geothermal of $\$ 216,096$ per year versus $\$ 576,994$ per year for natural gas. It should be noted that in completing the 20 year annual equivalent cost, $82 c$ per therm for natural gas was used. That figure, by current indications, seems to be very conservative and through the coming 20 year period should escalate considerably higher, placing the geothermal project in yet a more favorable position.

\section{PROJECT STATUS}

The project is essentially $100 \%$ complete with some minor construction to be completed. Because of the concern of the existing well owners, the City is also designing and constructing a waste discharge collection system which will, when completed, collect existing discharge fluids from existing geothermal wells, place them in the primary pipeline, run the fluids to the central heat exchanger building, and then heat the plate heat exchangers and transfer the heat to the secondary loop.

\section{PROBLEMS ENCOUNTERED}

The main problem encountered in the Klamath Falls project is centered around existing wells. Existing well owners have been concerned of a possible drawdown from direct pumping and injection 2,500 feet away. The City also demonstrated this concern and has had numerous resource evaluations done by various 
institutional and engineering firms with technical expertise in reservoir confirmation. Although the results to date have been very positive, there still remains a concern among existing well owners of the future effect of the project.

The City has been involved with the Klamath County Chamber of Commerce in an ongoing educational process to review existing data and reservoir estimates as to capacity. As of the date of this report, the community is still in the process of reviewing the reservoir data and making determinations as to the capability of the reservoir. Until a more positive attitude is demonstrated toward the pumping of geothermal fluids, the project is to proceed with the waste discharge collection system. Perhaps looking back, if there was any solution, the concerns demonstrated by the existing well owners may have been addressed in a more lengthy citizen participation process specifically involving the well owners. The city was involved in public information programs, with civic groups and in planning commission meetings.

\section{CONCLUSION}

Although the present anticlpated mode of operation of the system is somewhat different than the initial operation, there has been considerable data and experience learned from this project and there will be considerably more. The project has demonstrated the economic feasibility of construction of a geothermal heating district system, even at low density factors, such as the 14 bullding project, which has an anticipated payoff in 6.2 years. When in operation, the project will also provide valuable data and information on operational costs. The project has also served as a means for expanding the potential geothermal possibility to other areas. The City has been fortunate to receive two grants from the Department of Housing and Urban Development which also contain geothermal components. One of the grants, the Michigan 
Street project, involves using again, the waste discharge fluids which have previously been dumped and wasted, and circulating it through a 120 residential unit area. Overall, the project, although frustrating at times, has been successful in providing not only the City of Klamath Falls, but many other entities and also foreign countries with valuable information as to the economic and technical aspects of geothermal heating districts. 
PROJECT TITLE

Pagosa Springs Geothermal District Heating System

\section{PRINCIPAL INVESTIGATOR}

Worthe V. Crouse

Town Council Member

(303) 264-5698

PROJECT TEAM

Town of Pagosa Springs

Archuleta County

School District \#50-Joint

Coury and Associates, Inc.

\section{PROJECT OBJECTIVE}

The project objective is to demonstrate the engineering and economic feasibility for utilizing the Pagosa Springs natural hydrothermal resource for space heating.

\section{LOCATION DESCRIPTION}

Pagosa Springs, Colorado

60 miles $(97 \mathrm{~km})$ east of Durango, Colorado

Population: 1500

Area Activities: Ranching, lumbering, and tourism/recreation

RESOURCE DATA

Well depth

Date complete

Completion technique

1. Wel thead temperature

Flowrate

\begin{tabular}{ll}
$-\frac{\text { PS }-3}{300 \mathrm{ft}(91 \mathrm{~m})}$ & \multicolumn{1}{c}{ PS -5} \\
$7 / 2 / 80$ & $275 \mathrm{ft}(84 \mathrm{~m})$ \\
Open hole & $7 / 31 / 80$ \\
$131^{\circ} \mathrm{F}\left(55^{\circ} \mathrm{C}\right)$ & Open hole \\
$600 \mathrm{gpm}(38 \mathrm{l} / \mathrm{s})$ & $1480 \mathrm{~F}\left(64^{\circ} \mathrm{C}\right)$ \\
for $12-\mathrm{hr}$ test & $1200 \mathrm{gpm}(76 \mathrm{l} / \mathrm{s})$
\end{tabular}

Summary: The geothermal resource in Pagasa Springs has been used since the early 1900's. Nearly 30 wells have been drilled for heating and recreation purposes. These wells are drilled to depths of less than 500 feet $(152 \mathrm{~m})$ and produce waters ranging in temperature from $130^{\circ} \mathrm{F}$ to $170^{\circ} \mathrm{F}\left(54^{\circ} \mathrm{C}\right.$ to $\left.77^{\circ} \mathrm{C}\right)$. The hydrothermal. fluids are produced from a Dakota Sandstone aquifer. 
SYSTEM FEATURES

Application:

Heat load (design):

Yearly utilization (maximum):

Energy replaced:

Facility description:

Disposal method:
District heating

$27 \times 10^{6} \mathrm{Btu} / \mathrm{hr}$ (7.9 MW)

$28.6 \times 10^{9} \mathrm{Btu} / \mathrm{yr}$ (0.96 MW-yr)

Natural gas- $-40.8 \times 10^{6} \mathrm{cu} . \mathrm{ft} / \mathrm{yr}$

9 public buildings, 54 businesses, 63 residences, and designed for future expansion

The State of Colorado has agreed to discharge of the geothermal fluid to the San Juan River

Summary: The district system will provide heating for users located a long U.S. Highway 160 . For the proposed closed distribution system, two independent loops have been designed. The initial system will utilize $900 \mathrm{gpm}(57 \mathrm{l} / \mathrm{s})$ but will be capable of expansion to $1800 \mathrm{gpm}(113 \mathrm{l} / \mathrm{s})$.

STATUS

Construction and installation of the system was completed in October 1981. Initial acceptance tests were performed and completed during October-December 1981. The two geothermal system production wells have not received their final water production permits from the Colorado State Water Engineer. This fact precluded the Town's final startup and use of the system for the 1981-1982 heating season. Efforts are currently in progress to resolve the remaining permitting issues and to achieve final startup, testing, and operation of the system for the 1982-1983 heating season.

\section{SYSTEM DESCRIPTION}

Heat energy from geothermal waters is transferred to circulating waters in an independent distribution system. This closed distribution system consists of two separate loops, one for each side of town. This design feature provides the flexibility to shut off either loop in the event of required pipel ine maintenance, and it facilitates additional expansion in future years. The installed piping system and the control system are shown schematically in Figures 1 and 2.

\section{INSTITUTIONAL, CONSTRUCTION, AND OPERATIONAL PROBLEMS AND SOLUTIONS}

The most significant problem arising amid the Pagosa Springs system initial operation is institutional in nature rather than technical. To date, the two geothermal system wells have not received their final water production permits from the Colorado State Water Engineer's office. During the course 
of the project development, the Pagosa Springs city management, along with the project's engineering consultant team, continuously communicated with Colorado $0 i 1$ and Gas Commission officials and the State Water Engineer's office regarding the water rights issue. Lack of definition with respect to State agency regulation and decision-making authorities have complicated the process. Efforts are currently in progress to resolve this important issue such that the system can operate at design capacity during the coming heating season.

Several operational problems were also noted during initial startup and acceptance testing in late 1981. The first problem related to construction techniques used in laying the trunkline distribution piping. The trunkline piping is of large-diameter asbestos-cement construction; large o-rings provide the seal between the indiyidual pipe sections. During construction, certain of the o-rings either were damaged or were not sealed properly due to "stabbing methods" used to bring the pipe sections together. The resulting poor seal was soon apparent in the pressurized pipeline testing, where high leakage was immediately noted. The contractor then was required to identify and correct the faulty joints prior to system acceptance.

A second problem related to pressure fluctuations in the system. During initial operations, pressure gauges recorded a continual upward creep in the distribution and collection system pressures Ultimately, the pressure relief valves, which are preset at $150 \mathrm{psi}(1034.2 \mathrm{kPa})$, activated automatically for system protection. Review of the problem, coupled with field inspection, indicated that control valves, which have both flow and, indirectly, pressure maintenance functions, had not been installed per design requirements. This problem is currently being corrected.

Other smaller operational problems included the delivery and installation of pumps with certified curves that lacked proper packings. Also, a wire strainer located in the line from the geothermal wells to the plate heat exchanger is collecting considerable shale from the well-production flows. Originally, a manual wash cleaned the screen. In the future, this will be changed to an automatic wash conducted at intervals of one to two hours, or as needed.

Two final items are also worthy of mention. First, with the startup of any district heating system, consumers who have been approved for hookup to Y the system will not all physically tie into the system at the same time. Until the user actually ties in, no energy is used. Reasons for delays in hooking up to the completed system include personal and business financing considerations and delays in consumer equipment installation. Once the main geotherma 1 system is complete, however; revenues must be forthcoming to cover operating and maintenance expenses and to retire the capital debt. Therefore, once the system is operational, Pagosa Springs will be billing a fixed fee to customers who have contracted to hook up but who have not done so. If the customer refuses payment of this "access" charge, their "access" to the system may be given to a different party.

Finally, a continuing public information effort will be required at Pagosa Springs in future months. Public fears of general subsidence, or of the system affecting the historic natural springs in the town still persist.

An extended successful operating experience will do much to alleviate these important perceptions. 
The operational experience presented here is limited due to the water rights restrictions discussed previously. Additional judgments regarding equipment performance, water chemistry considerations, and consumer acceptance will be forthcoming as the system establishes an extended operating history.

\section{SCHEDULE}

The wells required for the project were completed in the summer of 1980 . The final design was completed in December 1980, and construction and installation of the system were completed in October 1981. Final startup and operation of the system are now scheduled for early fall 1982, and in time to serve the 1982-1983 heating season. A schedule of major completed and planned events is presented below.

1. Production well completion:

Summer 1980

2. Final Design completion:

3. Bid documents:

4. Construction contracts: December 1980

5. Construction: Apri1 1981 June 2, 1981

6. Initial acceptance testing: $\quad$ October-December July-October 1981

8. Final startup, testing, and system operation:

August-September 1982

\section{PROJECT COSTS}

Project Expenditures to Date-_-_._. $\$ 1,364,000$

DOE Share to Date-_.

Participant Share to Date-_._. * Includes $\$ 115,500$ of existing facility credits

\section{LESSONS LEARNED}

1. In Western United States regions, the water rights issue is highly visible and extremely important to the public. Since geothermal energy is a developing energy source with new implications for water use patterns, the regulatory authority governing water pemitting has not always been clearly identified. Rigorous efforts should be extended to insure the successful and timely resolution of permitting issues.

Keeping State agencies and local government bodies informed on the progress of the project, and particularly about well drilling, is of great value in assisting various permitting and approval requirements.

2. Predicting the existence of geothermal fluid underground, and especially quantification, is not reliable even in close proximity to existing wells. It seems the only dependable way to determine the existence of, and to quantify, geothermal sources is by means of test holes.

In our project, a new well located only 30 feet from a previously drilled test well produced fluid $10^{\circ} \mathrm{F}$ cooler than had been obtained from the test 
well at comparable depth. A second new well located 350 feet southwest of the first one did not produce fluid quantity or temperature comparable to the first new we1l, nor as expected from geological analysis of the substrata. The well could not be used and was cemented up. A third new well located 180 feet east of the first one, and about 30 feet south of an existing old well, produced much greater quantity of fluid than either of them, and $17^{\circ} \mathrm{F}$ hotter and at a depth considerably less than predicted by geological analysis of the substrata.

3. Drilling geothermal wells, particularly artesian wells, presents problems and situations not encountered in usual water well drilling. This applies not only to the temperatures and pressures involved but also to the subsurface strata which may have been affected by the geothermal conditions. Anomalies from usual geologic situations should be expected.

4. Keeping the public informed of project progress is important for successful acceptance, and to minimize erroneous information and rumors. One person should be designated to communicate with the media and the public on a regular basis.

5. If possible, a local contractor with interest in the project should be used. Since the contractor's reputation will be under close scrutiny, it is likely he will do a better job.

Extensive background checks should be made on all contractors by contacting the owner of their two or three most recent jobs. Past reputation may not always be accurate.

PAGOSA SPRINGS PON REPORTS

(Cooperative Agreement No. DE-FC07-79ET27030)

1. Garing, Kenneth L., Direct Utilization of Geothermal Energy for

Pagosa Springs, Colorado, Semi-Annual Progress Report, June-December 1979, Report ID0-7031-1, Contract No. DE-FC07-79ET27030.

2. Hydrosciences, Inc., Geohydrological Analysis of the Geothermal Reservoir, Pagosa Springs, Colorado, Cooperative Agreement No. DE-FC07-79ET27030, October 18, 1979.

3. Coury and Associates, Inc., An Environmental Report on the Construction and Operation of a Geotherma 1 District Heating System in Pagosa Springs, Colorado, Revision 1, Contract No. DE-FC07-79ET27030, January 1980.

4. Coury and Associates, Inc., Chaffee Geothermal, Ltd., and Hydrosciences, Inc., Geothermal Resources Report, Pagosa Springs, Colorado, Contract No. DE-FC07-79ET27030, January 1980.

5. Coury and Associates, Inc., Direct Utilization of Geothermal Energy for Pagosa Springs, Colorado, Preliminary Design Report, Contract No. DE-FC07-79ET27030, February 1980.

6. Coury and Associates, Inc., Direct Utilization of Geothermal Energy for Pagosa Springs, Colorado, Final Design Report, Contract No. DE-FC07-79ET27030, September 1980. 
7. Chaffee Geotherma 1, Ltd., Geothermal Drilling Activities, 1980, Contract No. DE-FC07-79ET27030, November 1980.

8. Hydrosciences, Inc., 1980 Hydrological Testing Program at Geothermal Production Wel1s PS-3 and PS-5, Pagosa Springs, Colorado, Contract No. DE-FC07-79ET27030, February 10, 1981. 


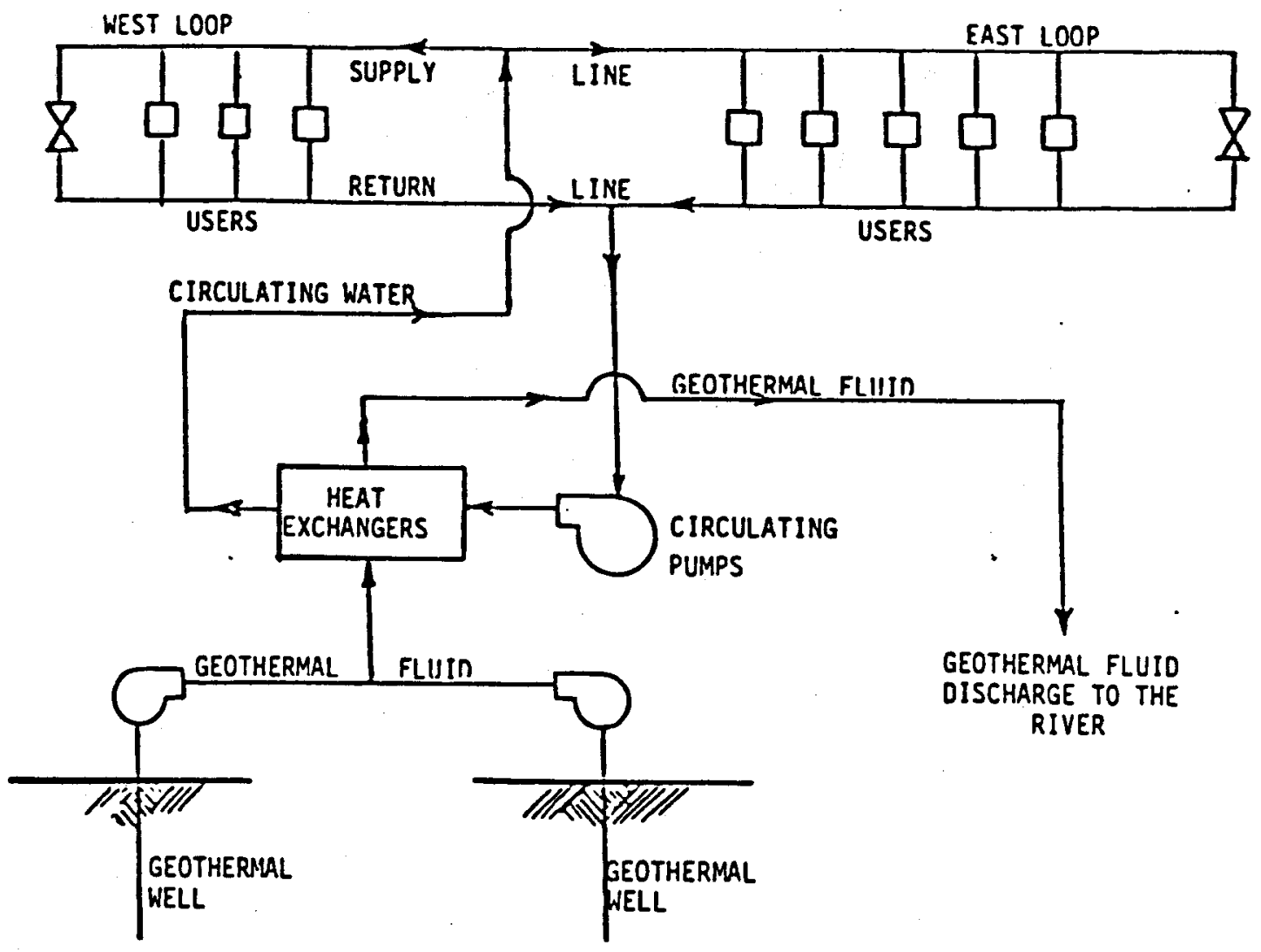

Figure 1. Schematic Diagram of the Pagosa Springs Geothermal Heating System

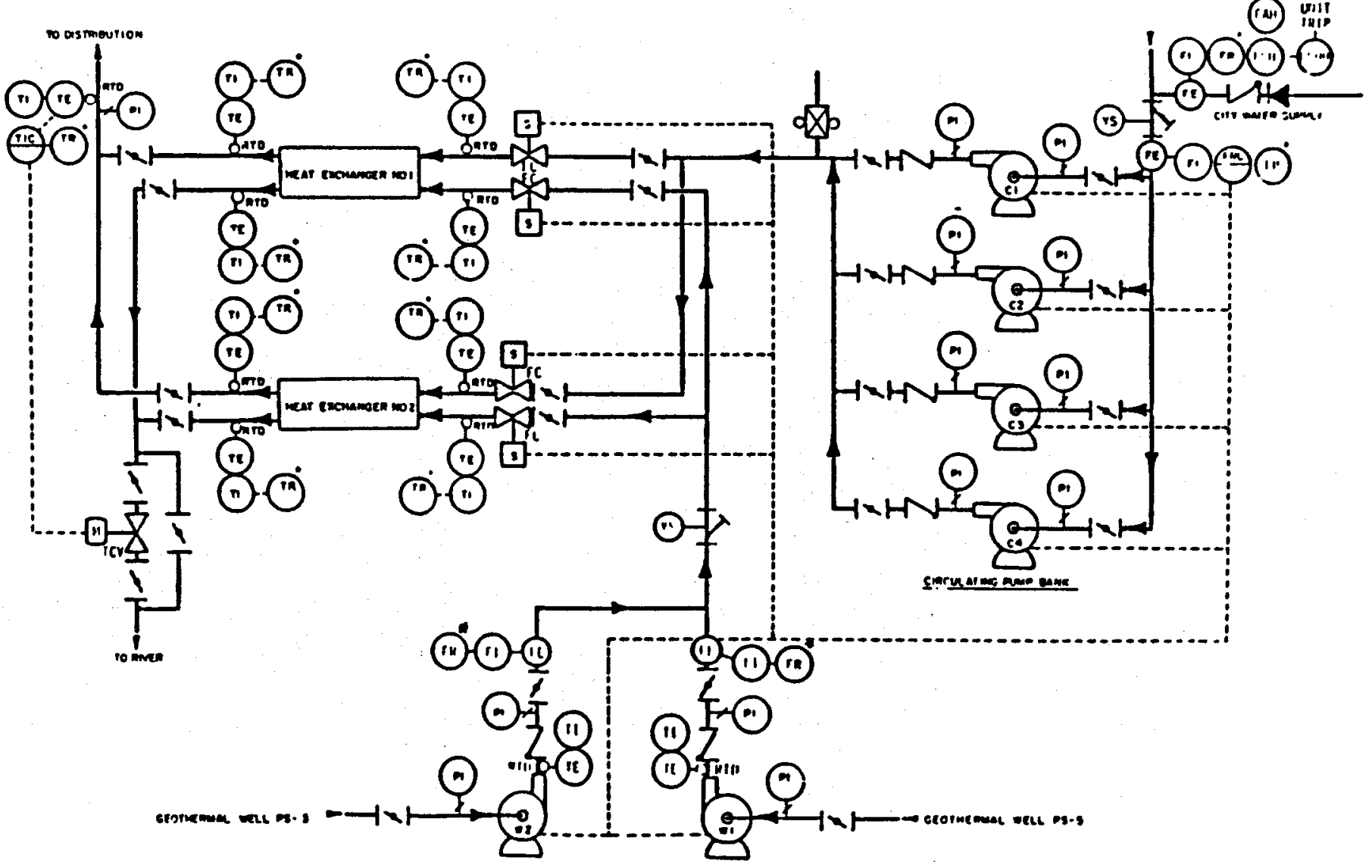

Figure 2. Pagosa Springs System Instrumentation and Control Schematic

.45 
THIS PAGE BLANK 
UTAH STATE PRISON

DIRECT UTILIZATION OF GEOTHERMAL ENERGY

FIELD DEMONSTRATION

AT

CRYSTAL HOT SPRINGS

GEOTHERMAL DIRECT HEAT APPLICATION PROGRAM

SEMI-ANNUAL REVIEW MEETING

- LAS VEGAS, NEVADA

AUGUST $5-6,1982$

CRAIG HIBBERD

Project Director

CASE, LOWE, AND HART

Design Engineers

$\mathrm{CH} 2 \mathrm{M} \mathrm{HILL}$

Preliminary Design Engineers
LEE HATHON

Design/Construction Manager

\begin{abstract}
MORRISON-KNUDSEN
30 Day Flow Test

Resource Consultants
\end{abstract}


DFCM061682CH

4415-2

$1 \quad$ PROJECT BACKGROUND

In July, 1978 the Utah Energy Office, on behalf of the State of Utah, submitted a successful proposal to the Department of Energy (DOE) in response to the Program Opportunity Notice (PON) for Direct Utilization of Geothermal Energy Resources.

In December 1981 the project was turned over the Utah State Division of Facilities Construction and Management for Resource Assesment, Final Design and Construction. The original proposal was to develop the Crystal Hot Springs geothermal resource located on private property adjacent to the Utah State Prison at the southern end of the Salt Lake Valley. The objective of the PON was to demonstrate the economic and technical feasibility of providing sufficient geothermal water for use in a variety of direct applications at suitable sites within the Utah State Prison complex. A geothermal well, heat exchange system, and injection disposal well were proposed to form the initial demonstration of providing geothermal water for space heating and domestic water heating for the minimum - security facility at the Prison.

Consisting of dorms, offices, a gymnasium, and a cafeteria, the 72,000 square foot minimum security facility was considered a good candidate for retrofit to geothermal energy for three reasons.

1. Due to its size and function, the facility consumed a large portion of the energy used at the Prison

2. The minimum security facility's location as the nearest major prison building to the Crystal Hot Springs resource; a distance of only 400 meters

3. The existing building's space heating system was a hot water system and was considered to be a relatively easy retrofit for a geothermal heating system.

The initial demonstration of providing the minimum security facility with space and hot water heating was intended to form the nucleus of a system which potentially could be expanded to provide the bulk of the heating requirements for the entire Prison.

The Crystal Hot Springs geothermal system is a deep convective system located at the eastern margin of the Basin and Range physiographic province. The thermal springs are located north of an east-northeast trending horst that is perpendicular to the structural trend of wasatch Front grabens. The horst, known as the Traverse Range, consists of 
DFCM061682CH

4415-3

highly fractured mid-Paleozoic quartzites and tertiary volcanics. Meteroic water enters the system in the adjacent ranges, circulates to depths of $3 \mathrm{~km}$, and is heated. The termal fluids return to the surface along steeply dipping range front faults that bound the northern flank of the range. The termal springs issue between two such faults that are buried beneath Tertiary and Quatenary age valley fill deposits. Highly fractured quartzite beneath the valley fill act as a near-surface reservoir for thes thermal water that is being targeted for development.

The surface expression is defined by several hot water spring discharges contained within a 70 acre area. At the center of the Crystal Hot Springs resource area springs issue to the surface through alluvium that is approximately 80 feet thick.

\section{$2 \quad 30-D A Y$ WELL TEST}

Preliminary data from the Utah Prison Geothermal Well Test indicate a protential of supplying significant energy to the Utah Prison complex. The test was initiated on June 15 at a constant artesian flow rate of $300 \mathrm{gpm}$. The well was flowed at a constant rate of $300 \mathrm{gallon} / \mathrm{minute}$ for 20 days then increased to 600 gallons per minute. This preliminary analysis of trends within the production well, USP/TH-l, and two observation wells, Utah Roses production and US Forest Service, covers only the $300 \mathrm{gpm}$ portion of the test.

The production well indicates a steady trend of pressure decline of approximately $0.4-0.5$ psi per long cycle. The scattering of points was the result of $\mathrm{CO}_{2}$ flashing within the well bore causing a gas lift with resultant surging (Figure 1).

Data from the Utah Roses production well which was used as an observation well indicates a stabilizing of pressure declines at 50 hours into the test. Two major boundaries can be seen from this data. Th first one hour into the test and the second 15 to 20 hours into the test (Figure 2 ).

The U.S. Forestry Observation well also shows a pressure decline but with stabilization of drawdown occuring 200 hours into the test (Figure 3 ). Several boundaries can be detected in the curve such as at 19 hours and 200 hours into the test. The scattering of points in the last 100 hours of the test indicates a stabilization of the drawdown. 


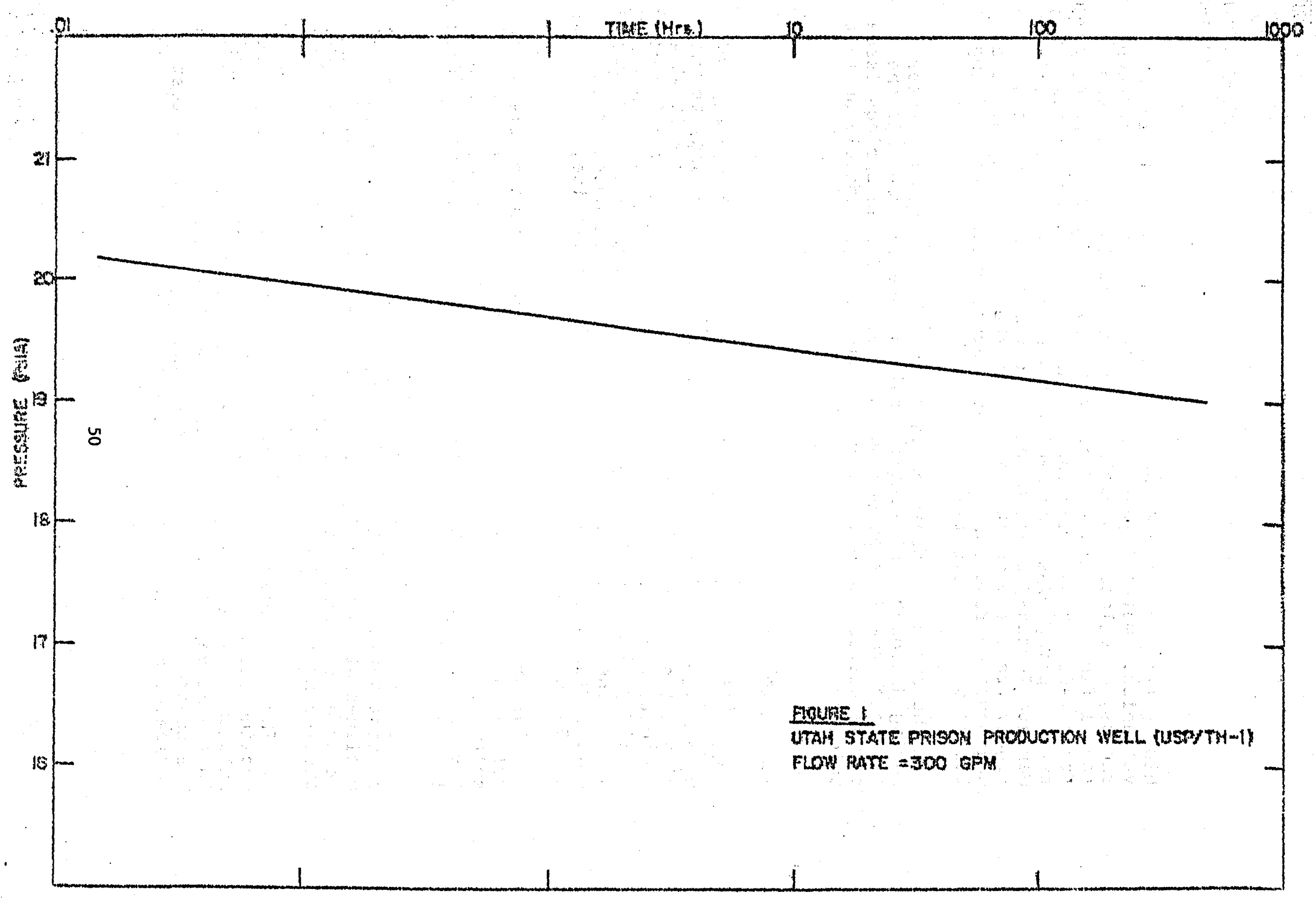




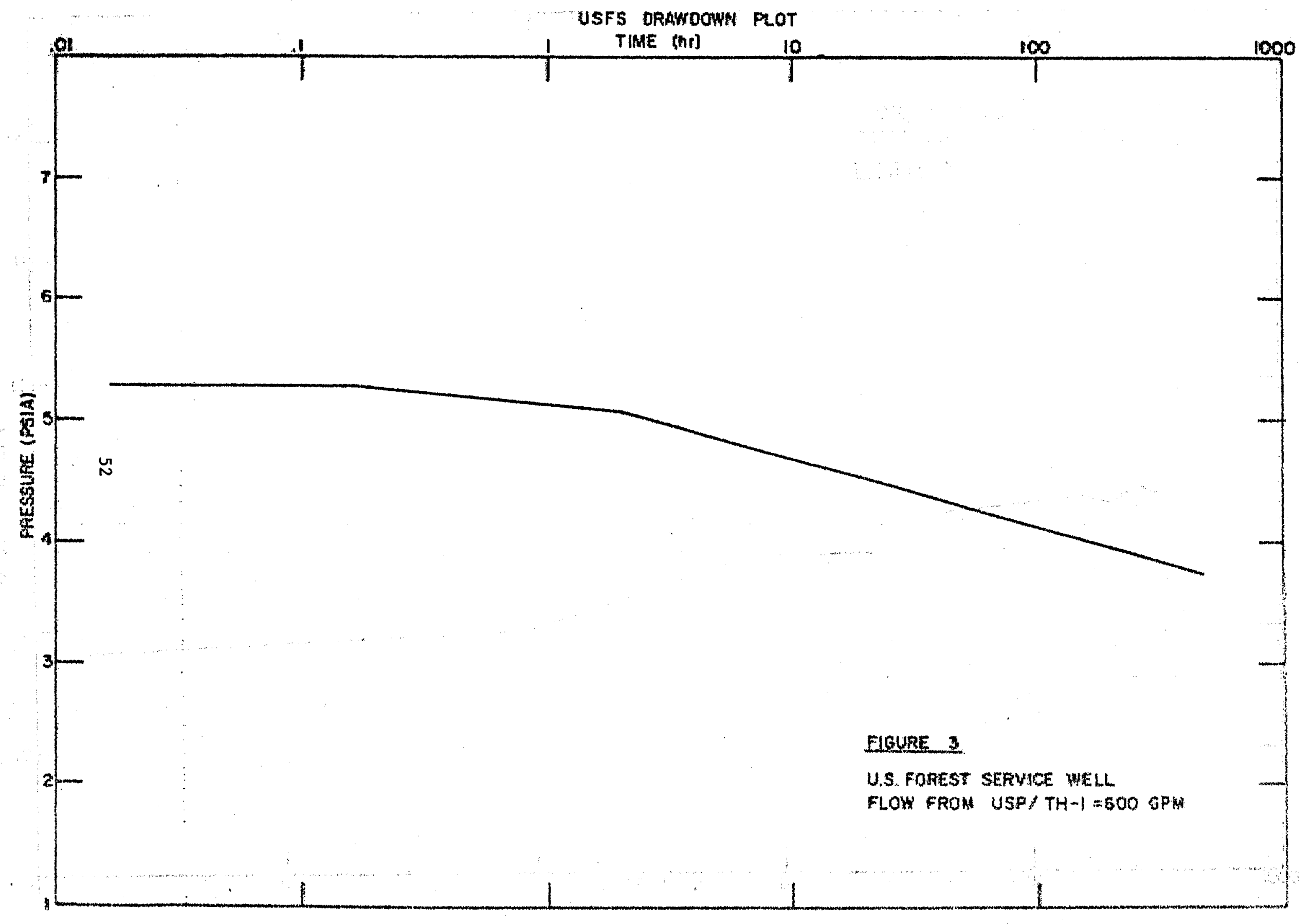


FIGURE \#4

WATER ANALYSES, UTAH STATE PRISON WELL THI

\begin{tabular}{lrrrrr}
\hline SAMPLE NO & 1 & 4 & 5 & 6 \\
\hline Temperature $\left({ }^{\circ}\right)$ & 82 & 81 & 82 & 82 \\
PH & 6.65 & $6 / 9 / 82$ & $6 / 22 / 82$ & $6 / 29 / 82$ & $7 / 6 / 82$ \\
Collection Date & $6 / 6.65$ & 6.4
\end{tabular}

\section{CONCENTRATIONS (ppm)}

$\mathrm{Na}$

$\mathrm{K}$

$\mathrm{Ca}$

$\mathrm{Mg}$

$\mathrm{Fe}$

$\mathrm{SiO}_{2}$

Li

B

Total Dissolved Solids

$\mathrm{SO}_{4}$

$\mathrm{Cl}$

$\mathrm{F}$

$\mathrm{HCO}_{3}$
408

64

141

32

0.35

$\because 52$

1.48

1.5

1898

66

752

2.6

428

$6 / 22 / 82$

$9 / 82$

$7 / 6 / 82$

Geothermometers $({ } \mathrm{C})$

T (Quartz-Cono)a

$T(\mathrm{Na}-\mathrm{K}-\mathrm{Ca}-\mathrm{Mg})^{\mathrm{b}}$

70

74

75

74

81

81

81

82

a. Calculated by the method of Fournier, 1977

b. Calculated by the methods of Fournier and Truesdell (1974) and Fournier and potter (1979). 
Since the value of $C$ for steps 2 and 3 is greater than the value of $C$ for steps 1 \& 2 , this indicates that the well production is lower than the well is capable of yeilding.: The average value of $C$ is about $4.59 \sec ^{2} / \mathrm{ft}^{5}$. shown:

The well loss at the 300 gpm pumping rate was computed as

$$
S x=2.04^{\prime}
$$

The total evaluated drawdown in the well at $300 \mathrm{gpm}$ was 8.03 feet. Thus, well loss amounted to about 27 per cent of the total drawdown in the production well for a pumping rate of $300 \mathrm{gpm}$.

In conclusion, it appears two major factors may account for the well loss. The method of completion with a slotted liner has not allowed for enough openings compared to total surface area of the pipe. The second factor accounting for well loss is a result of the $\mathrm{CO}_{2}$ flashing in the well bore causing a gas lift condition to occur. The flashing appeared to have increased with time probably as a result of well bore heating.

Well Loss from Step Drawdown Testing:

The initial evaluation of the production well requires a determination of well losses. Well loss may be calculated by the following equation (Jacob, 1946b):

$$
S_{W}=C^{2}
$$

where:

$$
\begin{aligned}
& S W=\text { Well loss, in } i t . \\
& C=\text { Well loss constant, in } \sec ^{2} / \mathrm{ft}^{5} \\
& Q=\text { Discharge, in cubic feet per second (cfs) }
\end{aligned}
$$

The value of $C$ in this equation is computed from the data collected during a "step-drawdown" test, in which the well is operated during successive periods at constant fractions of full capacity. This value is computed from the following equation:

$$
c=\frac{\left(\Delta S_{1} / \Delta Q_{1}\right)=\left(\Delta S^{i}-1 / \Delta Q_{i-1}\right)}{\Delta Q_{i=1}+\Delta Q_{1}}
$$

For successive drawdown steps this equation is rewritten as:

$$
c=\frac{\left(\Delta S_{2} / \Delta Q_{2}\right)=\left(\Delta S_{1} / \Delta Q_{1}\right)}{\Delta Q_{2}+\Delta Q_{3}}
$$


On June 15 th a step drawdown test was conducted on the utah State Prison Geothermal Production we11. The increments of discharge or step rates were $100 \mathrm{gpm}, 200 \mathrm{gpm}$ and $300 \mathrm{gpm}$. The data produced from this test was substituted into the above step equations and produced the following values of $C$ :

$\begin{array}{ll}\text { Steps } 1 \& 2 & C=1.84 \sec ^{2} / \mathrm{ft}^{5} \\ \text { Steps } 2 \& 3 & C=7.33 \mathrm{sec}^{2} / \mathrm{ft}^{5}\end{array}$

Because of the stabilizing of the drawdown at $300 \mathrm{gpm}$ and the need to stress the reservoir to obtain a full reservoir characterization, it was decided to increase the flow of the well to 600 gallons per minute. This increased occurred on July 6 and was continued at this rate until July 19 , when well was shut in and a recovery test conducted. Final reservoir characterization and confirmation will be established upon completion of the recovery portion of this test.

Geothermal Water Description:

The Utah State Prison Well (TH 1) taps a low temperature geothermal reservolr. "The thermal water, flowing under artesian pressure, has a measured surface temperature of 81 to $82^{\circ} \mathrm{C}$. The reservoir water is near-neutral sodium chloride in character and slightly saline, with a dissolved solids content on the order of 1800 ppm (Figure 4 ). Predicted subsurface reservoir temperatures of 81 to $82^{\circ} \mathrm{C}$ calculated with the $\mathrm{Na}-\mathrm{K}-\mathrm{Ca}, \mathrm{Mg}$ corrected, geothermometer and 70 to $750 \mathrm{C}$ calculated with the quartz, conductively cooled, geothermometer suggests that the thermal reservoir tapped by this well is probably not much hotter than $820 \mathrm{C}$.

\section{PRELIMINARY DESIGN}

The preliminary design was submitted on Sept. $30,1981$. The preliminary included the following:

A. Adjusted annual consumption for space heating and domestic hot water combined is $16,500 \times 106$ BTU.

B. Mechanical system to be designed for Geothermal heat component to supply $76 \%$ of total design capacity due to assumptions that the well could not produce:more than an average $100 \mathrm{gpm}$ over 8 month heating seasons.

C. Production pumping system to consist of a $50 \mathrm{HP}$, variable-speed, vertical turbine lineshaft pump set at $518 \mathrm{ft}$. The pump would deliver $200 \mathrm{gpm}$ (2) $135 \mathrm{psig}$ to the inlet of 7200 feet of geothermal supply and disposal fluid piping. The nigh pressure is required to maintain a minimum of $110^{\circ}$ psig throughout the 
geothermal transport system to preclude the evolution of $\mathrm{CO}_{2}$ from the geothermal fluid. As the pressure of the geothermal fluid decreases so does $\mathrm{CO}_{2}$ solubility allowing the $\mathrm{CO}_{2}$ to come out of solution and form $\mathrm{C}_{a} \mathrm{C}_{03}$ scale throughout the system.

D. Transmission pipeline system: consists of a $3,200 \mathrm{ft}$. long primary geothermal fluid loop from well heat to building mechanical rooms and rturn. This piiping was recommended to be epoxy-lined asbestos cement or fiberglass - reinforced plastic.

E. Heat Exchange System: would consist of plate heat exchangers located in the existing building mechanical rooms and hooked in series with the existing steam/hot water heat exchangers. The geothermal fluid "cascades" through the space heating heat exchanger first, then the domestic hot water exchangers. The heat exchangers were designed for a $5^{\circ} \mathrm{F}$ approach and a $37.5^{\circ} \mathrm{F}$ geothermal fluid temperature drop.

F. Once returned to the wellnead, the fluid still pressurized, will flow 4,000 $\mathrm{ft}$. to the Jordan River through epoxy-lined asbestos cement or fiberglass reinforced plastic pipe. A cooling pond $50^{\prime} \times 65^{\prime} \times 3^{\prime}$ and spray nozzles will cool the geothermal fluid to within $35^{\circ} \mathrm{F}$ of the river temperature.

4 Final Design

During the early design development stage of final design the following modifications to the preliminary design are being considered:

a. Plate heat exchangers to be located at the well head instead of building mechanical rooms. A primary hydronic loop will transport heat to the mechanical rooms. This saves the pipe friction loss associated with transporting pressurized geothermal fluid to the building and back ( $3200 \mathrm{ft}$.$) .$

b. Flowing the geothermal system unpresurized is being considered. Five reasons to support this consideration are:

1. Preliminary well flow aata indicated the well will flow artesian at $200 \mathrm{gpm}$, with 7 psig wellhead pressure.

2. Pumping costs for electricity could be lowered substantially 
3. Capital costs for well pump could be deleted.

4. Although the water chemistry is different. A similar system is in operation at Klamath Falls Oregon.

5. The system design and operation would remain simple.

The unpressurized system would allow the $\mathrm{CO}_{2}$ gas to vent in a settling/storage tank from which geothermal water would be drawn for the plate heat exchanger. The system would be designed for easy retrofit to a pressurized pump or $\mathrm{CO}_{2} 11 \mathrm{ft}$ system if the well plugs or the plate heat exchangers develop deposits prematurely.

\section{PROJECT SCHEDULE}

Final Design Review

Advertise Bids

Contractor Selection

Construction Completed

Completion of Monitoring
September 30,1982

October 15, 1982

November 15, 1982

March 15, 1983

May 30,1984

\section{FACILITY RETROF IT}

Reports identified serious problems with the mechanical and control systems of the Minimum Security Facility. $\$ 91,000$ dollars was appropriated to retrofit these systems so they would better interface and compliment the new geothermal heat source. These modifications Include:

a. Reducing pumping capacity ( $800 \mathrm{gpm}$ to $200 \mathrm{gpm}$ ) of space heating hydromic loops in the building. This was accomplished by abandoning some loops and then balancing the remaining loops.

b. Retrofitting hydronic heating system with all new 2-way and 3-way control valves.

c. Installing new mixed air controlls in each of 11 fan rooms with outside air reset.

d. Abandon all existing space thermostats and replace with sensors in the return air ducts.

These improvements will lower the existing heating load and enhance the overall project. 


\section{FUTURE GEOTHERMAL AT STATE PRISON}

Preliminary 30 day flow testing results from the geothermal well indicate the reservoir may be capable of 2,000 gpm flows.

To develop this resource the state has funded a Technical Energy Audit of the entire Prison Complex. The audit will identify other buildings that will benefit from conversion to the geothermal heat source. If these buildings are connected to geothermal source, it is expected that the primary hydronic loop from the well head will be oversized to accommodate this expansion.

Currently the Prison complex is spending over $\$ 350,000$ annually for natural gas. This geothermal reservoir may be capable of substantially replacing natural gas as a primary heating source at the state Prison.

\section{REFERENCES}

Fournier, R. 0., 1977, Chemical geothermal and mixing models for geothermal systems, in proceedings of the International Atomic Energy Agency Advisory Group on the Applications of Nuclear Techniques to Geothermal Studies, Pisa 1975: Geothermics, Special Issue, v.5, p. 4l-50.

Fournier, R.0., and Potter, R.W., II, 1979, Magnesium corretion to the $\mathrm{Na}-\mathrm{K}-\mathrm{Ca}$ chemical geothermometer: Geochimica et Cosmochimica Acta, v. 43, p. 1543-1550.

Fournier, R. 0. and Truesdell, A. H., 1974, Geochemical indicators of subsurface temperature - Part 2, Estimation of temperature and fraction of hot water mixed with cold water: Journal of Research United States Geological Survey, v. 2, $p$. 263-270. 
REVIEW OF D.O.E. GEOTHERMAL DIRECT

HEAT APPLICATIONS PROGRAMS PROJECTS

LAS VEGAS, NEVADA

PROJECT SUMMARY

\section{Project Title:}

Field Experiments for Direct Uses of Geothermal Energy

Elko, Nevada

Principal Investigator:

ELKO HEAT COMPANY

Mr. James Meeks, Sr., President

Project Engineer

CHILTON ENGINEERING, CHARTERED

Mr. Michael W. Lattin, P.E., Project Manager

\section{Resource Description:}

The Elko Heat Company project will utilize low temperature (less than 200 F) goethermal fluids from the Elko Resource Area. This area has been classified as a Known Geothermal Resource Area (KGRA) by the U.S.G.S. The existence of the resource has been recognized in Elko for many years (as far back as the late $\left.1800^{\prime} \mathrm{s}\right)$. There are a number of surface expressions located in the southwest portion of the City. In the past, utilization of the resource has been limited to heating a spa (1ate 1800 and early 1900's), source of water for the Elko Municipal Swimming Pool until 1950, use as domestic hot water on a limited basis, and more recently, use as a heat source for a greenhouse growing a variety of vegetables.

These uses are utilizing one of the three surface expressions of the resource or shallow underground flow related to the surface expression.

The extent and location of the resource at depth had never been defined. In the past when drilling penetrated the hot underlying strata, drilling was stopped and the hole either plugged at the bottom or abandoned. Most of the drilling activity was in the search for supplies of cold water and every effort was made to avoid the geothermal resource.

The Elko Heat Company project made the first attempt to locate and define the underlying geothermal resource. This investigation consisted of running a series of shallow temperature gradient holes, geologic fault mapping of the area, and electrical resistivity and electromagnetic surveys. The work was completed by Geothermal Surveys, Inc. (GSI) from Pasadena, CA. 
The next phase of the resource assessment consisted of drilling four (4) test holes to depths between 600 and 1100 feet. These test holes exhibited the expected abnormally high downhole temperature gradient. What was considered the best test hole was abandoned at approximately 600 feet after the drill rig tipped over. The decision was made to attempt drilling a production well at this location.

The production well was completed in August, 1981 and was successful in tapping the resource. The well encountered what is reported to be a faulted fractured zone at $850^{\prime}$ which produced a geothermal fluid with a temperature of $180^{\circ} \mathrm{F}$. The well was artesian and flowed at over $500 \mathrm{gpm}$ with a shut in pressure of 51 psi. Flow from this well appears to be controlled by a complex faulting system.

Testing of the well has confirmed a reservoir of large capacity and proven reliability after more than 50 days of flow testing under artesian conditions.

It is felt that in the future additional wells can be completed and the capacity of these wells could be greatly increased if desired.

The water quality of the geothermal fluids from the Elko Resource is excellent and meets State and Federal requirements for drinking water. The type of fluid is indicative of a shallow and low temperature resource. The water quality analysis is shown in Table I below:

TABLE I

ELKO HEAT COMPANY

PRODUCTION WELL NO. I

WATER QUALITY ANALYSIS

Results in $\mathrm{mg} / 1$

\section{CONTAMINATE}

Arsenic

Barium

Cadmium

Chromium

Flouride

Lead

Mercury

Nitrate (As $N$ )

Selenium

Silver

T.D.S.
SAMPLED $12 / 1 / 81$

0.0078

0.78

0.0002

0.0021

1.8

0.0010

0.0001

0.05

0.001

0.0002 
TABLE I

WATER QUALITY ANALYSIS

(Cont'd)

CONTAMINATE

Hardness

Calcium

Magnesium

Sodium

Potassium

Sulfate

Chloride

Alkalinity

Bicarbonate

Carbonate Hydroxide

Iron

Manganese

$\mathrm{pH}$

Silica

Lithium
SAMPLED $12 / 1 / 81$

214

61

12

117

47

77

16

405

378

2

.26

01

6.7 units

59.2

0.35

Project Objectives:

The Elko Project is intended to demonstrate the feasibility of utilizing geothermal energy in a district heating type of application. The technical and economical feasibility will be demonstrated by three initial users utilizing the heat in three different conceptual heating applications. The Vogue Laundry, a commercial linen supply business, will utilize the water directly for wash water after softening. The Stockmen's Motor Hotel, a hotel/casino complex, and the Henderson Bank Building, a four story office complex, will utilize the water for space heating and heating of hot water.

The Stockmen's will utilize a heat exchanger to heat a closed hydronic loop. The Henderson Bank Bujlding will circulate the geothermal fluids directly through either the existing radiator system or the existing fan coils (presently utilized for building cooling). The planned system will displace $100 \%$ of the Stockmen's and Henderson's space heating and hot water requirements. Both systems are designed to take $165^{\circ} \mathrm{F}$ (minimum) water and discharge $115^{\circ} \mathrm{F}$ resulting in a $50^{\circ} \mathrm{F} \triangle \mathrm{T}$. 
The Vogue Laundry will utilize the geothermal fluid in place of existing city water supply, thus eliminating the need for heating City water at a temperature of between $55^{\circ}$ and $60^{\circ} \mathrm{F}$ to $160^{\circ} \mathrm{F}$.

The retrofitting of these three users results in approximately 25,000 million BTU's of conventional fuel being displaced. The displaced fuel is primarily natural gas which presently costs $\$ 5.20 /$ million BTU's. The building retrofitting design and construction is the responsibility of the end user. Elko Heat Company is committing only to provide geothermal fluid at the $165^{\circ} \mathrm{F}$ minimum temperature and at the quantities required by the end user.

It is anticipated that the end users will be on line by the fall of 1982. One year of monitoring of the system will take place at this time to determine the system efficiency.

Special Investigations:

Elko Heat Company has been involved in a number of tests and studies to confirm the reliability of the existing production well and to assist in materials selection for final design.

These tests included 50 days of flow testing to monitor reservoir performance, temperature, pressure and water quality, operation of a prototype heat exchanger, and corrosion and scaling tests. The flow tests were run not only to determine the capabilities of the Elko Heat Company well but also to study the potential for interference with other geothermal wells and springs in the area. There was no evidence of interference with these sources.

The long term flow tests were valuable in confirming the resource reliability and determining potential interference with other sources. During the flow test, a leak in the well bore was located, that was successfully sealed off at a later date. It was also noted that temperature fluctuated, depending on rate of flow and duration of flow, between $173^{\circ} \mathrm{F}$ and $178^{\circ} \mathrm{F}$. It is felt this temperature fluctuation was related to the leak in the well bore.

All test results to date indicated that the fluid is very "mild" and no special problems in materials selection are anticipated. One factor encountered was that system pressures have to be maintained above 10 pounds per square inch to keep the carbon dioxide gas in solution to avoid bicarbonate ion precipitating out as calcium and magnesium carbonate.

\section{System Design:}

The geothermal energy distribution system has been designed and is scheduled to go out to bid during the month of July. The estimated cost of the system is $\$ 525,000$. The well head equipment consists of a deep well line shaft pump set at 150 feet and equipped with a variable speed drive, miscellaneous piping and valving and a pump building. 
The well head system operates under artesian flow conditions up to $200 \mathrm{gpm}$ and under pumped flow at ranges between 200 and $600 \mathrm{gpm}$. The system is controlled by sensing changes in pressure in the discharge piping.

The distribution system consists of 4000 feet of $10^{\prime \prime}$ and 8 " diameter asbestos-cement supply and return pipe. Approximately 2000 feet of the supply pipe will be insulated "Temptite" pipe to avoid excessive temperature losses, due to ground moisture conditions. The remainder of the system is uninsulated.

The system provides for conveying high temperature supply water (1650 minimum) to the initial users who will either utilize the water directly or extract heat and dispose of the reduced temperature water in the return line. In the future, an effort will be made to "cascade" (to find users with lower temperature requirements who could use the $100^{\circ}$ to $110^{\circ} \mathrm{F}$ return water directly or in combination with a heat pump system).

The return fluids will eventually end up in a surface disposal pond where cooling will be provided through a spray nozzle system with the water either used by the City of Elko for irrigation or disposed of by infiltration/percolation.

The following figure I shows a schematic diagram of the piping and valving arrangement in the pump building.

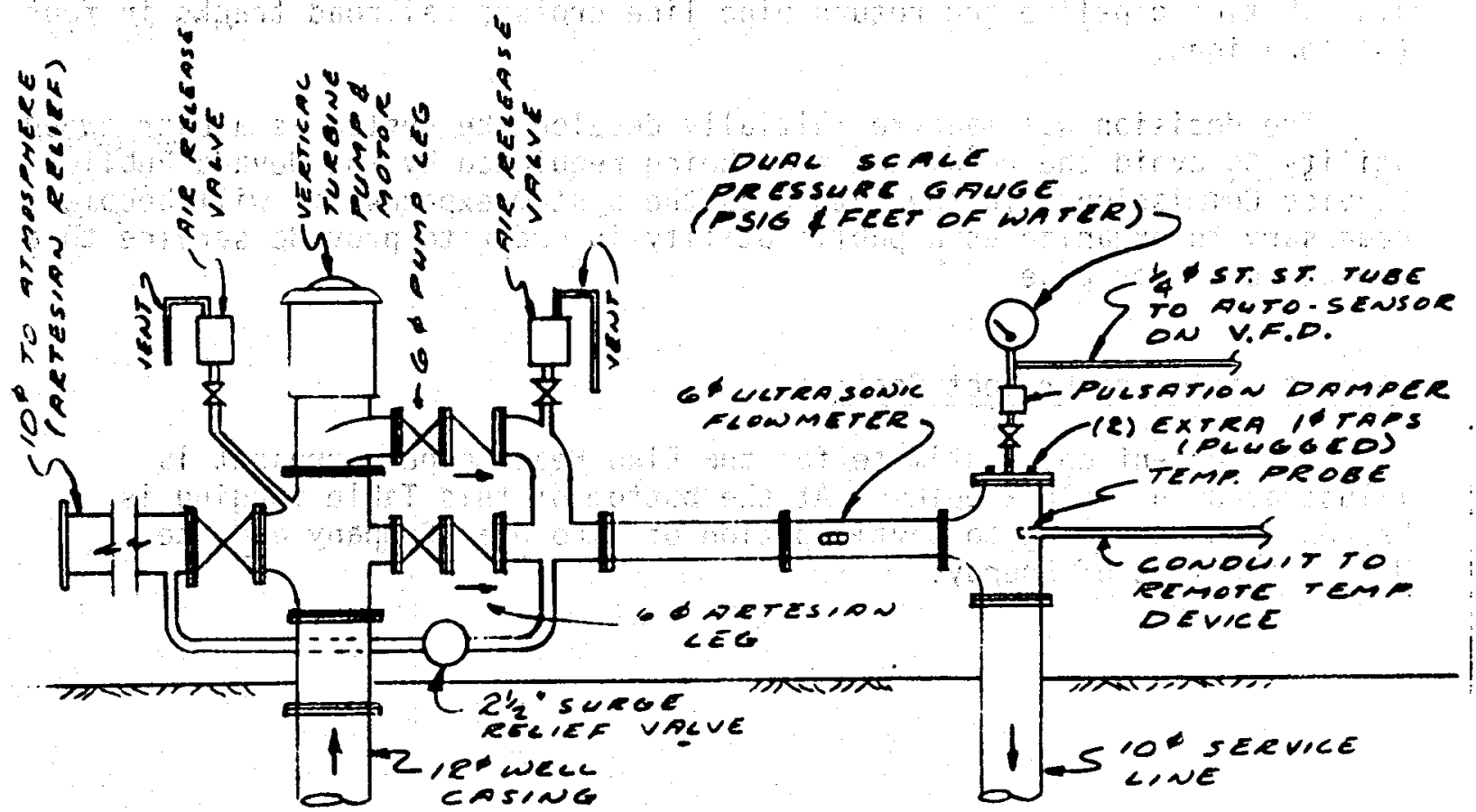

EQUIPMENT AT WELCHEAO

N.T.5. (SCACHAT,C)

$=10<\cos$

\begin{tabular}{|c|c|}
\hline ECNO & HEAT COMPONY \\
\hline & CHILTON ENGINEERING \\
\hline
\end{tabular}




\section{Legal and Procedural:}

The project as designed required an agreement between the city of Elko and Elko Heat Company to provide a pond for the disposal of spent fluids. The City of Elko was very cooperative in allowing Elko Heat Company to build this pond on their property. Disposal of spent fluids was a serious project concern and this agreement resulted in a relatively simple solution to the problem.

The question of water rights resulted in significant project delays. Under Nevada Law, a well cannot be drilled in the Elko groundwater basin without first obtaining a permit from the State Engineer. When the well location was finally confirmed, it was decided to accept a permit that contained terms calling for reinjection of spent fluids to the "source" or a non-consumptive use of the water.

The final design required a consumptive use of the fluid and therefore, a change in the permit terms. The change to a consumptive use is presently before the State Engineer who is expected to rule on the matter some time in July, 1982. The flow testing and monitoring program was utilized by Elko Heat Company to support the requested change.

It was necessary to acquire permission from the City of Elko, Western Pacific Railroad and Southern Pacific Transportation Company to construct facilities on their lands and/or in the vicinity of their facilities. The distribution pipeline and return pipe line crosses railroad tracks in four (4) locations.

The decision was made to initially develop the system as a user owned utility to avoid the requirement of being regulated by the Nevada Public Service Commission. In the future as the system expands, it will become necessary to organize as a public utility in order to provide service to a broader customer base.

\section{Current Estimated Project Cost:}

The current cost estimate for the Elko Heat Company project is illustrated in Table 2 below. At the bottom of this Table funding is broken down according to participation of Elko Heat Company and the U.S. Department of Energy. 
TABLE 2

ELKO HEAT COMPANY

TOTAL ESTIMATE PROJECT COST

ELKO GEOTHERMAL ENERGY PROJECT

I ENVIRONMENTAL REPORT

$\$ 12,235$

II RESOURCE ASSESSMENT

164,139

III PRODUCTION WELL DRILLING

150,000

IV CONCEPTUAL DESIGN

58,036

$\checkmark$ FINAL DESIGN

93,000

IV PROTOTYPE HEAT EXCHANGER TESTING

4,579

VII CONSTRUCTION MANAGEMENT

50,000

\section{SYSTEM FABRICATION}

Pump house and production

well equipping $\$ \$ 70,000$

Distribution system $\quad 410,000$

Effluent Disposal System $\quad 55,000$

Building Retrofitting $\quad 281,000$

TOTAL CONSTRUCTION

$\$ 816,000$

IX MISCELLANEOUS COSTS, PERMITS, LAND AND RIGHT-OF-WAYS,

LEGAL EXPENSE, ETC.

96,000

$X$ FINAL PROJECT MONITORING

AND EVALUATION

$\underline{21,445}$

ESTIMATED TOTAL PROJECT

COSTS:

$\$ 1,465,434$

DOE FUNDING AVAILABLE

$827,524(56 \%)$

ELKO HEAT COMPANY FUNDING

$637,910(44 \%)$ 
Lessons Learned:

Project permitting and licensing requirements should be fully investigated and evaluated early in the project. This project has encountered difficulty in securing adequate water rights and in developing an acceptable plan for disposal of spent fluids.

After developing and securing an adequate resource the question of disposal of spent fluids is the next most important question. Disposal alternatives considered included:

1. Reinjection to geothermal acquifer

2. Disposal by infiltration/evaporation

3. Discharge to local receiving water

4. Treatment and reuse as potable water

5. Reuse as agricultural or industrial process water

6. Discharge into sanitary sewer system

Because of the relatively good quality of the geothermal water a combination of alternatives 2 and 5 was selected.

The design of geothermal wells in unknown fields must be based upon sufficient data to insure proper construction. Elko Heat Company completed a well that was leaking hot water into a shallow cold water acquifer. Had it not been discovered, this condition could have resulted in a warming of the cold water acquifer and/or the development of springs or seeps in the vicinity of the well.

This leakage was occurring at a depth of 242 feet where an 8 " diameter liner was hung inside a 12" diameter. casing. This joint was sealed by "squeezing cement" into the annulus. This type of repair was very expensive, risks losing the well and results in the project being delayed.

Another problem encountered in the construction of the Elko Heat Company well was that the original design called for open hole completion from 542 feet to 852 feet. The production zone was determined to be located between 845 feet and 850 feet depth. The formation from 542 to 800 feet was unstable and bridging or plugging occurred in this area. This required installation of a $6^{\prime \prime}$ diameter blank liner from 242 feet to 820 feet.

Prior to completing a well in unknown fields a pilot or test hole should be drilled to determine formation types and whether or not the well will be artesian. If artesian conditions are present the non-productive formations encountered should be cased and cemented. After completion of the well flow testing, temperature and spinner loggings should be done. All unstable formations should be cased and perforated casing or well screens installed in the production zone if necessary. 
Another lesson learned is that it is very difficult to estimate project cost prior to determining the resource location. Elko Heat.Company anticipated drilling a well within 500 feet of the end users, but the well that was completed ended up over 3000 feet away from the nearest user, which resulted in a considerable increase in project cost.

Summary:

Because of the unknowns associated with this type of system, both cost estimates and time schedules have been under continual revision. There are many factors that influence the development of this type of system. The Elko Heat Company system has progressed to a point that the Board of Directors are now confident that the project can be completed in accordance with the original project objectives. 
THIS PAGE BLANK 
NAVARRO COLLEGE

P.0. Box 1170

Highway 31 West

Corsicana, Texas 75110

Telephone: 214/872-6501

PROJECT TITLE: Direct Utilization of Geothermal Heat in Cascade Application to Aquaculture, Greenhouse and Irrigation Systems

PROJECT DIRECTOR: Dr. Lary L. Reed, Executive Dean, Navarro College

PROJECT TEAM:

Prime Contractor: Navarro College, Corsicana, Texas

Project Coordinator: Environmental Aquaculture Services, Kenan Smith

\section{PROJECT DESCRIPTION}

In 1979, Navarro College drilled a geothermal production well (No. 1) completed to a depth of 2,664 feet which, through testing, was found to produce a flow rate of $315 \mathrm{gpm}$ at $1250 \mathrm{~F}$. In 1980, an injection well (No. 2) was completed and later tested to recelve fluid at the rate of approximately $60 \mathrm{gpm}$. Beginning December 1981, Navarro College started work to develop and implement a cascade system to fully utilize the medium temperature water for aquaculture, horticulture, and agriculture applications.

The final project design will reflect engineerling which causes the geothermal resource to heat a freshwater source through the use of a heat exchanger; the geothermal water will then be Injected back Into the earth at. the upper Woodbine level, and the heated freshwater will be used throughout the cascade system.

Once the freshwater has been heated through a heat exchanger, it w111 flow into two $1 / 4$ acre aquaculture ponds used for the propagation of prawns 
and trodical fish; warm effluents from the aquaculture operation will be collected and piped through a greenhouse operation to maintain suitable space and soil heating for the horticulture phase; the effluent will then flow into a $11 / 2$ acre collection reservoir where fingerling channel catfish will be placed to determine growth rates and yield relative to the economics of farm pond management. Excess effluent water collected in the reservoir w111 be disposed of by means of an irrigation system whereby approximately 25 acres of land will be farmed for hay crop production.

The project as described will (1) provide visible evidence of profitability for various direct geothermal heat applications; (2) obtain resource application, economic, Institutional, and environmental data from field operating conditions that will facilitate decisions concerning utilization of geothermal energy by prospective developers and users; (3) provide a variety of applications from a single heat source; and (4) become an integral part of the college educational program for student training and technical skill applications.

\section{ACTIVITIES DURING PAST YEAR}

1. With the assistance of DOE personnel and Radian Corporation (Austin, Texas), an injection well test was conducted in October of 1981 and an acceptance rate of $60 \mathrm{gpm}$ gravity flow was established; however, higher flow rates were obtained under pressure.

2. Preliminary engineering by the Geo-Heat Center of Oregon Institute of Technology established the feasibility of aquaculture applications. Their engineering calculations indicated that sufficient energy was available to heat a $1 / 2$ acre covered aquaculture pond. 
3. Environmental Aquaculture Services provided consultation for the preliminary design work shown by drawings.

4. The Department of Energy recelved and approved the preliminary design report.

5. Current activities include the issuance of a bid notice for drilling the freshwater well and a request for statement of qualifications from prospective architectural engineering firms to produce the final project blueprints and supervise construction.

\section{PROBLEMS AND LESSONS LEARNED}

1. Infection restriction proved to be a limfting factor for the project. All projects should anticipate such limitations and be prepared to establish alternate applications or solutions.

2. Anticipated costs and time frames for engineering aspects of the project have been greater than anticipated. These time delays have altered the time line for implementation of the construction and reserach aspects of the project.

3. Due to the unique cascade application and concepts involved in the design and engineering of this profect, it has been difficult to find individuals or firms with the specific experience and background to properly plan and coordinate various aspects of the project.

4. An exact economic analysis of this project will prove to be extremely difficult since a true market value can not be established on the educational benefits to be derived by students enrolled in programs relating to each of the project applications. Assumptions used to arrive at any payback period or rate of return must be highly qualified to understand its significance. 
THIS PAGE BLANK 


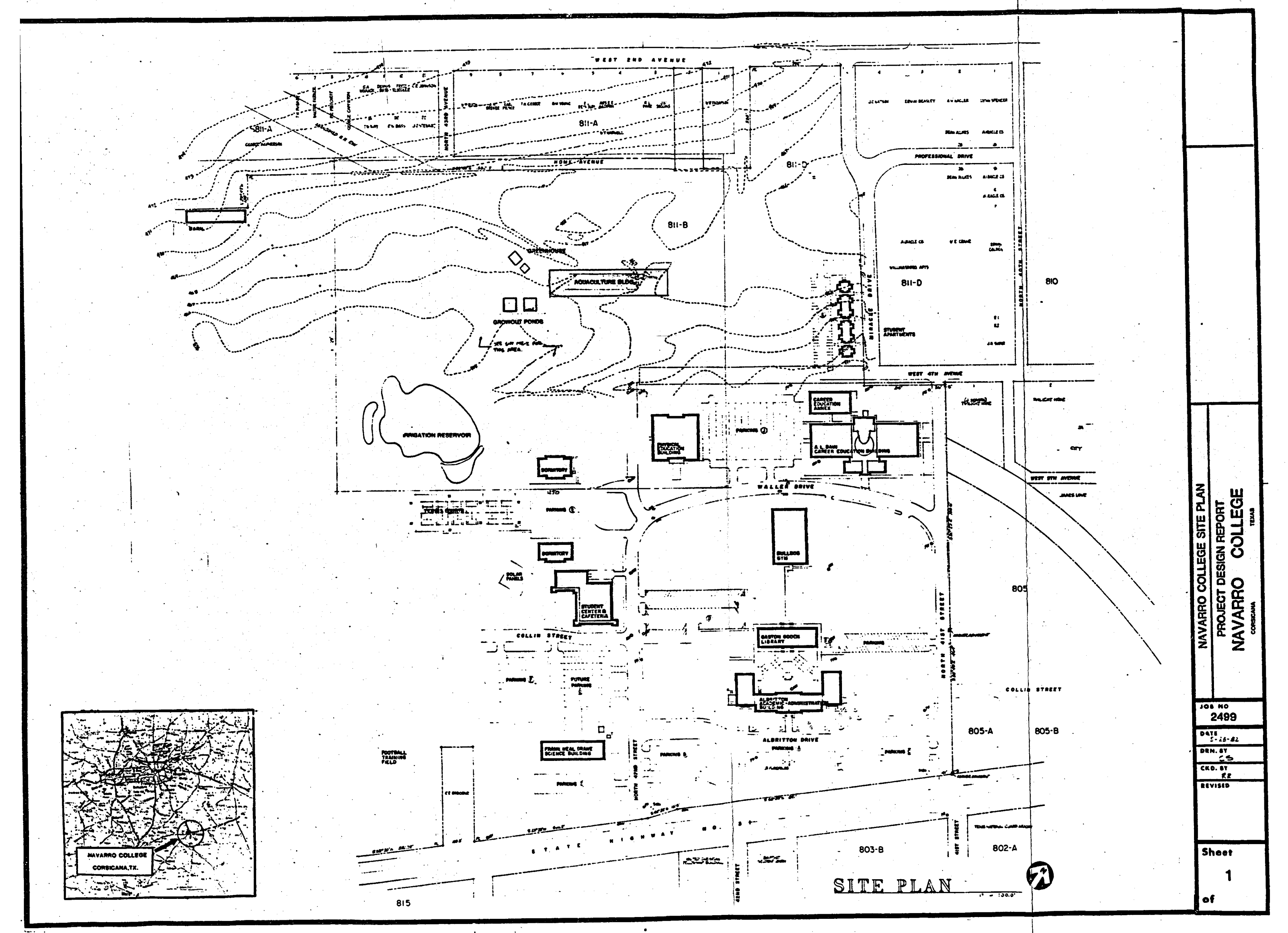




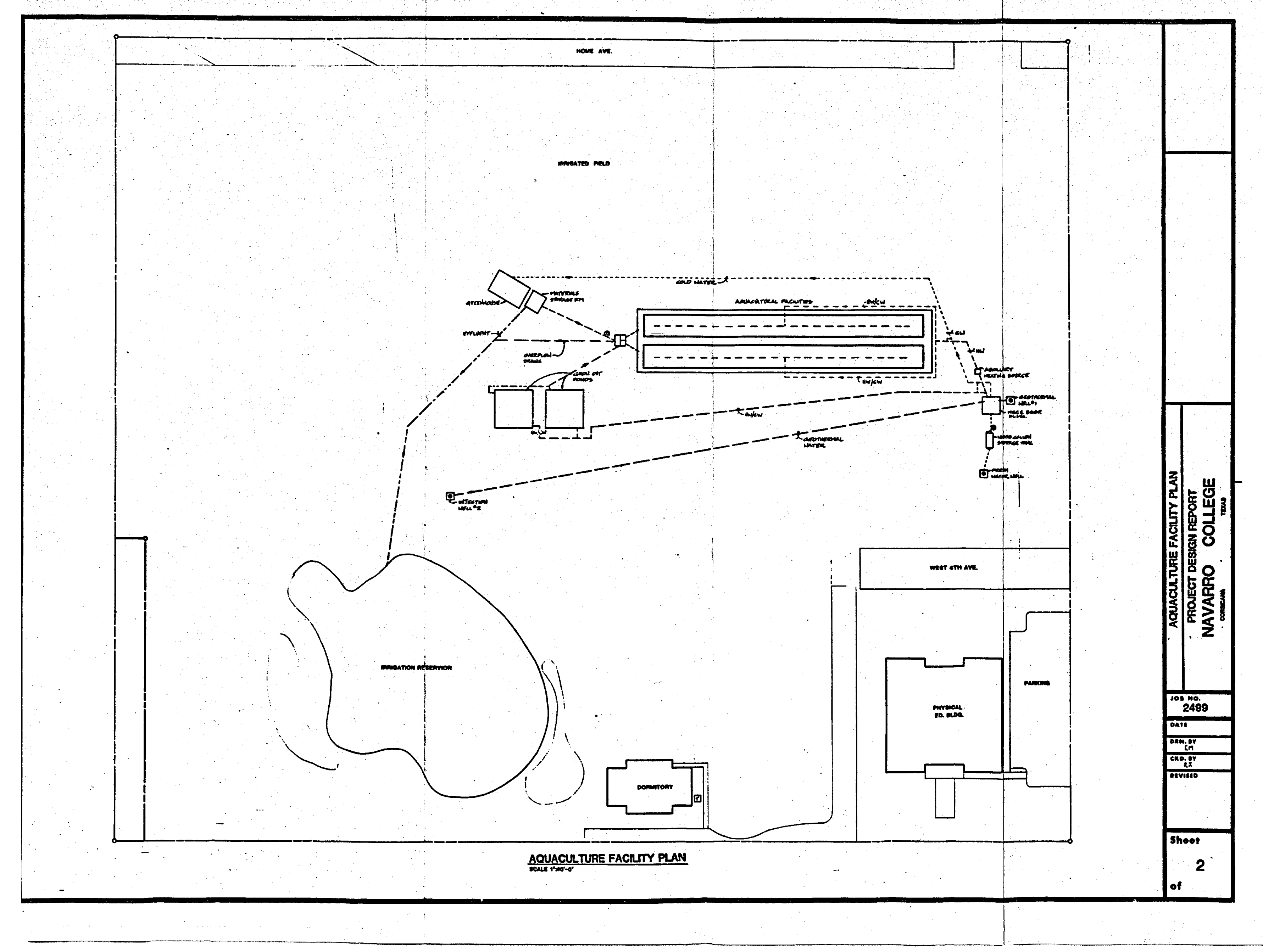




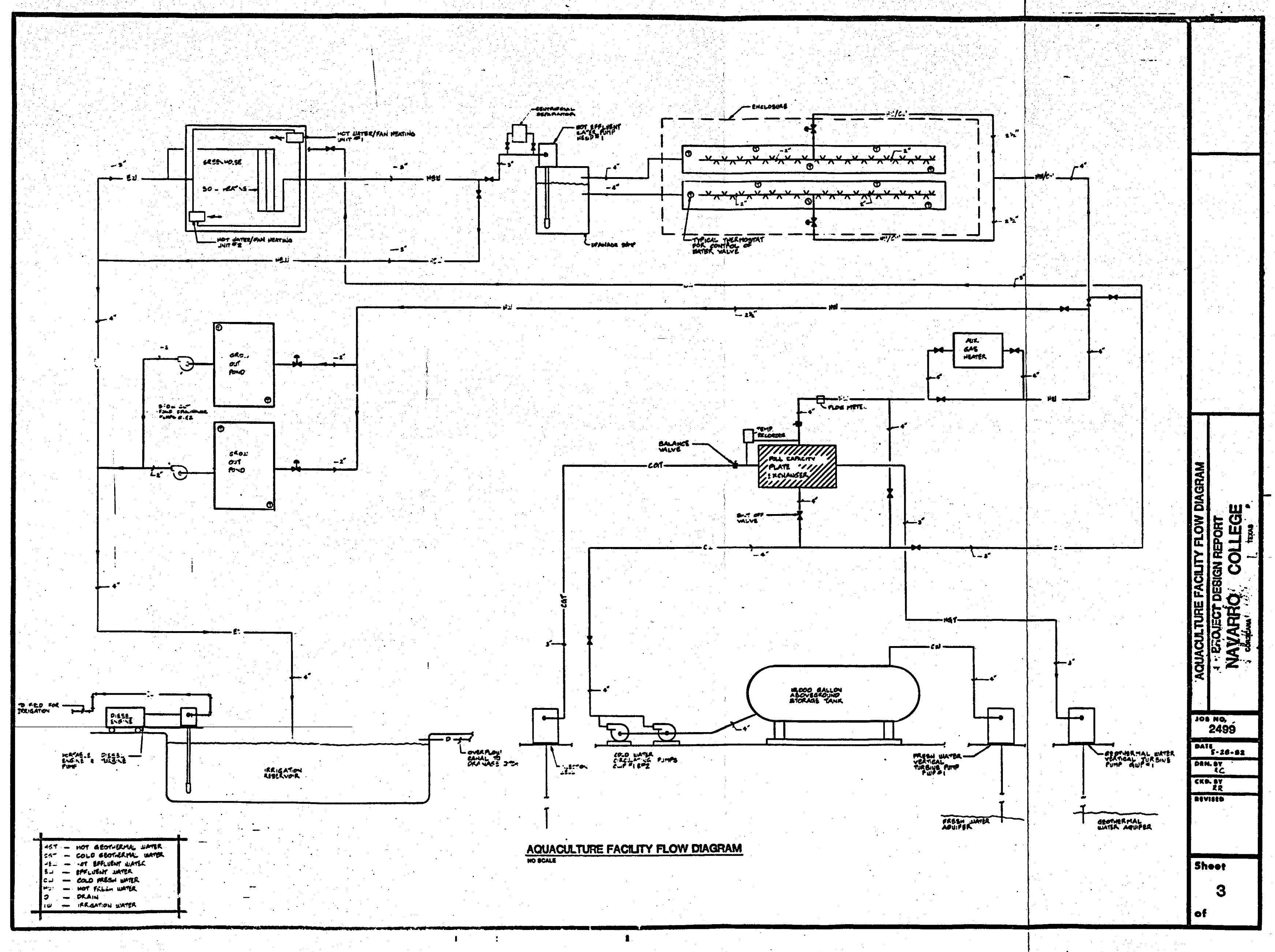




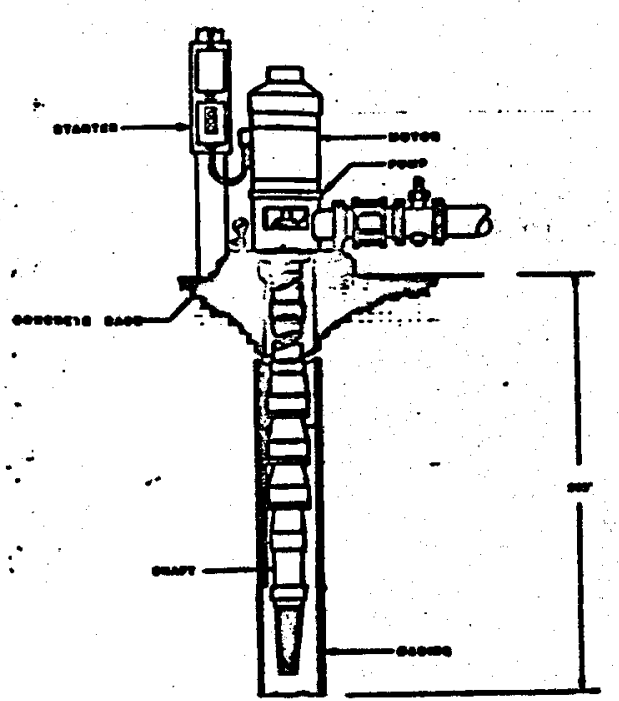

VERTCAL TURBNE WELL PUMP DETAL.
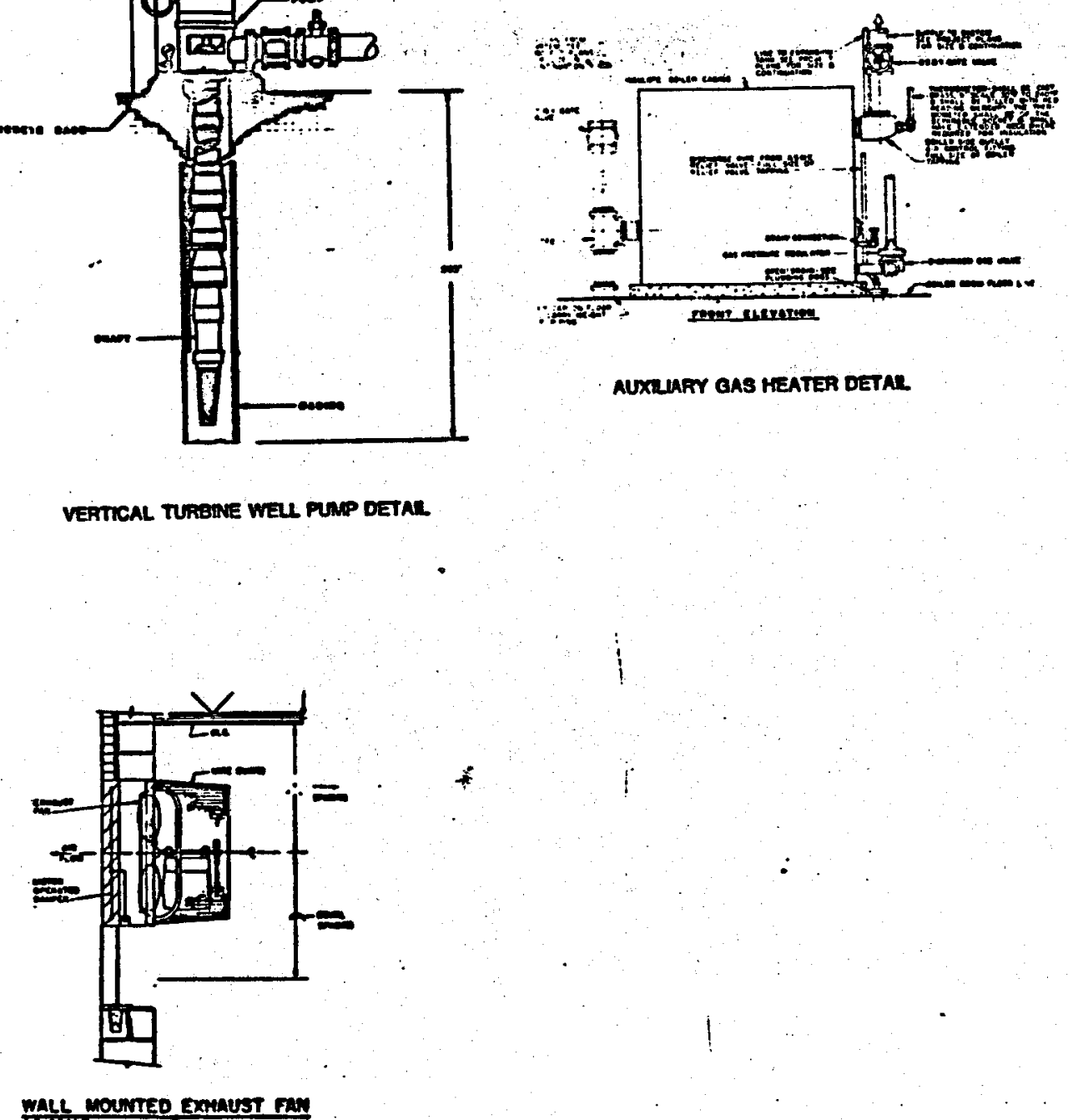

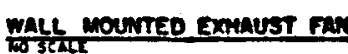

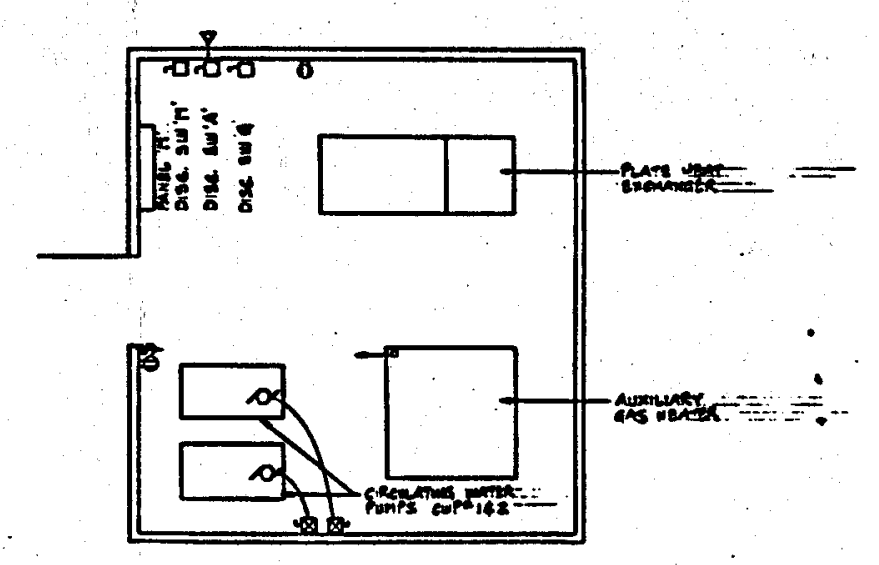

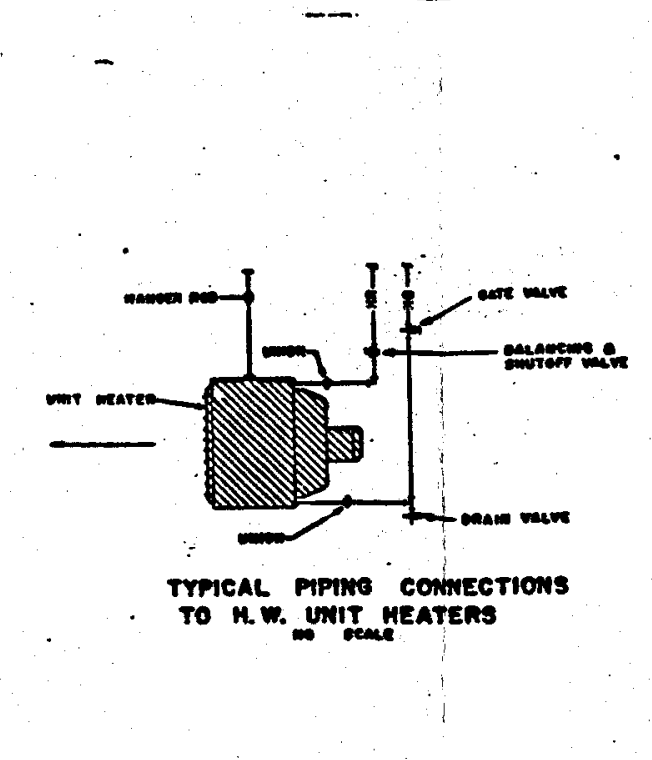

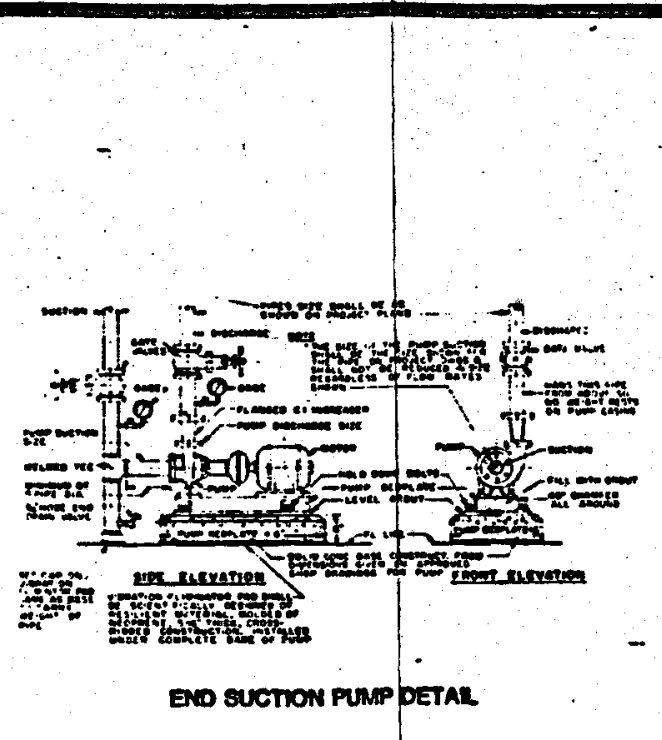

MEGHANCAL EQVP. DLOR

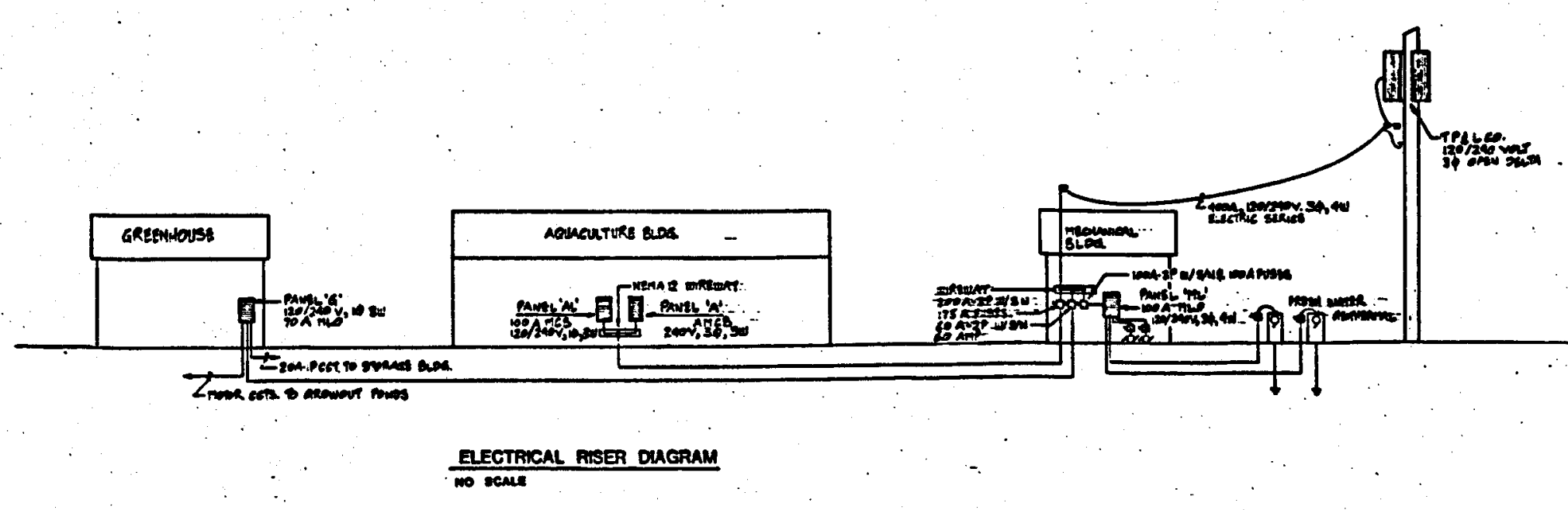


PROJECT TITLE: Floral Greenhouse Industry Geothermal Energy Demonstration Project

RRINCIPAL INVESTIGATOR: RaIph M. Wright, Chairman of the Board

Utah Roses, Inc.

PROJECT TEAM: Utah Roses, Inc.

Energy Services, Inc.

RROJECT OBJECTIVE: To demonstrate to the public the potential offered by geothermal space heating in a highly populated area, by using geothermal heating in a commercial application.

LOCATION DESCRIPTION: Sandy, Utah

13 miles $(21 \mathrm{~km})$ south of Salt Lake City

Population: 51,227, Metropolitan area of 500,000

Area Activities: Agriculture, light industry and commercial development

\section{RESOURCE DATA:}

Well Depth: 5009 ft $(1527 \mathrm{~m})$

Date Complete: $12 / 8 / 79$

Completion Technique: slotted Liner

Wellhead Temperature: $124^{\circ} \mathrm{F}\left(51^{\circ} \mathrm{C}\right)$

Flowrate: $230 \mathrm{gpm}(14 \mathrm{l} / \mathrm{s})$ with pumping

Summary: Several wells in the area of Utah Roses have shows of warm water, including one within 100 yards $(9 \mathrm{~lm})$ of the site, which has $93^{\circ} \mathrm{F}\left(34^{\circ} \mathrm{C}\right)$ water.

The present well was drilled into loosely consolidated sandstone formations beneath the Utah

Roses property, and encountered the primary production of 132 to $140^{\circ} \mathrm{F}$ water at 2800 to 3800 ft. 
CURRENT ESTIMATED

BROJECT COST:

Total:

DOE Share:
$\$ 804,200$

$\$ 455,000$ 578
$\$ 349,200$ 438

TOTAL EXPENDITURES

TO DATE:

$$
\$ 440,000
$$

$\$ 197,000$

\subsection{SYSTEM DESCRIPTIONS}

The original system design was to meet the criteria of being able to heat the entire greenhouse down to outside temperatures of $20^{\circ} \mathrm{F}\left(-7^{\circ} \mathrm{C}\right)$, with the original boiler being retained as supplementary and backup heating, for those days when the temperatures dropped below $200^{\circ}\left(-7^{\circ} \mathrm{C}\right)$. This design is with reference to an inside temperature of $60^{\circ} \mathrm{F}\left(16^{\circ} \mathrm{C}\right)$ at night, and $72^{\circ} \mathrm{F}\left(22^{\circ} \mathrm{C}\right)$ during the day.

However, the production well was considerably lower in temperature than was anticipated, and the production capability of the formation was substantially lower than hoped. Therefore, the modified design paramenters were such that geothermal heating can only replace $2 / 3$ of the annual heat needs of the facility, and can operate alone (without assist from the boilers) only down to outside temperatures of $40^{\circ} \mathrm{F}$. 


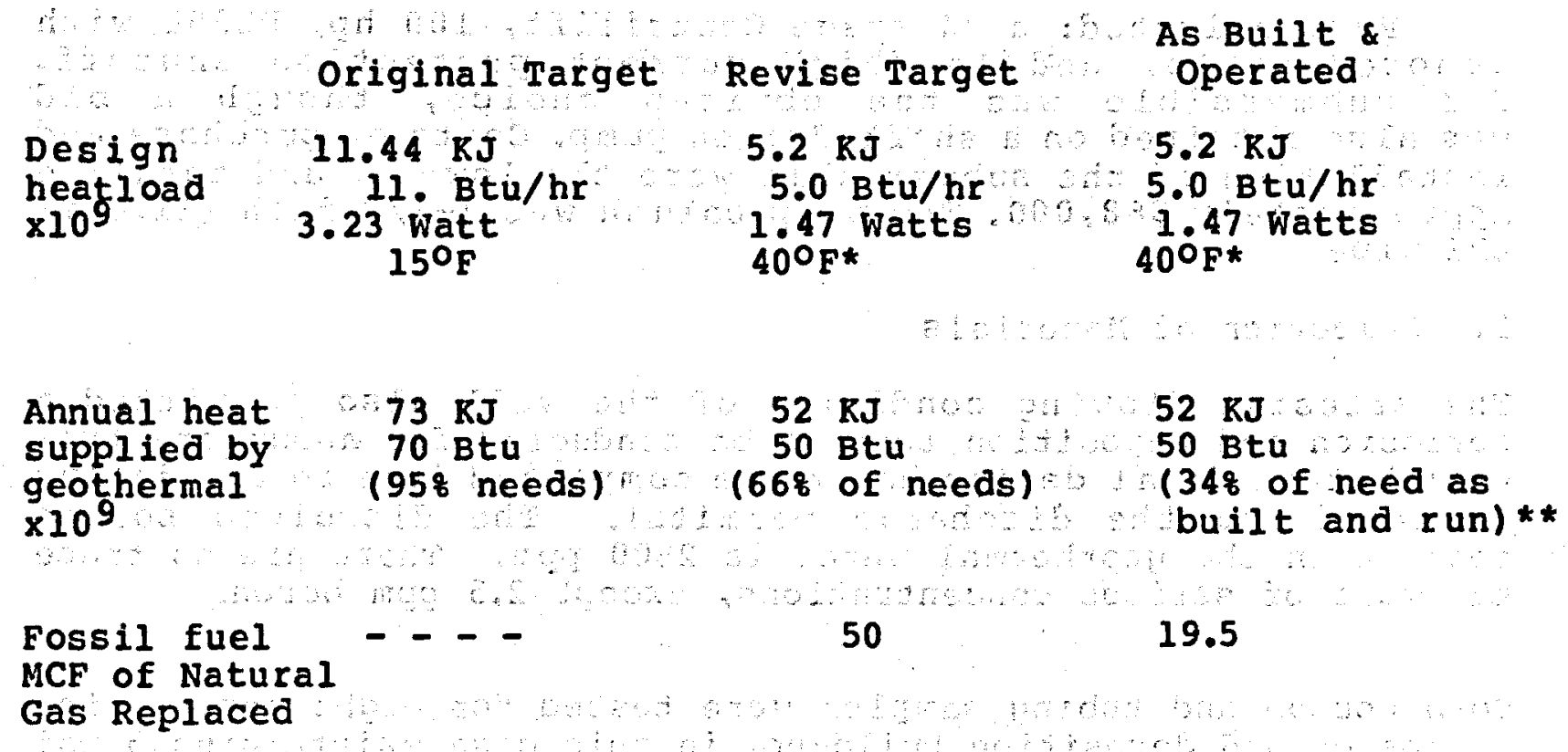

\section{The fuel bill during the winter of 1980-81 was $\$ 150,000$}

* Some adaitional double covering was aded to the roof between the two designs.

** The electrical consumption was $333,090 \mathrm{KWH}$

The area being heated is 250,000 sq. ft (6 acres or 2.4 hectares, $24,000 \mathrm{sq}$. meters). Approximately 448 of the roof is double polyethylene sheet (air inflation), the remainder is single fibreglas. Approximately 208 of the side walls 8 ft $(2.5 \mathrm{~m}) \mathrm{high}$ are double polyethylene sheet with air inflation. Average Ufactor is about $1.2 \mathrm{Btu} / \mathrm{hr}-\mathrm{deg} . \mathrm{F}-\mathrm{sq} . \mathrm{ft} .\left(6.8 \mathrm{w} / \mathrm{m}^{20} \mathrm{~K}\right)$. The degree days of heating required for greenhouse operation, based on average-year conditions, is approximately 4300 deg F-days.

The above information resulted in a design for heat loads for the greenhouse.A series of economic-engineering calculations were conducted to determine the optimum depth for setting the pump, and what size of pump to use. It was desired to maintain a minimum of 25 psi (172kpa) pressure on the geothermal fluid throughout its entire traverse through the well and the geothermal system in the greenhouse, for the purpose of minimizing corrosion and desposition from the sulfide, bicarbonate, calcium and chloride ions in the geothermal water.

The apparent optimum conditions arrived at were as follows:

Pump setting depth $=1200 \mathrm{ft}(364 \mathrm{~m})$

Long-term flow rate for a nominal $1000 \mathrm{ft}(303 \mathrm{~m})$ drawdown $=190 \mathrm{gpm}\left(0.012 \mathrm{~m}^{3} / \mathrm{s}\right)$ 
Pump selected: a 44 stage Centrilift, $100 \mathrm{hp}$, D225B with armored cable, and low/high current protection shutoff. The submersible was the obvious choice, though a bid was also obtained on a shaft-driven pump. Costs of purchase and installation of the submersible were the lowest, and totalled approximately $\$ 68,000$. The pump column was $4-1 / 2$ inch $(11.4 \mathrm{~cm})$ API pipe.

\section{Selection of Materials}

The artesian flowing condition of the well also permitted a corrosion and deposition test to be conducted for about one full year before final design had to be completed (due to the delays in receiving the discharge permits). The dissolved solids content in the geothermal water is $2800 \mathrm{ppm}$. There are no trace minerals of serious concentrations, except $2.5 \mathrm{ppm}$ boron.

Both coupon and tubing samples were tested for eight months for corrosion and deposition build-up, in this case maintaining 5 psi back-pressure on all materials during most of the test period, except when the apparatus was opened to change or examine the samples. Materials tested were carbon steel, stainless steel, copper, and the stainless-clad copper used in some plumbing fixtures. Coupon sample tests also included various types of brasses. The carbon steel sample lost 1-1/28 of its weight, but all other coupon samples gained weight. For the tubing samples, the copper tubing showed significant film corrosion, to black scaly cuprous or cupric sulfide. The hydrogen sulfide content in the water was less than $.25 \mathrm{ppm}$, but still the corrosion testing showed significant attack to the copper. It is possible that some oxygen entered the system during the testing phase, during those periods when samples were being inserted and removed, but the copper film corrosion (though not more than 5 mils over the entire 8 month test) was still more than one would expect from the brief periods that the testing apparatus was open to the atmosphere. Therefore, it is believed that the hydrogen sulfide content was detrimental, both because of its presence alone and because of a small amount of dissolved oxygen present in the water or the test apparatus.

For piping to the heat exchangers, PVC pipe was selected, because it retains an adequate amount $(308)$ of its design pressure rating at these low temperatures $\left(122^{\circ} \mathrm{F}\right.$ or $\left.50^{\circ} \mathrm{C}\right)$, and showed no build-up of scale during the testing period. The use of PVC pipe made it the least expensive distribution system possible.

Despite the results of the testing of the copper pipe, it was nevertheless decided to use water-to-air heat exchangers of offthe-shelf type, constructed with copper tubing. The use of stainless steel heat exchangers would have increased the price of the heat exchangers by nearly 10 times. various brasses for the tubing would have quadrupled the price of the units. The 
new units were purchased for $\$ 35,000$. However, it was decided to place $25 \mathrm{ft}(7.6 \mathrm{~m})$ of 1 -inch $(2.5 \mathrm{~cm})$ diameter copper tubing ahead of each heat exchanger to act as a "getter" for the copper piping in the heat exchanger. The $4-1 / 2 \mathrm{gpm}\left(0.3 \times 10^{-3} \mathrm{~m} / \mathrm{s}\right)$ flow per unit hopefully will protect the copper in the heat exchangers from corrosion, by allowing the lead-in copper tubing to accept the reaction with the $\mathrm{H}_{2} \mathrm{~S}$ in the system, and thereby (hopefully) removing the $\mathrm{H}_{2} \mathrm{~S}$ so there would be no attack on the heat exchanger tubing. The $25 \mathrm{ft}(7.6 \mathrm{~m})$ of tubing provides 10seconds of residence time of the water before it reaches the heat exchanger. It is now planned to also place a calibration getter specimen unit in the main supply line, and to periodically examine the specimen. There is obviously much concern over the long range durability of the heat exchanger coils in the presence of the geothermal water, with its small concentration of hydrogen sulfide. Tubing wall thickness is nominally $30 \mathrm{mils}$. The choice of using these units directly, instead of a secondary system of treated water with heat transfer to it via plate heat exchangers was primarily economic. The few degrees of lower source temperature to the heat exchangers would significantly reduce the yearly heat extracted. For instance, a $5^{\circ} \mathrm{F}\left(3^{\circ} \mathrm{C}\right)$ drop will cost about $\$ 16,000$ per year in added fuel costs. Therefore, it was decided to accept the risk of corrosion to try and reduce that risk by keeping adequate pressue on the system and to drain and refili the system with corrosion inhibitor when not in use during four summer months.

The piping system in the greenhouse was constructed in the following manner. A backpressure relief valve is set at 25 psig (172 Kpa), and there is a check valve in the pump outlet. Fiftytwo heat exchangers were used, 14 of which were al ready in the greenhouse and had been used for years as steam-to-air heat exchangers on $5 \mathrm{psig}(34.5 \mathrm{Kpa})$ steam. These were left in place and converted to hot water units. All of the units were typical forced air ( $3 / 4$ H.P. (560W) fan). finned tube (3/4n (1.9cm) tubes), 2 to 4 rows, face area of 7 to 9 sq. ft. $\left(1 \mathrm{~m}^{2}\right)$ with ratings in the neighborhood of 300,000 to 400,000 Btu/hr $(312,000$ to $416,000 \mathrm{kj})$ on $5 \mathrm{psig}$ steam. The ratings on $1200^{\circ} 49^{\circ} \mathrm{C}$ ) water inlet temperature were nominally $25 \%$ of this steam rating.

\subsection{LESSONS LEARNED \& QPERATING EXPERIENCE}

Since this greenhouse has only been operating on its geothermal heating system for 6 months (as of this writing), extensive operating experience has not been obtained. Performance of the heat exchanger system is, however, within about 108 of the design conditions. The system extracts $23^{\circ} \mathrm{F}\left(13^{\circ} \mathrm{C}\right)$ of heat from the geothermal fluid with the inside temperature held at $70^{\circ} \mathrm{F},\left(21^{\circ} \mathrm{C}\right)$ and $32^{\circ} \mathrm{F}\left(0^{\circ} \mathrm{C}\right)$ from the water with the inside temperature at 
$600 \mathrm{~F}(160 \mathrm{C})$ during the nightime hours. There are no heat exchangers operating with fresh cool outside air in this building, which, if it were the case, would allow the geothermal water to be cooled to lower temperatures than the $900 \mathrm{~F}$ (320 C) minimum discharge temperatures observed to date (inlet temperature to the greenhouse has been virtually constant at $\left.122^{\circ} \mathrm{F}\left(50^{\circ} \mathrm{C}\right]\right)$.

Geothermal fluid flow rates from the well and pump system have been within about 88 of the predictions, based on flow meter readings which are probably no more accurate than 58 . After a steady three weeks of operation, 24 hours per day, flow from the well-pump system is indicated to be $165 \mathrm{gpm}$. $\left(0.01 \mathrm{~m}^{3} / \mathrm{s}\right)$. Design conditions for this pump were that $180 \mathrm{gpm}\left(0.011 \mathrm{~m}^{3} / \mathrm{s}\right)$ should result after 10 days of steady drawdown (flow).

It had originally been proposed that during daylight hours, especially on sunny or partly cloudy days, that the pump be shut off too allow the well to recover. Only for the few winter periods with extensive cloudy weather should the pump be kept running continuously. However, the grower prefers the humidity control which is possible during the daylight hours by keeping the geothermal system operating at full capacity and providing outside ventillation.

The operational mode is to start and stop the geothermal pump manually, no more than once a day. On moderate days, when the sun requires the greenhouse to be ventilated under normal conditions, the pump is started near dusk and turned off about two hours after sunrise. However, on dull days during the winter season, the pump is run 24 hours a day, providing humidity control during the daylight hours by permitting ventilation.

In the six months of operation to date, the only significant operational difficulties have been caused by failure of the only flow meter used to monitor output of the well.

There are certain environmental controls that must be recorded in the daily operational log, as follows:

Total number of hours that the system was operated, from which the gallons of water flowed can be determined.

Weekly monitoring. of the conductivity of the discharged water.

Quarterly sampling and reporting to the EPA of the principal constituents in the discharged water (both radioactive and chemical contaminants are reported). 
The electricity cost to operate the pump and fans was calculated, under original design conditions of only nightime operation, to be $\$ 18,000$ per year. Operation during the daylight hours on the dull days will increase the annual electric bill for the pump by about $\$ 4,000$. The increased yield in rose production far exceeds the cost of this additional pump operation. (Note, normal gross for the greenhouse is in the range of $\$ 1,000,000$, and the reduced humidity and reduced incidence of mildew from the extra use of geothermal heat more than compensates for the extra electricity cost.) The total electrical cost for the operating season of 1110-81 to $6-12-82$ was $\$ 12,992.99$. The total kwH used during this period was 333090 .

The deep setting location for the pump caused significant design problems to avoid overpressuring the PVC piping system inside the greenhouse. When the pump is first started, with water to the surface of the well, well head pressure could rise to approximately 550 psig, (3792 Kpa) gradually reducing until the well was drawn down to the $900(273 \mathrm{~m})$ to $1000 \mathrm{ft}(303 \mathrm{~m})$ level, at which time the well head output pump pressure would be about 100 psig $(689 \mathrm{Kpa})$ with output flow of about $200 \mathrm{gpm}\left(0.0123 \mathrm{~m}^{3} / \mathrm{s}\right)$. Several valves were designed into the system to reduce both the peak "steady-state" pressure and the surge and water hammer pressures. A pressure control valve set at nominally 25 psig (172kpa) was installed at the discharge end of the system. At the well head, a surge control valve and a by-pass pressure relief valve were installed to reduce the surges and to recycle any bypassed geothermal fluids back into the well. The well head piping before these valves is rated at 600 psig (4137 Kpa).

The project had been delayed for one full heating season by delays in obtaining state and federal discharge permits. The bulk of this delay came as a result of a misunderstanding of the proceedure followed by EPA in issuing the NPDES permit. The permit was applied for before the project began, and went through the normal 180-day period of public notice, public comment, and other administrative functions. During the 180-day period, EPA, through discussions with project personnel, was encouraged to at least issue temporary authority for discharging during well drilling and testing. This permission was given, just in time for each procedure to be conducted.

Upon completion of the well, the Utah State Dept. of Health was asked to give permission for the discharge, and the project manager was told that once Utah State had aproved, the EPA would issue a permanent discharge permit (for a 5-year period, which is their maximum.) However, when the state approval was obtained in October, and EPA was asked to issue the NPDES permit, the project manager was informed that a new application would have to be processed by EPA. The EPA would attempt to expedite the process in 90 days, but this effort failed.

The geothermal system at the facility appears to be running smooth according to design expectations. There is, however, a 
major concern over the long term effect of corrosion on the copper tubes.

Despite the very low competitive prices of natural gas, and the conversion cost at Utah Roses a simple payback of about seven years was calculated. When gas decontrol occurs and gas prices in Utah double, these payback periods would be cut in half. These figures take no credit for tax incentives, nor do they consider the penalty of the current high interest rate which have taken the edge off of some of the jubilation over the simple economic success formula of the Utah Roses project. 


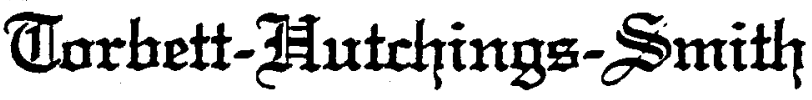 Aftemorial THoppital
}

\author{
322 Coleman Strext
}

Telephone: 817-883-3561

Allurlin, Texas ZEEБ1

July 1982

PROJECT IITLE:

Direct Utilization of Geothermal Energy at TorbettHutchings-Smith (THS) Memorial Hospital, Marlin, Texas

PRINCIPAL INVESTIGATOR: J. D. Norris, Jr., Administrator, THS Memorial Hospital PROJECT TEAM:

Prime Contractor:

Geothermal Consulting

Engineers:

Architects:

HVAC Consulting

Engineers:

Drilling and

Completion:

Constructors :

Surface Disposal:

Community

Coordination:

Legal:

Accounting :
THS Memorial Hospital, Marlin, TX

Radian Corporation, Austin, TX

Spencer Associates, Austin, TX

Ham-Mer Consulting Engineers, Austin, TX

Layne Texas Company, Dallas, IX

Lochridge-Priest, Inc., Waco, TX

City of Marlin

Marlin Chamber of Commerce

J. Welch, Marlin, TX

W. M. Parish \& Co., Marlin, TX

PROJECT DESCRIPTION:

The purpose of this geothermal project is to retrofit the 130 -bed hospital space and water heating systems to use geothermal energy, thereby reducing its dependence on fossil fuels. The geothermal heating system will supply heat to the hospital domestic water system, as well as to the space heating and outside air preheating systems. At present, heat input to these systems is accomplished via steam provided by a low-pressure, natural-gas-fired boiler: This boiler system will remain in place as backup and augmentation. Readily available commercial piping, pumps, valves, controls, plate heat exchangers, and insulation will be utilized.

The final phase is a one-year operational demonstration phase, during which potential geothermal users will be encouraged to visit and observe the geothermal heating system. 
THS MEMORIAL HOSPITAL

Marlin, Texas

\section{LOCATION DESCRIPTION:}

THS Memorial Hospital is located in Marlin, Texas (population 6,350 ), approximately 30 miles southeast of Waco, Texas (Figures 1 and 2).

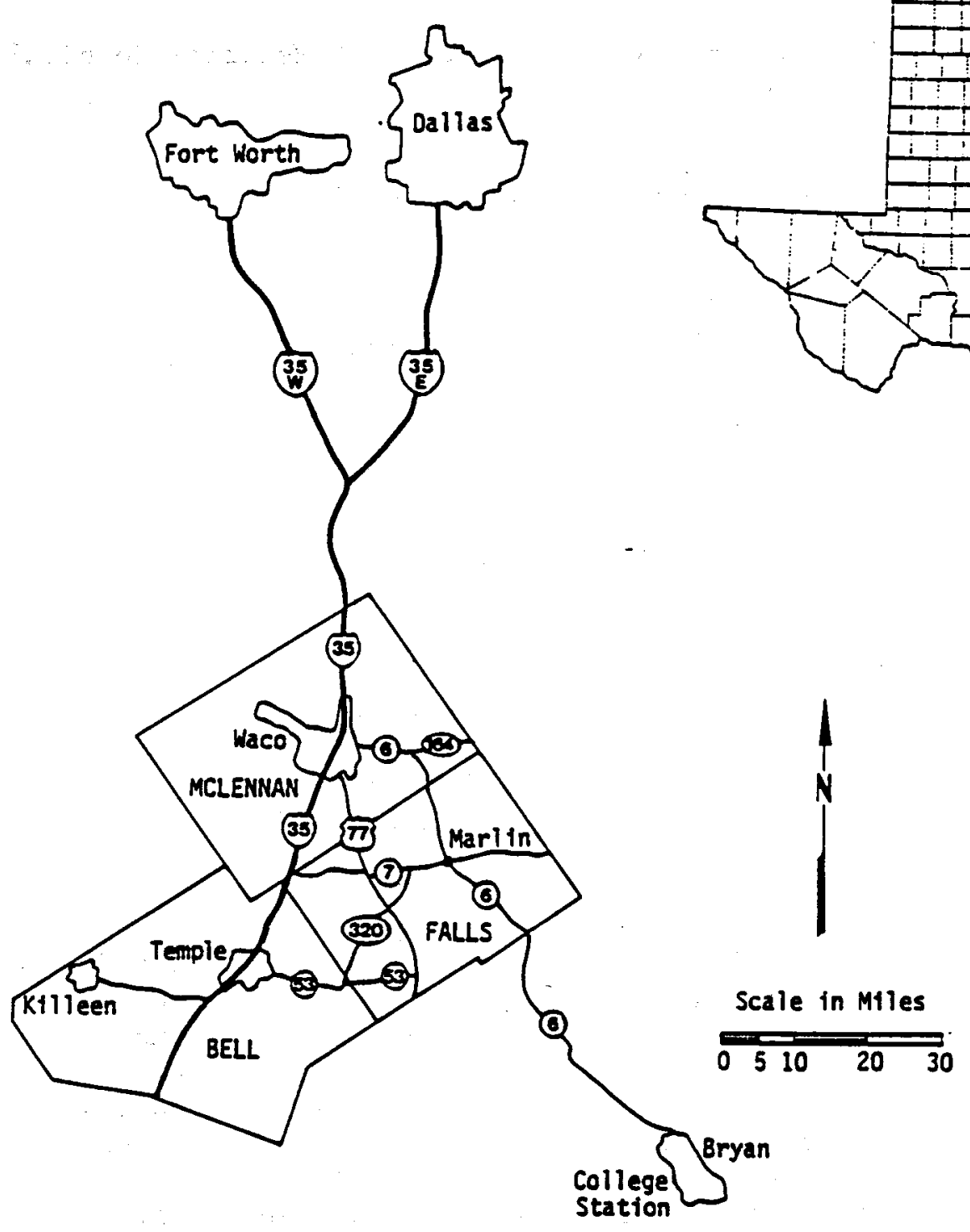

Figure 1. Geographical Setting of Marlin, Texas 


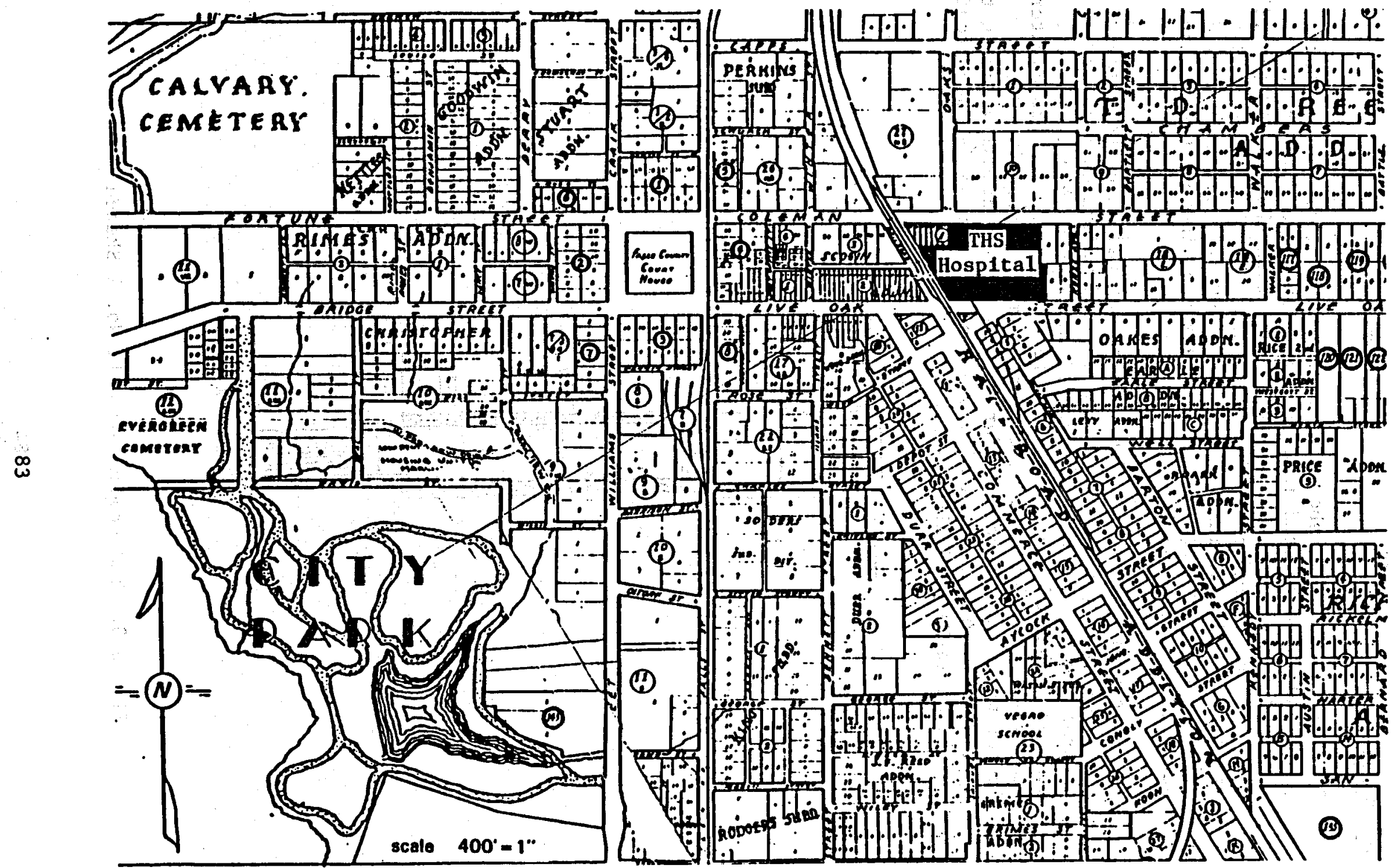

Figure 2. THS Memorial Hospital Location in Marlin 


\section{RESOURCE DATA:}

The production well, shown in Figure 3 , is 3,885 feet in total depth and was completed in July 1979. The production zone is screened (5-1/2" 0.D. mill slot screen) from about 3,613 to 3,883 feet. Pump testing of the well has produced flow rates of $315 \mathrm{gpm}$ of $153^{\circ} \mathrm{F}$ fluid containing less than $4,000 \mathrm{mg} / 1$ total dissolved solids (TDS). Hydrogen sulfide levels are minute. Gross alpha activity is less than 2 pCi/1.

The source of the heat is faulting associated with the Ouachita fold belt, which outcrops in Arkansas and underlies much of central Texas. The coarser-grained sandstones (especially the Hosston member of the Travis Peak formation) are the groundwater reservoirs that define the aquifer shown in Figure 4. The factor which is responsible for the area's geothermal value is the hydraulic interconnection of deeper and shallow sandstones provided by the Mexia-Talco fault system.

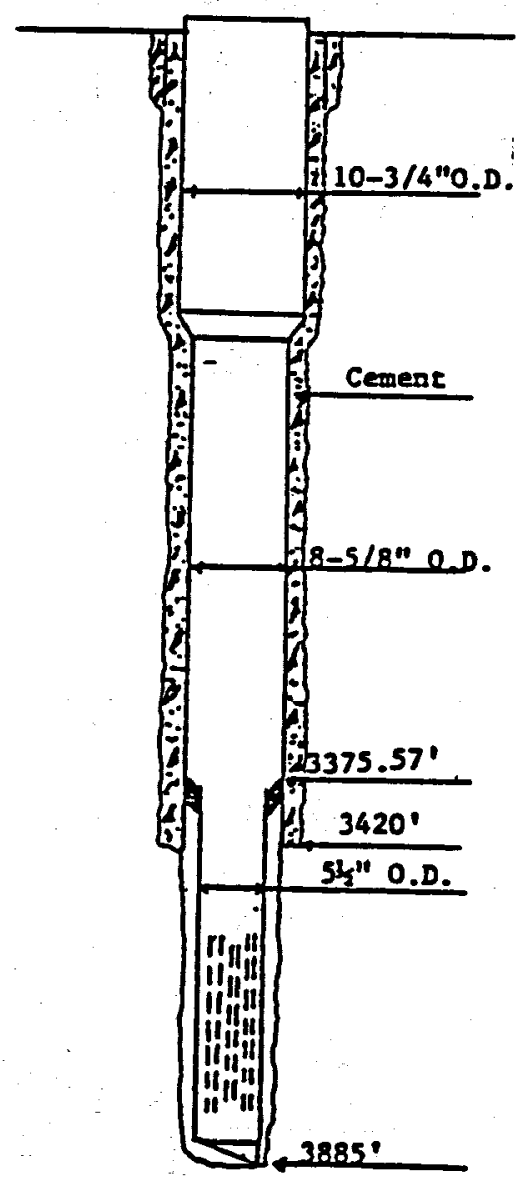

Figure 3. THS Production Well No. 1 Sketch 


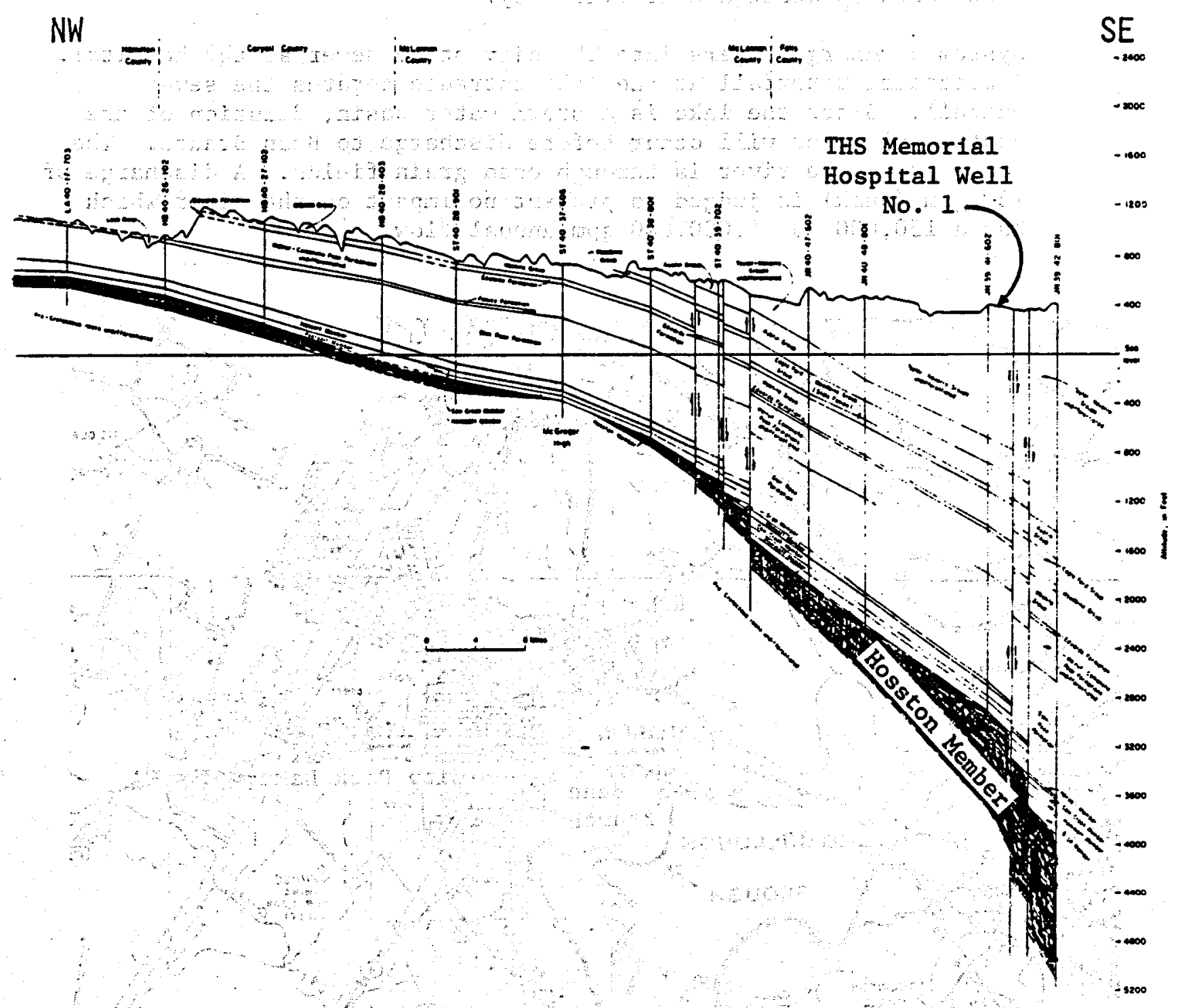

Figure 4. Geologic Dip Section Showing Hosston Member Passing Through Marlin, Texas

\section{SURFACE DISPOSAL:}

An environmental assessment of the disposal route showed that surface disposal of the 4,000 mg/I TDS THS Memorial Hospital geothermal water wquld not present an unacceptable environmental 1mpact. Both the Texas Rallroad Commission (which regulates saline water disposal) and the EPA issued disposal permits.

Figure 5 presents an overview of the disposal route from the 5-acre City Park Lake on to the Brazos River via Bean Branch and McCullough Slough--a distance of about five miles. Figure 2 shows 
a more detailed view of the hospital's relationship to City Park Lake which is about a half mile away.

System discharge enters into the city storm sewer at the hospital. A cascading waterfall at the lake entrance aerates the sewer outfall. Since the lake is a storm water basin, dilution of the geothermal water will occur before discharge to Bean Branch. The traverse to the river is through open grain fields. A discharge of 160 gpm (peak) is judged to present no impact on the river which has a 150,000 to $24,000,000 \mathrm{gpm}$ annual flow.

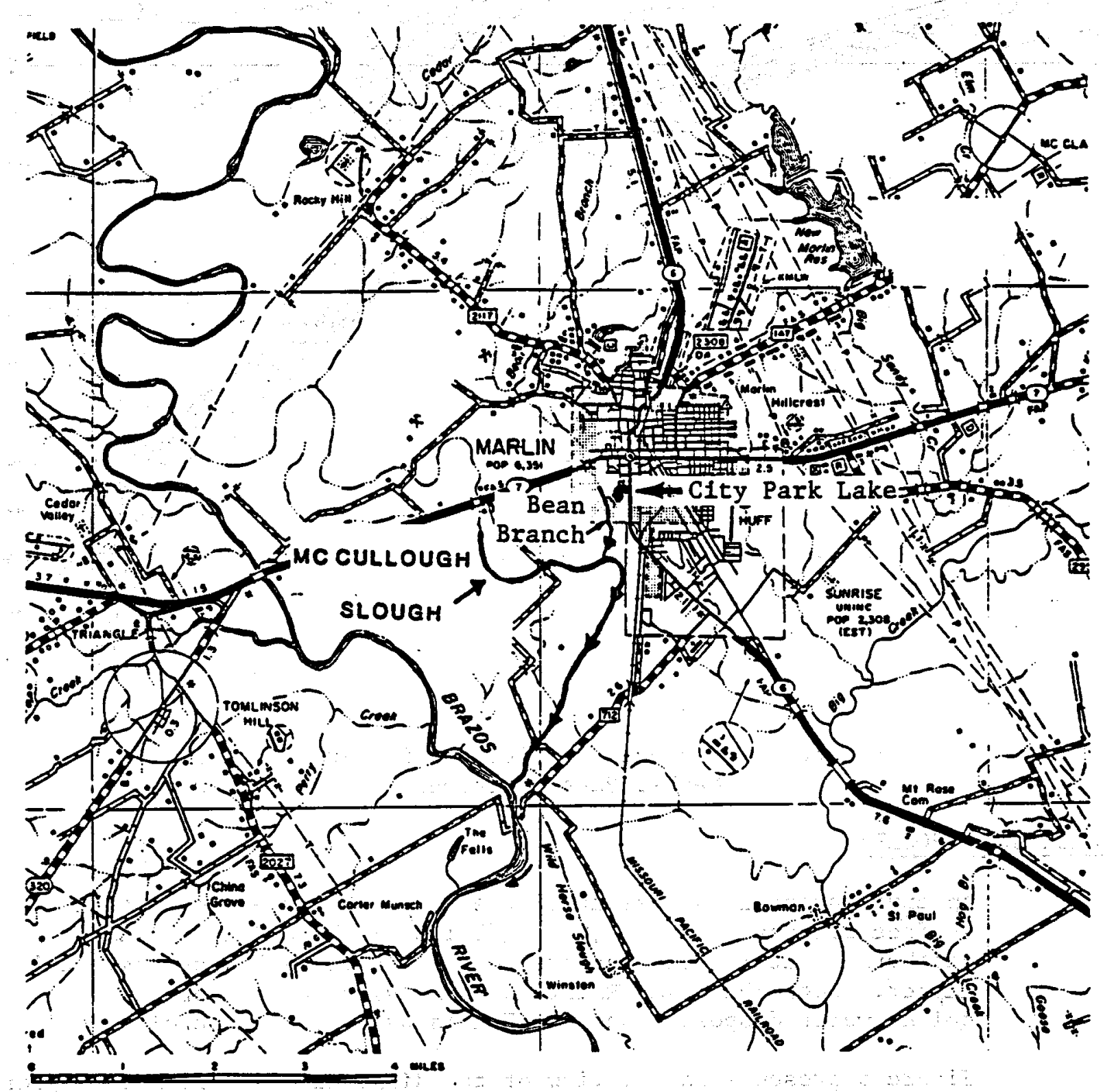

Figure 5. Surface Disposal Route from City Park Lake to the Brazos River 
THS MEMORIAL HOSPITAL

Marlin, Texas

ESSENTIAL PERMITS AND EXEMPTIONS:

- DOE/EA: EIS Negative Declaration

- Texas Railroad Commission: Approval

for Off-Lease Surface Discharge of Geothermal Discharge Water

- Environment Protection Agency: National Pollution Discharge Elimination System (NPDES) Permit No. TX0086321

- Texas Air Control Board: Permit Exemption

- Texas Department of Health: Reviewed
August 8,1980

March 17, 1980

June 14,1981

August 3, 1981

May, 15, 1981

\section{SYSTEM FEATURES:}

Figure 6 shows the geothermal fluid production system. A submerged pump that requires less than $10 \mathrm{HP}$ at the design maximum flow rate of $160 \mathrm{gpm}$ is set at $200 \mathrm{feet}$ and used to supply $155^{\circ} \mathrm{F}$ geothermal fluid to the plate heat exchangers ( $\mathrm{PHX}$ ). To conserve the geothermal resource and electric pumping energy costs, the pump runs at a speed directly proportional to the system heating load. An electronic varlable speed drive (VSD) unit controls the pump speed (and thus flow rate) according to the system discharge temperature set point of about $100^{\circ} \mathrm{F}$. The VSD unit is mounted in the geothermal equipment room with the PHX's. As the system load increases, the discharge temperature will drop and a signal sent to the VSD will cause the VSD to speed up the pump. The higher flow rate w111 supply more heat to the PHX's and the discharge temperature will thus rise closing the loop. Geothermal fluid rates, quantities and heating rates are monitored by a small computer.

Four PHX's are located in the geothermal equipment room. One PHX supplies heat to the domestic water heating system. A conductance measuring system monitors the output of the heated potable water to insure that if geothermal water has leaked, within the PHX, from the primary to the secondary side, an operator alarm is activated and such water heating is automatically terminated. Two PHX's supply heat to the building heating system, and the fourth PHX supplies heat to the outside-air-preheating system. Other 


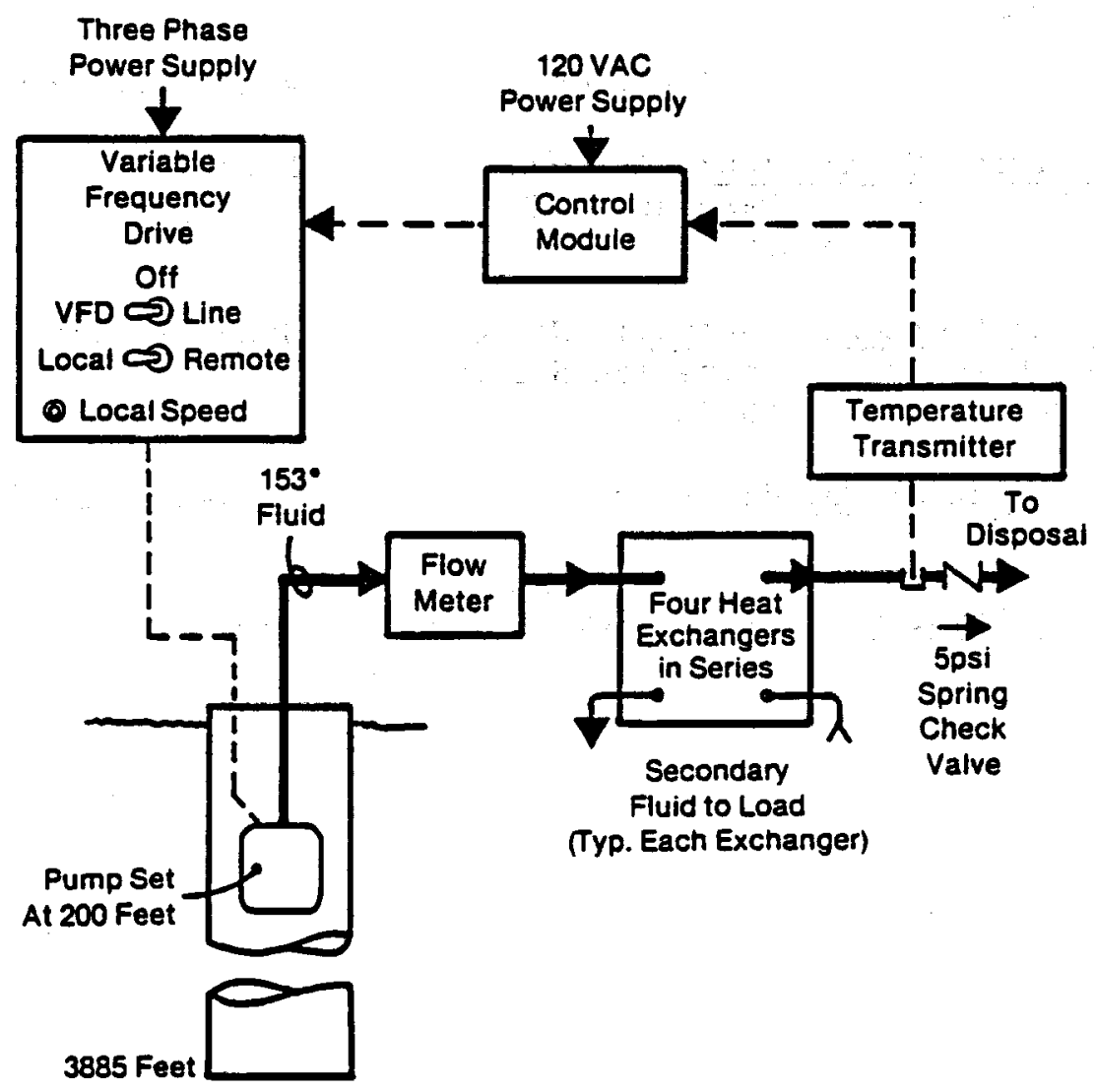

Figure 6. THS Hospital Geothermal Fluid Production System

auxillary functions such as laundry driers, office heaters and surgery room air handling also receive geothermal heat. The existing low-pressure steam boilers remain in place and automatically activate to augment the geothermal heating system. Or, the boilers still heat the hospital when it is necessary to shut down the geothermal system for $0 \& M$ activities.

Scale control is achieved by maintaining a closed geothermal fluid loop, which is maintained at 5 psig, minimum, until discharge. A backwash feature for the PHX primary side, coupled with the ease of PHX disassembly and plate cleaning (defouling), assures that potential scaling is efficiently dealth with. Corrosion control is achieved by: 1) precluding oxygen intrusion via a closed geothermal loop; 2) selecting Type 316SS PHX plates which are known to resist corrosion in the Marlin fluid; and 3) utilizing CPVC piping for all the geothermal pipes. 
The THS Hospital's geothermal system construction phase was completed in January 1982 with concurrent beginning of the one-year warranty period. Initial start-up and shake-down procedures began in December 1981. A system acceptance test was conducted which resulted in customer sign-off and acceptance of the installed system.

The initial operational gas savings for the THS Hospital has been both dramatic and satisfying as is depicted in Figure 7. During these first seven months of operation, the THS Hospital's natural gas consumption has been reduced by 75 percent. The main boiler has been shut down completely and no standby steam is used for domestic water heating. The geothermal system was put to a stringent test when--during shakedown--the hospital's natural gas was interrupted one night and the geothermal system maintained the hospital space heating with an outside temperature of $5^{\circ} \mathrm{F}$. Natural gas consumption that remains is accountable for cooking, laundry drying and high temperature $\left(180^{\circ} \mathrm{F}\right)$ water boosting for kitchen and laundry uses.

0
0

O
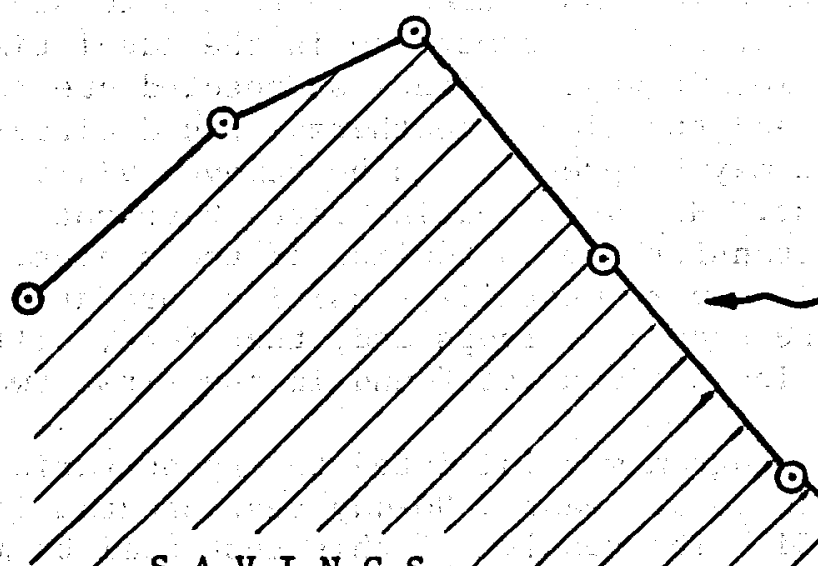

S A V I N G S

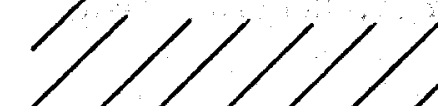

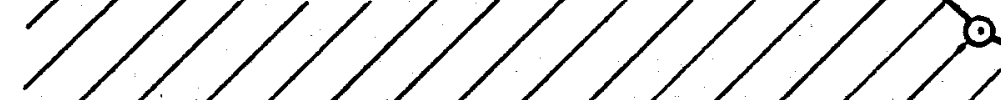

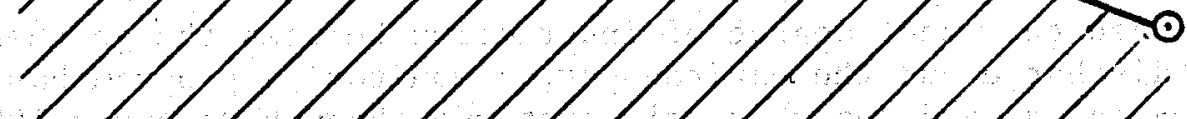

Q

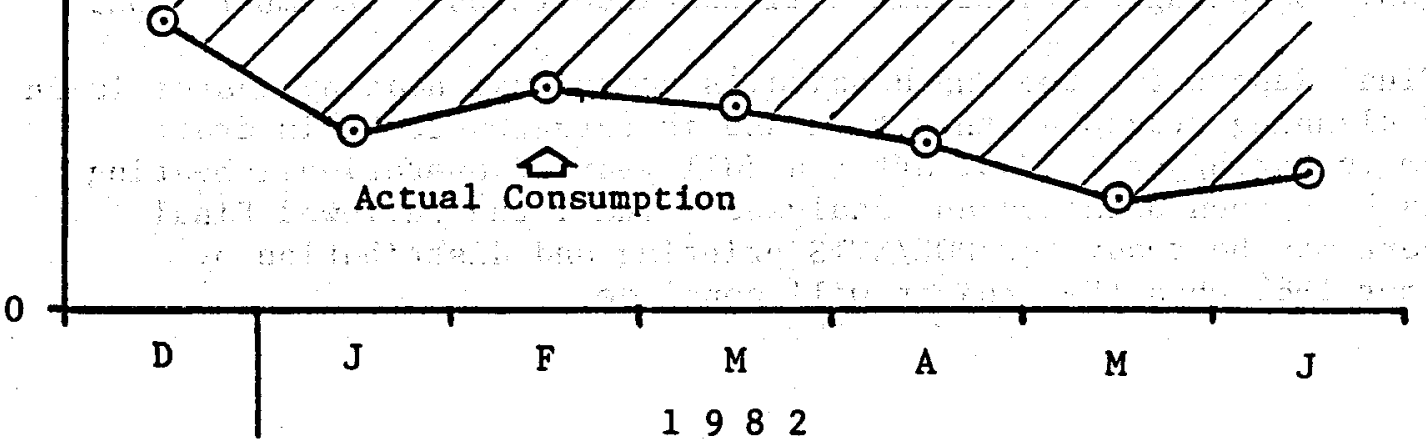

Figure 7. Initial Operational Gas Savings at THS Hospital 
THS MEMORIAL HOSPITAL

Marlin, Texas

On April 14, 1982, the THS Hospital's geothermal system was formally inaugerated and for this event-and any future inquiries-a four-page brochure was designed and produced. Both the overview and system diagram in this brochure are reduced-size versions of two framed renderings which now hang in the hospital's lobby and form part of the public awareness segment of the project.

An additional important portion of the public awareness objective is an automated audio/slide presentation that will be shown to interested visitors and can be easily taken to gatherings. This 20-minute show has been written for the average citizen and gives basic geothermal concepts and the THS Hospital geothermal system specifically. It is designed to inform, educate, and inspire others to employ lowtemperature geothermal energy in direct utilization projects.

In July 1982, two of four cascading plate heat exchangers (PHX) will be opened for inspection and/or cleaning. Since the PHX's will have experienced about a year of geothermal fluid contact, it is essential to establish a baseline inspection with regard to scaling (fouling) of the plates. Naturally, summertime is the ideal time for this inspection. Little, if any, fouling is expected due to the water characteristics and the closed geothermal fluid circuit concept. Any fouling that may be present can be removed via a laundry brush and detergent. However, heating rates have not indicated decreased heat transfer due to fouling of the plates. The remaining two $\mathrm{PHX}^{\prime}$ 's contain environmentally sensitive chromate corrosion inhibitors in the secondary loops and, therefore, will be opened only if reasonable indications are found in the first two PHX's.

In July, a materials test program was initiated to expose various metallics and non-metallics to at least a 90-day test program in the Marlin geothermal fluid. The results of this test will be made available to all potential users of this large, Central Texas resource.

To ascertain the exact degree of interaction between the geothermal surface discharge and the environment, a monitoring program has begun. Sampling and analysis will continue through December 1982.

A Final Report for the THS Hospital's geothermal heating system is in the planning stages at this time and is targeted to be in draft form in March/April 1983, after a full year of operational heating data have been obtained and analyzed. Thus, the reviewed Final Report may be ready for DOE/NTIS printing and distribution by Summer 1983 when the project will conclude. 


\section{PROJECT COST:}

The total approved project cost is $\$ 995,900$. This amount was underwitten in the following manner:

\section{SOURCE}

PERCENT

- US Department of Energy

- Texas Energy and Natural Resources Advisory Council

- In-Kind Services by the THS Memorial Hospital and City of Marlin

\section{LESSONS LEARNED: .}

1. The number of permits required and the effort necessary to obtain them were significantly underestimated in the initial project planning.

2. There is no standard method of economic analysts. The assumptions used to arrive at any payback period or rate of return must be highly qualified to understand its significance.

3. The amount of time and effort required to turn a final design which is complete in terms of an engineering review into an acceptable bid package was much greater than expected. Overall, the time and effort required to get from completed design to negotiated construction subcontract was greater than planned. Intermediate steps were: generate bid package, reproduce and issue package, advertise, answer questions, evaluate bid, investigate contractor and negotiate to get final signed subcontract. 
T-H-S MEMORIAL HOSPITAL

(Contract No. DE-AC08-78ET27059)

1. Klemt, William B., Robert D. Perkins, and Henry J. Alvarez, Ground-Water Resources of Part of Central Texas with Emphasis on the Antlers and Travis Peak Formation, Volume I, Report 95, Austin, Texas. Texas Water Development Board, November 1975.

2. Radian Corporation, An Environmental Report for the Geothermal Direct Utilization Project at the Torbett-Hutchings-Smith Memorial Hospital, Marlin, Texas, DCN 78-200-300-02 (Rev. A), Contracts DOE/ET-78-C-08-1554 and TENRAC/G-3-1, August 15, 1978.

3. Radian Corporation, An Exhibit for a Special Request for Exception to SWR 8 to Permit off-Lease Discharge of Geothermal Water at the TorbettHutchings-Smith Memorial Hospital at Marlin, Texas, Contract DOE/ET-78C-08-1554, November 13, 1979.

4. Radian Corporation, Preliminary Design Report for the T-H-S Memorial Hospital Geothermal Heating System at Marlin, Texas, DCN 79-212-300-15, Contracts DOE/ET-78-C-08-1554 and TENRAC/G-3-1, December 20, 1979.

5. Radian Corporation, Final Design Report for the T-H-S Memorial Hospital Geothermal Heating system at Marlin, Texas, DCN 80-212-300-16, Contracts DOE/DE-AC-08-78ET27059 and TENRAC/G-3-1, September 17, 1980.

6. Railroad Commission of Texas, Exception to Statewide Rule 14(B)(2), T-H-S Memorial Hospital, Inc., $(02282)$ Lease, Well(s) No. 1, Wildcat Field, Falls County, Texas, Letter, July 7, 1981.

7. Texas Air Control Board, Permit Exemption X-2672 Geothermal Heating Facility, Marlin, Falls County, Letter, August 3, 1981.

8. Texas Department of Health, Torbett-Hutchings-Smith Hospital \#517, Marlin, Texas HFC-AH80-0401-021, Review, Letter, May 15, 1981.

9. US DOE, Environmental Assessment, Geothermal Direct Heat Project, Marlin, Texas, DOE/EA-0117, August 1980 .

10. US DOE, Environmental Assessment DOE/EA-0117, Geothermal Energy, Direct Heat Applications Program, Torbett-Hutchings-Smith Memorial Hospital, Marlin, Falls County, Texas (July 1980) and Findings of No Significant Impact, Letter, August 8, 1980 .

11. US EPA/Region VI, NPDES Determination, Permit TX0086321, May 13, 1981.

12. THS Memorial Hospital, Geothermal Demonstration Brochure, Marlin, Texas, April 14, 1982. 


\section{PROJECT TITLE}

Direct Utilization of Geothermal Energy in

Western South Dakota Agribusiness

(Diamond Ring Ranch Geothermal Demonstration Project)

PRINCIPLE INVESTIGATOR

Dr. S. M. Howard - (605) 394-2341

Professor of Metallurgical Engineering

South Dakota School of Mines and Technology

Rapid City, South Dakota 57701

\section{PROJECT TEAM}

South Dakota School of Mines and Technology

Rapid City, South Dakota

Stanley M. Howard

Dan D. Carda

$\mathrm{RE} / \mathrm{SPEC}$, Inc. (Design)

Rapid City, South Dakota

Thomas Zeller

Bill Grams

Diamond Ring Ranch (Site Owner)

Midland, South Dakota Gene Armstrong

\section{PROJECT : OBJECTIVE}

The objective was to utilize an existing geothermal well to

1) product hot air for grain drying in a conventional grain dryer and

2) produce hot air for space heating four homes, a shop, and a hospital barn.

\section{RESOURCE DATA}

We11 Depth: $4112 \mathrm{ft}(1253 \mathrm{~m})$

Date Complete: 1959

Completion Technique: Open hole

Wellhead Temperature: $152^{\circ} \mathrm{F}\left(67^{\circ} \mathrm{C}\right)$

Flowrate: $170 \mathrm{gpm}(10.7 \mathrm{\ell} / \mathrm{s})$ artesian 
Summary: The Madison Aquifer extends under the western half of South Dakota and into the bordering states of Wyoming, Montana, and North Dakota. Most Madison wells in South Dakota are naturally flowing with temperatures varying from $110^{\circ} \mathrm{F}\left(43^{\circ} \mathrm{C}\right)$ to $170^{\circ} \mathrm{F}\left(77^{\circ} \mathrm{C}\right)$. Figure 1 shows the Madison's extent and temperatures in South Dakota.

\section{SYSTEM FEATURES}

Application: Space heating and grain drying

Heatload (Design): $3.35 \times 10^{6} \mathrm{BTU} / \mathrm{hr}$ (.98 MW)

Yearly Utilization (Maximum): $7.87 \times 10^{9} \mathrm{BTU} / \mathrm{yr}(.26 \mathrm{MW}-\mathrm{Yr}$ )

Energy Replaced: Electricity - 185,288 KWH/yr

$$
\text { Propane - 49,415 gal/yr }
$$

Facility Description: 6 bldgs. and a 700 bu/hr grain dryer use geothermal water with disposal to stock watering pond.

Summary: Two stainless steel plate-type heat exchangers are used to heat recirculating water. One of these exchangers is located at a 700 bushel/hr grain dryer and one in the shop. The exchanger at the grain dryer supplies a hot, inhibited propylene glycol-water mixture to a water-to-air exchanger through which the grain dryer fan pulls hot, dry air. Unlike conventional combustion grain dryers, the moisture content of the air is not increased as a consequence of heating.

The exchanger in the shop is used to heat water recirculating in two conventional hydronic loops supplying water-to-air exchangers. One loop feeds the two mobile homes and the hospital barn. The second loop feeds the shop, owner's home, and the employee's home. Temperature sensors at each end-use exchanger can start the recirculating pump in the shop to maintain hot water in each line. This reduces the response time when the space thermostat calls for heating. 
Inhibited ethylene glycol was added to the space heating loops after two winters in which the system froze during power failures.

Figure 2 is a schematic of the system layout. BTU meters were installed at the mobile homes, shop, employee's home, owner's home, and hospital barn.

\section{STATUS}

The grain drying system is operable and provides hot air for grain drying as designed.

The space heating loop operated normally during the 1979-80 winter and until February of the 1980-81 winter at which time a power failure caused freezing in the nomally recirculating water lines causing the rupture of two water-to-air exchangers. The repaired exchangers were reinstalled in September 1981. The system operated normally during the 1981-82 heating season.

The BTU meters installed during the last heating season indicated that the design capacity of the space heating units was achieved.

\section{CURRENT ESTIMATED PROJECT COST \\ Total : $\$ 403,098$ \\ DOE Share: $\$ 250,725 \quad$ Participant Share: $\$ 152,373$ \\ $62 \%$ \\ $38 \%$}

\section{LESSONS LEARNED}

1. The 4,000-ft. long pipeline carrying geothermal water to the isolation heat exchangers has three high spots along its length which could have been avoided only at greatly increased pipeline expense. A degasser at the wellhead proved insufficient to prevent gas pockets from forming in the line's high spots. This problem was eventually overcome by installing PVC air vent valves at the first two of the high spots. 
2. The space heating system is comprised of a plate-type isolation heat exchanger used to heat recirculating water to six structures: four homes, a hospital barn, and a shop building. These structures are supplied by two loops with the return water mixing as it re-enters the isolation exchanger. The problem of freezing arises in the event of a power failure. Freezing is most likely in the barn and shop since these structures have low thermal mass unlike the homes. To prevent freezing, the recirculating system was: charged with antifreeze. The cost of the antifreeze would have been substantially reduced by use of smaller recirculating lines ( 2 inch rather than 3 inch) and by dividing the isolation exchange into two units so as to put the structures subject to freezing all on one loop. It should be noted that this would have increased the capital cost but lowered operating cost assuming the antifreeze is lost several times during the system's life.

3. All systems using recirculating water subjected to freezing temperatures should be protected with antifreeze. One should not rely on auxiliary power or trained personnel to drain threatened equipment. This is particularly true for projects in remote locations such as the Diamond Ring Ranch.

4. Dividing the exchangers as described above would also have allowed subjugating the heating demands of the barn and shop to the other space heating demands. This would be a distinct advantage since the ambient temperatures of those structures are lower.

5. Screens should be placed directly before all positive-displacement flow meters (such as those required by many BTU meters). During the course of this project foreign matter lodged in the meters completely stopping the flow. 


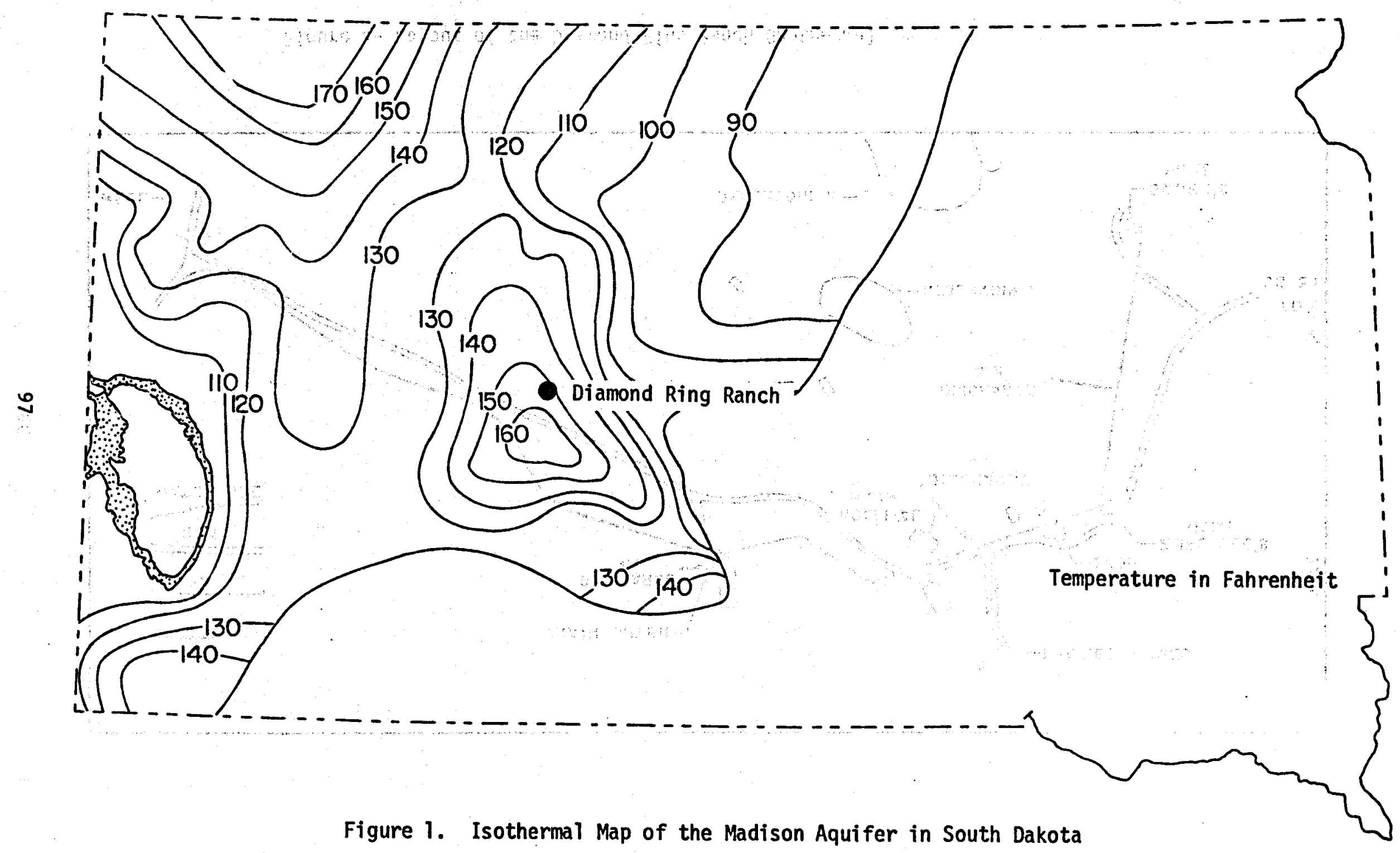




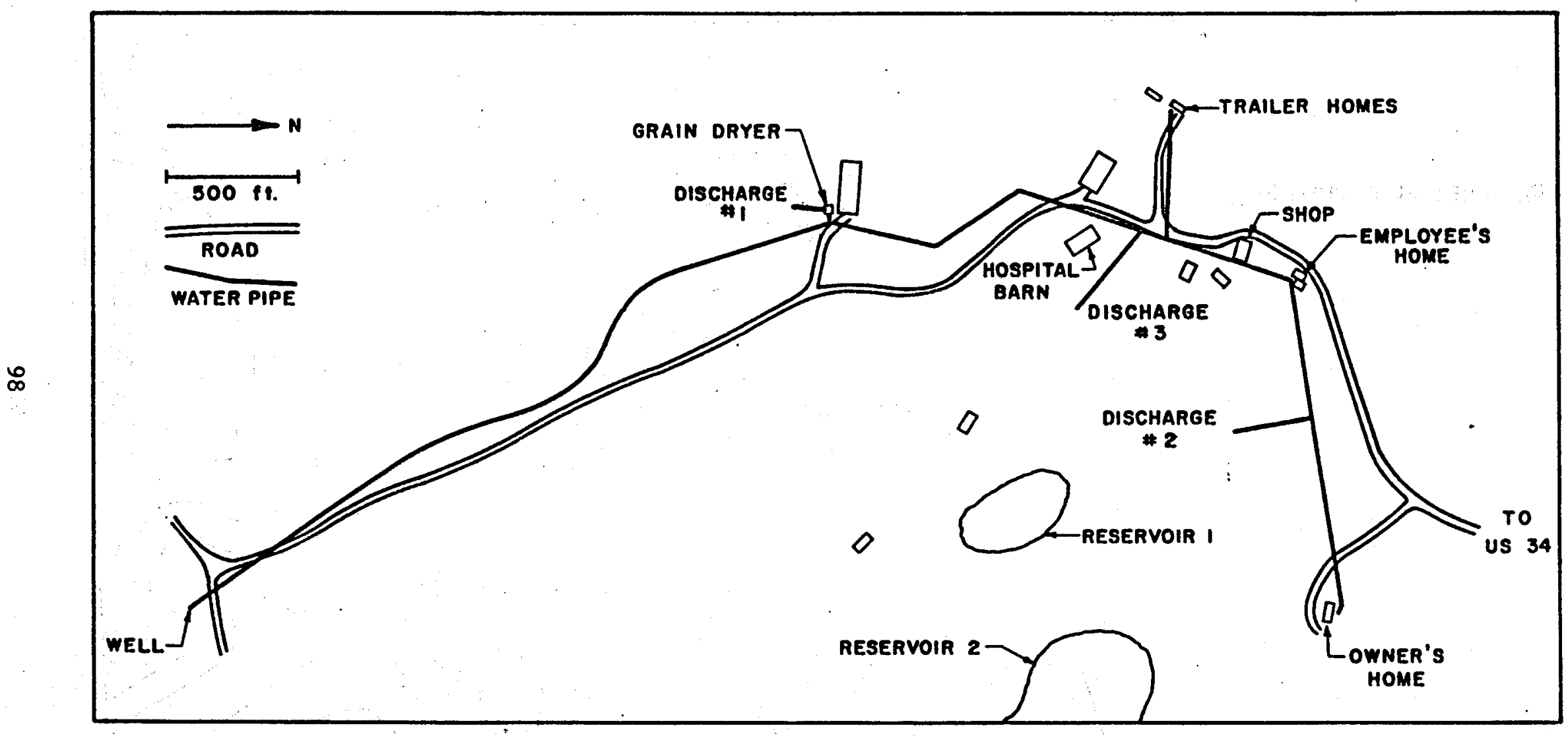

Figure 2- Layout of the Diamond Ring Ranch Geothermal Project 
Geothermal Direct Heat Application

St. Mary's Hospital

Plerre, South Dakota

\author{
Principal Investigator \\ James Russell, Administrator \\ Dale Moss, Director of Support Services \\ (605) 224-3100
}

\title{
Project Team
}

Kirkham, Michael and Associates, Engineers

Sherwin Artus, Reservoir Consultant

Dr. J.P. Gries, Geologist 
I. PROJECT DESCRIPTION

\section{Resource}

This project is located in central South Dakota within the City of Pierre. The Hospital served by the Geothermal well is located on the south side of Pierre approximately 1,000 feet north of the Missouri River which flows around the south edge of the city. The Geothermal energy will be utilized in an $83,000 \mathrm{sq}$. ft. existing hospital and also in a $65,000 \mathrm{sq}$. ft. hospital addition which is presently under construction.

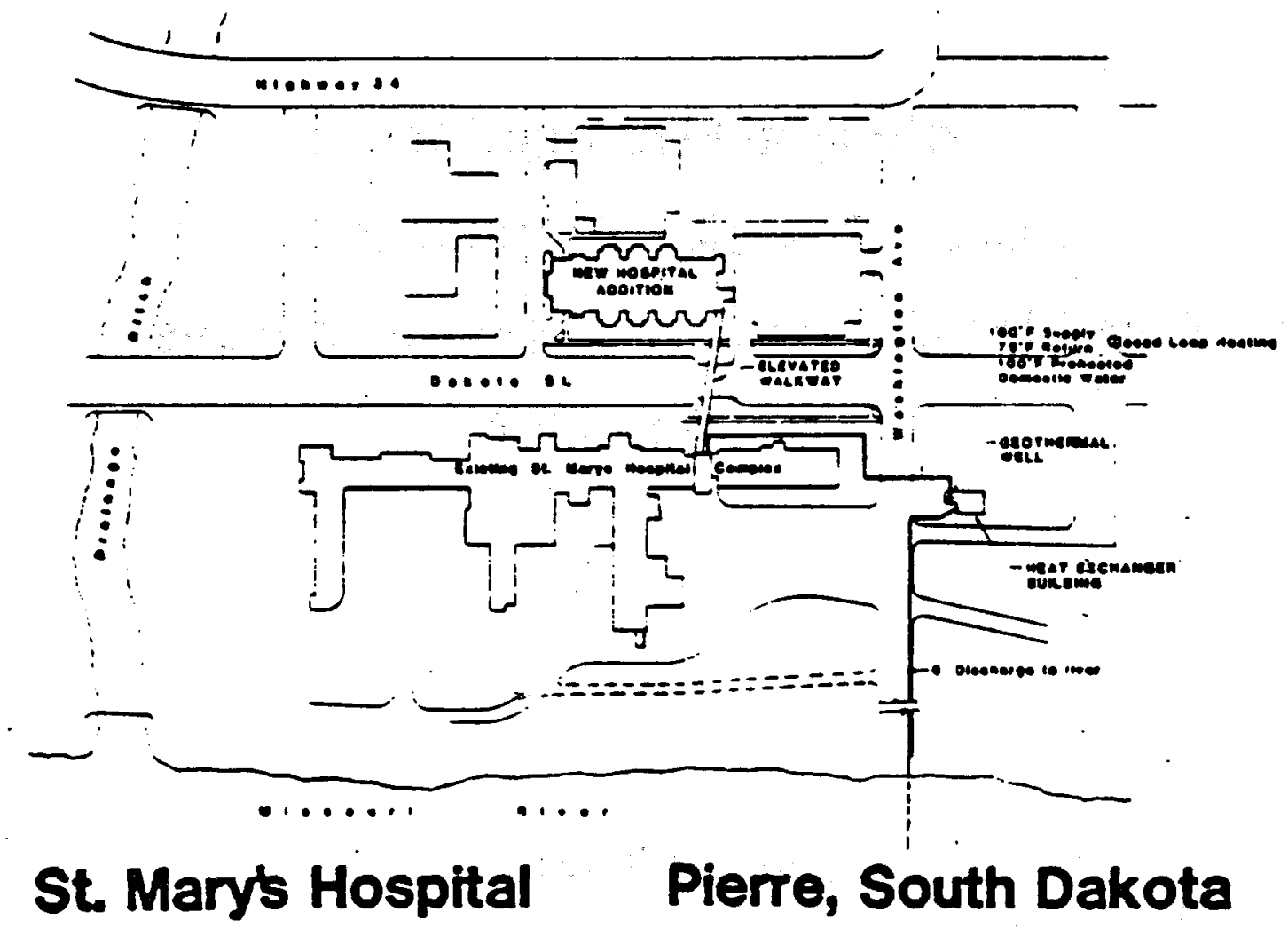

The well is located on hospital property in a vacant lot across the street east from the hospital. The well is drilled to a depth of 2,174 feet into the Madison aquifer.

The temperature of the water out of the well is $106^{\circ} \mathrm{F}$. The well flow is artesian and flows at a rate of 375 gallons per minute with a residual pressure of 27 psig at the well head. The pressure at the well head with zero flow obtains a maximum of 480 psig. 
The water from the well has a total dissolved solids of 2,084 ppm and a hydrogen, sulfide content of 0.7 ppon. Complete water analyols as lollowe:

TABLE I , WATER ANAYYSIS FOR ST. MARY'S WEL

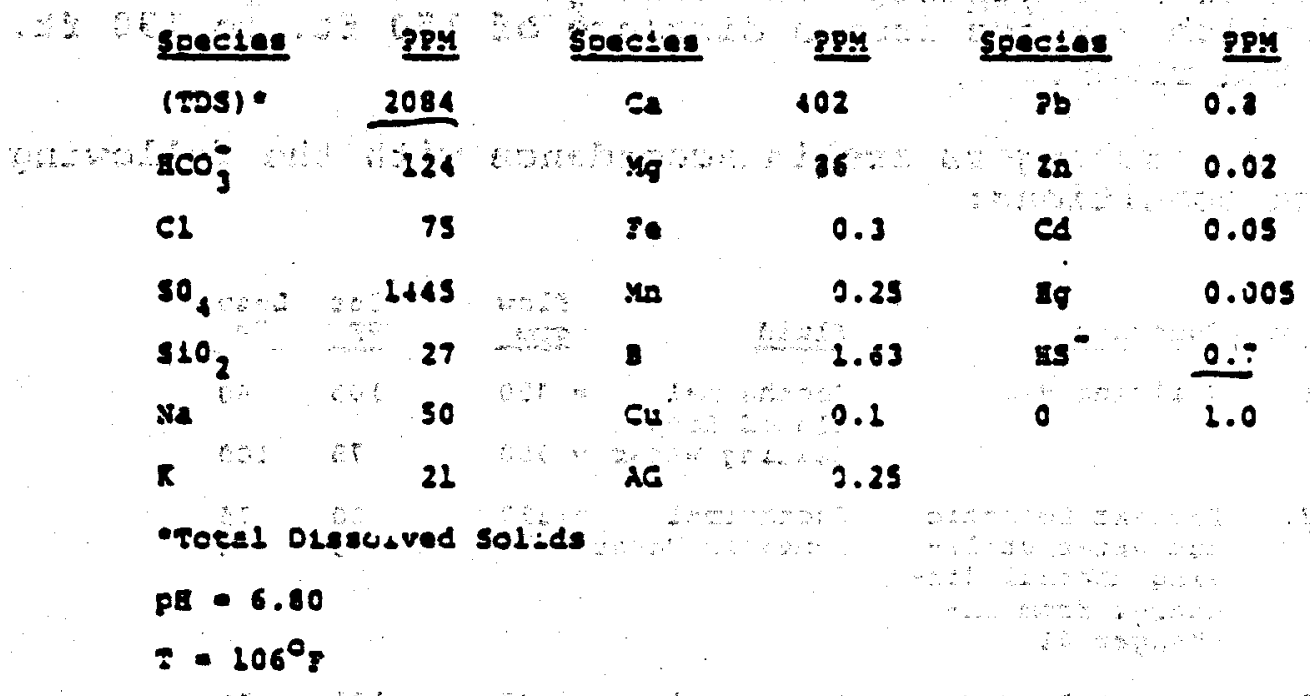

\section{Design}

The heat is extracted from the Geothermal water by three heat exchangers located inside a small building at the well site.

The heat used from Heat Exchanger 1 is by a closed loop system girculated by a centrifugal pump which delivers $100^{\circ}$. to the bullding heating systems.

The domestic water, which is preheated by leat Exchangers 1 and 2 , is stored in an insulated 4,000 gallon tank located within the heat exchanger building and made available for use upon demand.

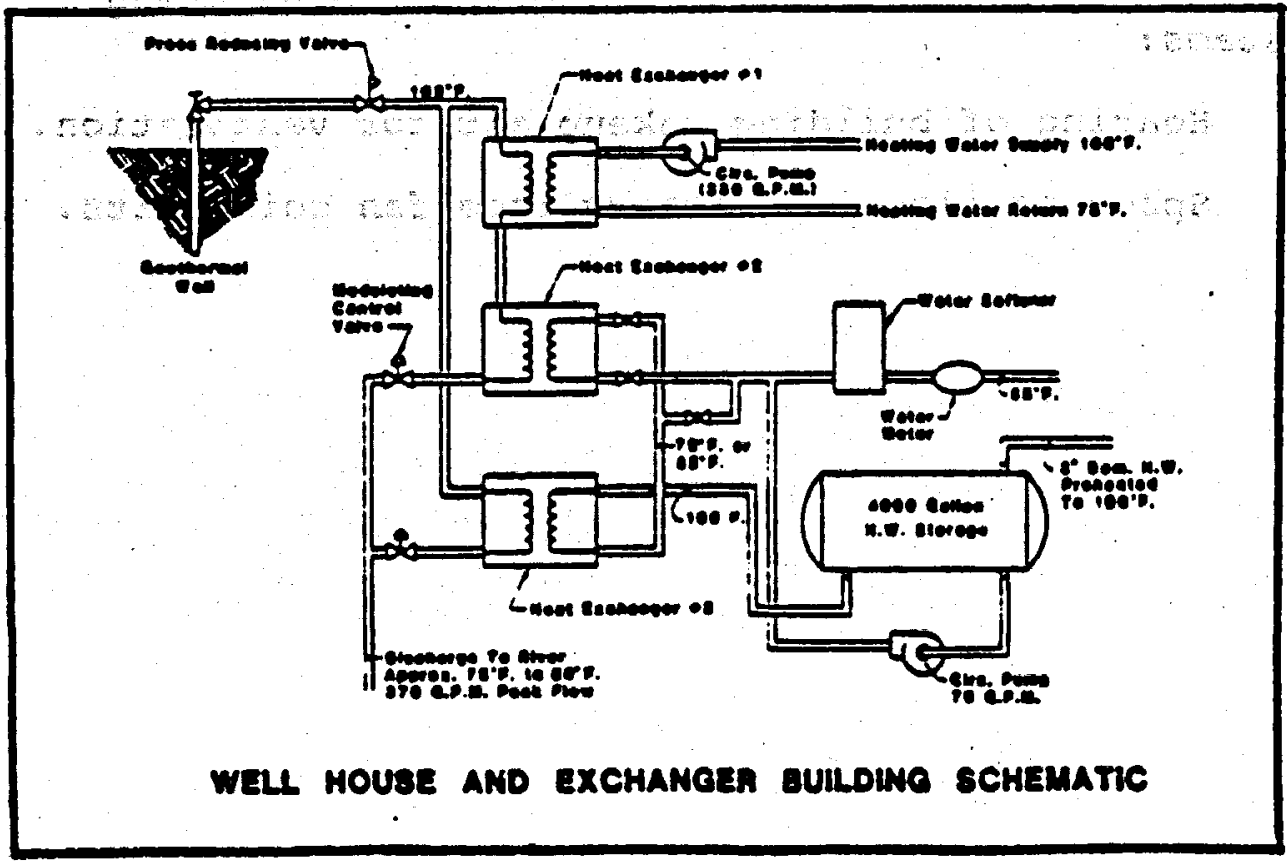


The well water discharged from the heat exchangers 18 directed through a 6 in. poly vinyl chloride pipe approximately $1.100 \mathrm{ft}$. south to the Missouri River. The water will be dispersed through $40 \mathrm{ft}$. of perforated pipe which extends from a distance of $150 \mathrm{ft}$. to $190 \mathrm{ft}$. into the river.

The heat exchangers are in accordance with the following design conditions:

\begin{tabular}{|c|c|c|c|c|c|c|}
\hline wo. & Eupceion & Fluid & $\begin{array}{l}100 \\
9720\end{array}$ & & ogt & of \\
\hline 1. & Building geat & $\begin{array}{l}\text { Goothermal } \\
\text { closed toop } \\
\text { geatung Water }\end{array}$ & $\begin{array}{l}-350 \\
-350\end{array}$ & $t$ & $\begin{array}{r}105 \\
75\end{array}$ & $\begin{array}{r}10 \\
100\end{array}$ \\
\hline 2. & $\begin{array}{l}\text { Prohest Domestic } \\
\text { bot water ueidi- } \\
\text { zigg ehermal dis- } \\
\text { charge from Ex- } \\
\text { changer il }\end{array}$ & $\begin{array}{l}\text { Goovhermal } \\
\text { Domaste Water }\end{array}$ & $\begin{array}{r}350 \\
=76\end{array}$ & & $\begin{array}{l}80 \\
55\end{array}$ & $\begin{array}{r}75 \\
78 \\
\therefore \quad\end{array}$ \\
\hline 3. & 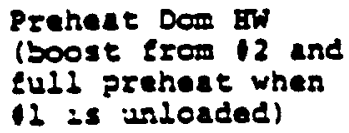 & $\begin{array}{l}\text { Georhermal } \\
\text { Domeseic water }\end{array}$ & $\begin{array}{l}97 \\
76\end{array}$ & & $\begin{array}{r}105 \\
55\end{array}$ & $\begin{array}{r}70 \\
100\end{array}$ \\
\hline
\end{tabular}

A corrosion and water quality report indicated that Type 316 stainless steel be the material used for the thin wall plate fin type heat exchangers.

End Use of Heat in Existing Rospital

The $100^{\circ} \mathrm{F}$. preheated domestic hot water is connected to the supply to the existing water heater and the existing hospital steam system provides further heating as required.

$\because$ The closed loop heating water serves two existing systems :

1.: Heating of building makeup ais for ventilation.

2. Space heating in existing room fan coil units. 
$155 \mathrm{gpm}$ of $100^{\circ} \mathrm{F}$. water from Heat Exchanger 11, representing 2,000,000 BTUH, is used in the new hospital addition. The new heating system is designed to utilize the Geothermal heat source.

The Geothermal energy is utilized directly in the hot deck coil of the main building aif handing units. As the outside temperature drops and the demand for heat increases, further energy is extracted from the Geo-。 thermal by directing a portion of the approximate $80^{\circ} \mathrm{F}$. return water from the hot deck into the chiller. Heat is then taken from the conjenser or hot side of the chiller in the form of $120^{\circ} \mathrm{E}$ warm water for use in individual space heating coils. This egndenser water is also utilized to add heat to the $100^{\circ} \mathrm{F}$. preheated domestife hot water to raise it to a final use temperature of $110^{\circ} \mathrm{F}$.

\section{System Economics}

Fuel oil is the present source of heat energy for st. Mary's Hospital. Energy from the Geothermal source is expected to reduce the hospital's future demand for fuel 011 by 115,000 gallons per year.

Based on a simple payback formula of initial cost divided by annual cost savings, the project economics are as follows: 
ECONOMIC DATA

- TOTAL PROJECT COST

$=\quad \mathbf{8 7 1 8 , 0 0 0}$

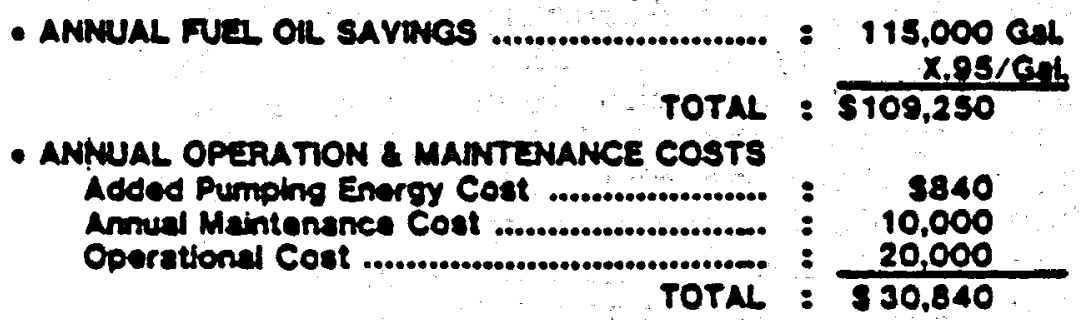

- OVERALL PRQLECT SHPLE PAYBACK

$\$ 712,000$ Total Cost

(\$ 100,250 Ammal Fual Seving - \$30,840 Oper.8 Maine Cost)

: 9.15 VeARS

- payback to ownera

25* SHARE OF TOTAL COST

$\frac{\$ 718.000 \times .25}{\$ 100,250 \cdot \$ 30,840}: 2.3$ rEAAS

The flow demand on the well will vary in direct relation to the system demand for energy from a peak requirement of approximately $360 \mathrm{gpm}$ during the coldest winter month to approximately 96 gpm during the sumer for domestic hot water preheating. The calculated total annual well water consumption is 51.1 million gallons.

II. STATUS

The well was completed in April of 1979. The original flow rate was approximately $250 \mathrm{gpm}$. After further perforations of the well casing and by pumping 8,000 gallons of 20 percent ECI solution into the well, the flow rate was increased to the present level of 375 gpm.

The construction work for the application of the Geothermal resource to the existing hospital and the new addition was completed september, 1980. The systems were put into operation in mid October of 1980. System performance when put into operation exceeded the anticipated capability as follows:

Anticipated

Well supply Temp. $=106^{\circ} \mathrm{F}$

Closed Loup Supply Temp. $=100^{\circ} \mathrm{F}$

Domestic Hot iater Supply $=100^{\circ} \mathbf{F}$
Actual

$108^{\circ} \mathrm{F}$

$104^{\circ}$ to $105^{\circ} \mathrm{F}$

$106^{\circ} \mathrm{F}$ 
During the first year of operation (1980-1981 heating season) irecords from St. Marys Hospital's support services division indicated a net fuel savings of 60,000 gallon over that anticipated without the use of geothermal energy.

During the second year of operation (1981-1982 heating season) the... geothermal system was out of service from December 1981 through March 1982, due to severe corrosion in the geothermal water supply pipe. The flow from the well is artesion and with pressures up to 480 psig under low flow conditions. A pressure reducing valve is provided of $f$ the well head to provide 75 psig operating pressure to the system heat exchangers. The corrosion occurred in the schedule 40 steel piping system between the pressure reducing valve and the heat exchangers.

Corrosion analysis were then made by the Radian Corp of Austin. Texas. This analysis concluded that carbon steel pipe was not compatible with the chemistry of our geothermal water, and recommended the use of PVC or reinforced plastic pipe.

approximately 120 feet of distribution pipe was replaced with plastic pipe reinforced with glass filament windings.

During this second year of operation there were approximately 10,000 annual heating degree days versus an average for Pierre, SO of 7611. $52 \%$ of these heating degree days occurred when the system was out of service. The operating personnel estimate that the total savings this second year would have been 123,228. gallon of fuel oil had the system been fully operational. Our original study projected an annual fuel savings of 115,000 gallons. It appears that we need to wait for one more year of operation for a true evaluation.

All phases of the system have functioned adequately and virtually problem free except for the pipe replacement. $f$ 


\section{LESSONS LEARNED}

1. An economic space-heating system with good payback can be obtained with only a $106^{\circ} \mathrm{F}$ geothermal resource.

2. The flat plate and frame heat exchangers have worked very well and the project's A/E firm uses them more often now than previously.

3. The preinsulated reinforced fiberglass pipe (PVC cover over eurethane insulation) performed satisfactorily in this application.

4. The Madison Aquifer in this region, apparently will not produce more than $400 \mathrm{gpm}$ even after stimulation of the well by acidizing, and therefore, the well and system designs should be scaled to this flow limit per well.

5. The design of the well should permit later protection of the interior surfaces of the casing from corrosion.

6. The design and the materials used for pipin!l and other components should be selected to minimize corrosion dus to exposure to the geothermal water. Material coupon tests should be performed in the specific geothermal fluid which will be used.

7. When discharging fiuid into a river from a perforated pipe along the bottom of the river, do not shut off the discharge for more than two days at a time. Silting over of the pipe may force mechanical removal before discharge can be restarted.

8. Find out about, and make allowances for, permitting requirements as early in your project planning as possible.

9. Provide a contingency in any drilling budget since it is unlikely drilling will go according to plan except within a well established drilling field. 
PROJECT TITLE: Project of Raising Prawns with Geothermal Water in the Cochella Valley, California.

PRINCIPAL INVESTIGATOR: Dr. Dov Grajcer, Aquafarms International Inc. (AII)

PROJECT TEAM: Rick Visoria, DOE, Oakland

Ken Zahora, DOE, Oakland

Dr. Dov Grajcer, President, AII

Rebecca Broughton, Deputy Project Director

AII's Technical Staff: Vincent Price

Bruce Jackson

Mary Price

steve Fulks

Stanley Fulks

Dr. Tsvi Meidav, Geotherma l Consul tant, Meidav Assoc.

Kreiger Inc, Accounting, Palm Desert

PROJECT DESCRIPTION:

Aqua farms International, Inc., a small California corporation, has developed a 50 acre prawn farm on its property in the Dos Palmas area, on the east side of the Cochella Valley. By utilizing geothermally heated water, All conidacts a continuous, year round prawn farming operation.

The specie of prawns being grown is Macrobrachium rosenbergif. Figure 1 shows the layout of the ponds.

\section{LOCATION DESCRIPTION:}

AII's headquarters is located off of Callfornia State Highway 111 , near North Shore (mafling address: P.O. Box 157. Mecca, CA 92254). DOE project sité 105555 Ave 74 , Cochella valley, CA.

\section{RESOURCE DATA:}

WELL A-1*:

The well was drilled to 910 feet during january 1980. It was completed with 1 -inch diameter casing since it was specifically constructed as a thermal gradient hole. Geophysical logging was conducted including: S.P., resistivity and gamma-ray. Thermal gradient measurements were al so made. The thermal gradient actually measured was more than twice the mean global thermal. gradient, i.e., over $75^{\circ} \mathrm{C} / \mathrm{km}\left(4.1^{\circ} \mathrm{F} / 100 \mathrm{ft}\right)$. This indicated that a favorable thermal gradient for direct heat uses extends all the way' to the north end of the property. On the other hand, the pleziometric surface at the north end is about il feet below the ground surface; therefore, pumping is required. 
WELL A-2:

This well was drilled to 100 feet during February 1980 . Attempts to control the artesian flow with a high-density barite-rich drilling fluid failed because of inadequate pumping capacity. To prevent a potential collapse of the hole, it was decided to develop it as an agricultural well, rather than a geothermal well. A $15 \mathrm{hp}$ centrifugal pump has been installed at this location. The water temperatue for this well is $82^{\circ} \mathrm{F}$.

WELL F-1:

This well was drilled to a depth of 325 feet during June 1980 . The well was completed with a double casing to two depths, as two distinct water temperatures were available at two separate depths. The greater flow, located at the shallower depth, was $79^{\circ} \mathrm{F}$. The deeper portion has been fitted with a $7.5 \mathrm{hp}$ centrifugal pump, in order to utilize the $92^{\circ} \mathrm{F}$ water during cold climatic conditions to maintain the critical life temperatures for the prawns. The advantage of this well is that the cooler water can be used year round; undiluted during normal periods and as diluent water for moderating the temperature of the high temperature section when necessary.

WELL F-2:

This well was completed to 180 feet during. July 1980 . Water from this well $\left(83^{\circ} \mathrm{F}\right)$ can be pumped through a series of pipes to ponds constructed during the project period. This well was drilled, cased, cemented and redrilled through the cement cap; allowing maximum control of the artesian flow. Its water chemistry nearly duplicates that of Well A-2. Water from this well is currently being utilized to support an actively growing prawn population.

WELL F-3:

This well was drilled to a depth of 800 feet during July 1980. The best geothermal potential exists at this site, wellhead temperature was $107^{\circ} \mathrm{F}$. Well cave-in occurred and attempts to redevelop the well did not succeed. The site is being held for future consideration.

WELL F-4:

This well was drilled to 125 feet during February 1981. Water temperature was $86^{\circ} \mathrm{F}$. Water from this well is currently being used to maintain grow-out ponds located on the southeast portion of the site. 
WELL TF:

This well was originally fnitlated as A-1 in January of 1980. However, due to squeeze clay effects and partial hole collapse, drilling was halted, and a new $A-1$ site was chosen $\left(A-1^{*}\right)$. Because of information gathered previously, the site was redeveloped as an agricultural well. It has been cased to 100 feet and a submersible pump installed.

\section{SYSTEM FEATURES:}

APPLICATION: The water is being used directly to supply ponds for the prawn grow-out facility.

YEARLY UTILIZATION: The geothermal fluid must be used throughout the year as the desert is subject to extreme temperatures, as well as extreme temperature fluctuations. This use of the geothermal fluid will enable these temperatures to be mitigated.

ENERGY REPLACED: If fossil fuels were to be used to heat irrigation water, a total of 170 billion Btu/Yr would be requied per year for a 50 acre farm. As the pond heating is to be $100 \%$ geothermal, that amounts to approximately 30,360 barreis heating fuel/yr (heat value $5.6 \times 10^{6} \mathrm{Btu} / \mathrm{bbl}$ ) replaced.

FACILITY DESCRIPTION: The prawn grow-out facllity is located on approximately 250 acres of land. The northern part of this area has been developed into 50 acres of ponds. Seven wells have been completed during this contract, two of which are double cased. However, three additional wells exist which predate the contract. The water from these wells is distributed via a piping system to the prawn ponds. Where approprlate, ponds include valved delivery systems and drop box drainage systems. Pond banks act as both impoundment features and roadways. Electricity is available to all pumping sites. A drive through, low maintenance feed storage factlity was constructed. Other equipment necessary for daily operations includes: pond maintenance equipment, portable feed containers, harvest nets (several types), aerated transfer/transport systems and water quality monitoring equipment. 
DISPOSAL METHOD: When AII's water resources reach a point that a disposal procedure must be adopted, several techniques can be employed. Much water is lost to evaporation and some is percolated through the pond substrate. Surplus water could be impounded and recycled.

SUMMARY: With the direct use of geothermal water it seems to be possible to develop an economically sound 50 acre prawn farm in the Cochella Valley, California. At today's prices this project is not feasible if fossil fuel were used because the gross product income is less than the cost of the fossil fuel.

STATUS:

A substantial schedule slippage was caused early in the contract by a very slow reaction to and often ambiguous requirement of various environment related agencies. Therefore, in order for a cost overrun not to be incurred, AII, with cooperation and advice from the DOE, chose a time extension at no additional cost.. Through efficient management and a highly qualified total capability team, we have been able to complete some tasks under budget. The reserved funds were channeled into tasks in which inflation made the largest inroads. An extension to August 15 enabled us to complete facility development. The final handbook/report is being drafted.

\section{CURRENT ESTIMATED PROJECT COST:}

Total :

$\$ 575,266$

DOE Share:

$\$ 363,000$

Participant Share: $\$ 212,266$

\section{LESSONS LEARNED:}

1. Projects that are some distance from an agricultural or industrial center should plan, from the beginning, to include within their resident team persons capable of construction and maintenance. This assures satisfactory job performance, adherence to schedule, good response to project needs and helps minimize project costs.

2. Drilling and completing relatively shallow artesian geothermal wells was a problem for local water well drillers. This problem was resolved by setting and firmly cementing a 20 inch dia conductor casing from surface to $50 \mathrm{ft}$ depth. Local water well drillers needed to be educated on conductor casing use. 
3. Heat transfer losses were large and temperature was somewhat difficult to control with the original pond design (100 ft wide by $5 \mathrm{ft}$ deep and varying lengths from 300 to $800 \mathrm{ft}$ ). The surface area of new ponds has been cut in half ( 50 ft wide by $10 \mathrm{ft}$ deep and similar lengths). 


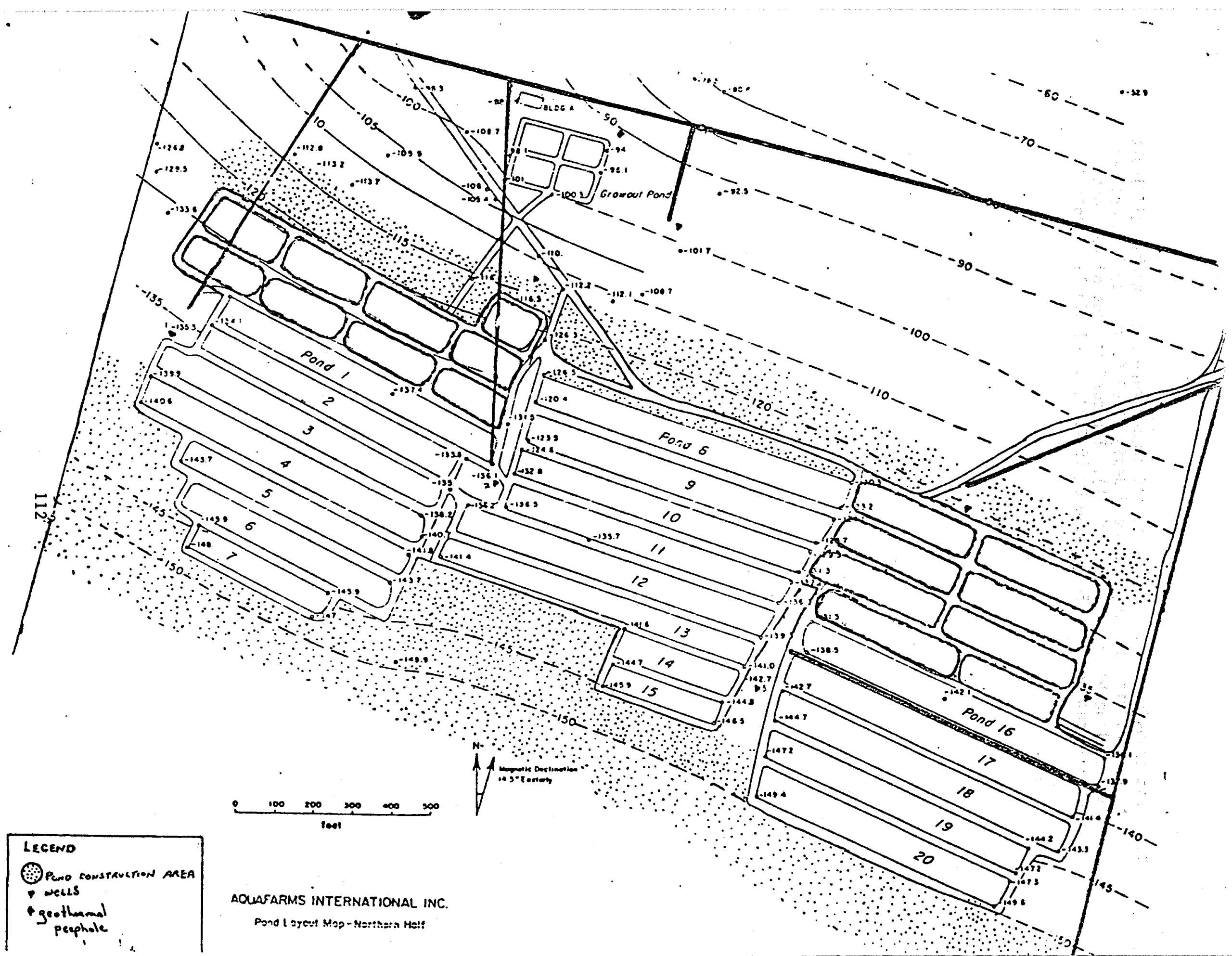




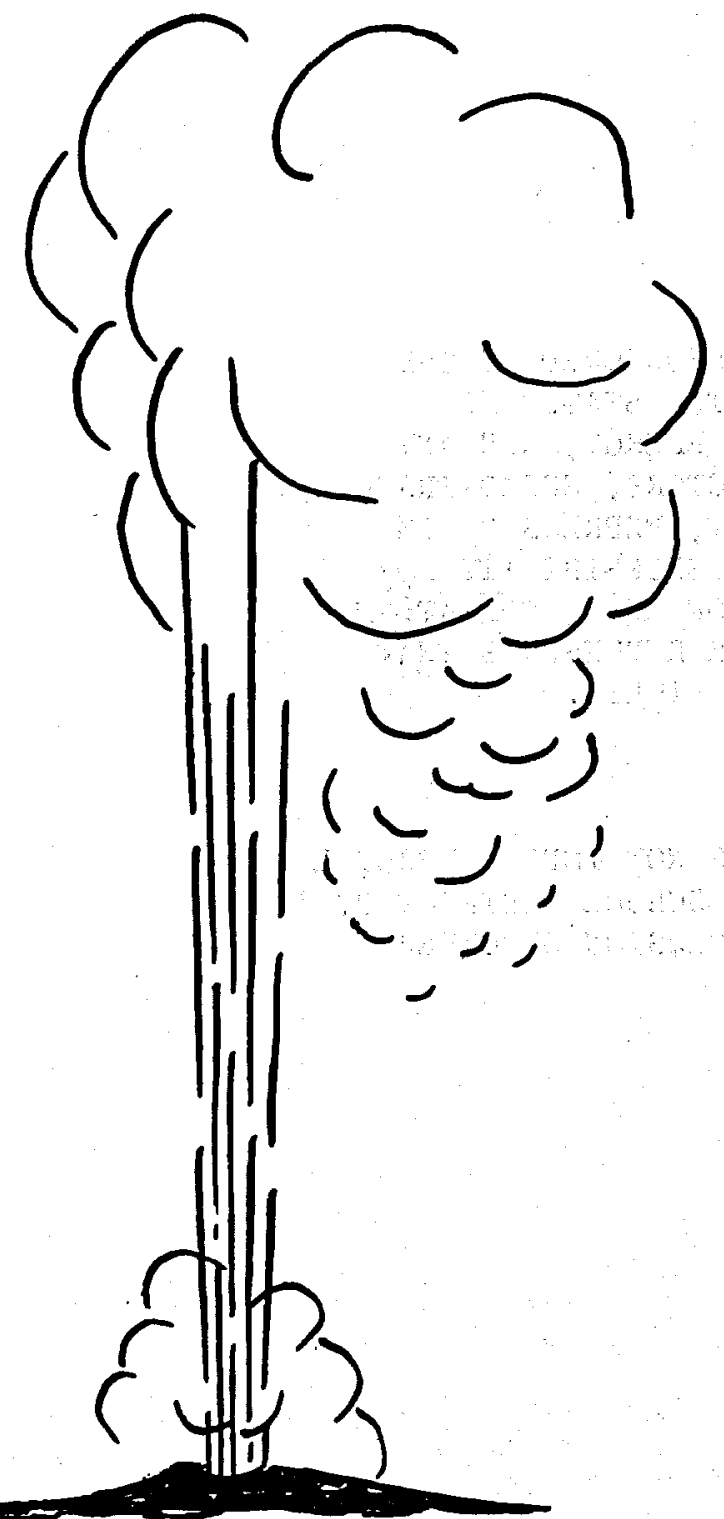

DIRECT UTILIZATION OF GEOTHERMAL

ENERGY FOR PHILIP SCHOOLS

PROGRESS REPORT TO

JUNE 30, 1982

CHARLES A. MAXON

RAYMOND J. HENGEL

JUNE 1982

WORK PERFORMED UNDER COOPERATIVE AGREEMENT NO. DE-FC07-78ET27080

FOR THE IDAHO OPERATIONS OFFICE

HAAKON SCHOOL DISTRICT 27-1

PHILIP, SOUTH DAKOTA

\section{U. S. DEPARTMENT OF ENERGY Geothermal Energy}




\section{NOTICE}

THIS REPORT WAS PREPARED TO DOCUMENT WORK SPONSORED BY THE UNITED STATES GOVERNMENT. NEITHER THE UNITED STATES NOR ITS AGENT, THE UNITED STATES DEPARTMENT OF ENERGY, NOR ANY FEDERAL EMPLOYEES, NOR ANY OF THEIR CONTRACTORS, SUBCONTRACTORS OR THEIR EMPLOYEES, MAKES ANY WARRANTY, EXPRESS OR IMPLIED, OR ASSUMES ANY LEGAL LIABILITY OR RESPONSIBILITY FOR THE ACCURACY, COMPLETENESS, OR USEFULNESS OF ANY INFORMATION, APPARATUS, PRODUCT OR PROCESS DISCLOSED, OR REPRESENTS THAT ITS USE WOULD NOT INFRINGE PRIVATELY OWNED RIGHTS.

\section{NOTICE}

REFERENCE TO A COMPANY OR PRODUCT NAME DOES NOT IMPLY APPROVAL OR RECOMMENDATION OF THE PRODUCT BY HAAKON SCHOOL DISTRICT 27-1 OR THE U.S. DEPARTMENT OF ENERGY TO THE EXCLUSION OF OTHERS THAT MAY BE SUITABLE. 


\section{ABSTRACT}

The primary objective of the Direct Utilization of Geothermal Energy for the Philip Schools was to obtain water that could be used to heat the Haakon School District Buildings located at Philip, South Dakota.

Henge1, Berg \& Associates, Architect-Engineers, of Rapld City, South Dakota, was the prime design consultants to the Haakon School District. Their preiliminary studies indicated that adequate volume of water of approximately $155 \mathrm{~F}$ could be obtained from the Madison Formation which underlies the area.

The demonstration project was developed in phases. The first phase was to drill a new well into the Madison Formation. This new well was located on property owned by the Haakon School District and is adjacent to the school buildings in Philip, South Dakota.

An environmental assessment report was prepared and submitted to the varlous agencies for review.

The well was completed to a total depth of $4266 \mathrm{feet}$. The metered rate of the artesian flow is a maximum of $340 \mathrm{gpm}$ of geothermal fluid at 157 degrees $F$.

The Barium Chloride treatment system was developed to remove the sulfates which contain Radium 226 and are naturally present in the geothermal fluid. A plant consisting of a building housing the treatment process equipment and a two-cell pond was constructed ahead of final discharge into the North Fork of the Bad River.

Nine businesses in the downtown Philip area inftiated a preliminary study to determine feasibility of heating their buildings with the 130 . F water discharged from the school system. These businesses are located along the route of the school water discharge 1ine. The study indicated that approximately one half of the heating requirements for these buildings could be obtained from the discharge water.

A two pipe system was designed and constructed through the business district area. The school discharge line is the supply line to the business heating district. A second line was installed to carry the return water after it passed through the business bullding.

The project was divided into two bid packages. One bid package included the piping at the wellhead, the distribution pipeline to the school buildings, the discharge pipeline from the school to the business district, the supply and return lines through the business district, the control system at the end of the business district, the discharge line from the business district to the treatment plant, the barium chloride treatment plant and the discharge line from the plant to the river. The total bid for this portion of the project was $\$ 490,700.00$. Negotiations were conducted to modify some of the contractural requirements and reduce the final price for the pipeline package to $\$ 436,685$. 
The other portion of the bid package included the geothermal conversion of the school heating systems and boiler replacement in the school buildings. The contract was awarded for a total of $\$ 346,500$. Through negotiations after award of contract and changes in construction during the construction phase, the final cost of the project was $\$ 331,029.00$. The construction phase of the project was substantlally completed November 17, 1980. Since that date the geothermal fluid has been used to heat all of the school buildings and their domestic water.

The modifications to the heating systems in the buildings that are part of the heating district are under contract but not complete. 
The primary objective of the project is to utilize the avallable heat from the water in the Madison Limestone Formation for space heating. Secondary objectives are:

1. Provide information to other potential users of geothermal heat energy.

2. Provide an energy source for other users in future development stages.

3. Conserve fossil fuel and electrical energy.

\section{SCOPE OF PROJECT}

A preliminary study performed by Hengel, Berg \& Assoclates for the Haakon School District 27-1 of Philip, South Dakota, Indicated that it would be feasible to heat the three school bulldings at Philip with energy from the Madison Formation geothermal fluid. This study was undertaken and completed in June of 1977.

Studies completed by the South Dakota School of Mines and Technology under the direction of principal investigator Dr. J. P. Gries and entitled "Geothermal Applications on the Madison Aquaf ir System in South Dakota" dated 1977, Indicates that the geothermal energy in the Haakon County South Dakota area could be used for space heating of buildings in this area.

The Haakon School District 27-1 did not have the available resources to implement the project. A proposal was submitted to the Department of Energy for matching funds to develop the geothermal resources. The estimated cost to complete the demonstration project is $\$ 1,202,499$ of which the Haakon School District $27-1$ will provide funding for $\$ 218,000$. The funding for the project is approximately 80 percent Department of Energy and 20 percent Haakon School District 27-1.

The new well under the first phase was drilled into the Madison Formation on property owned by the School District approximately 170 feet northwest of the armory-high school building.: After the completion of the well, volume and temperature were measured. A chemical analysis was completed on four samples. This information was used for the design of the heating system conversions.

The second phase involved the design and construction of the heating system conversions in the existing buildings. The buildings heated included an armory-classroom building that houses the high school classrooms and NatIona1 Guard Armory. This building is approximately 20,088 square feet in. area and 327,690 cubic feet in volume. A second bullding was an elementary grade school bullding that houses all of the classrooms and administrative offices. This building is approximately 15,356 square feet in area and 154,223 cubic $f e e t$ in volume. The armory and elementary school were previously heated with bollers that burned fuel oil. The boilers were steam bollers. The conversion of the heating systems in these buildings included changing the radiation units from steam to hot water systems. 
A third building was the vocational-agricultural-education building which contains a vocational-agricultural shop and four classrooms. The vocational-agricultural bullding is approximately 6252 square feet in area with 83,124 cubic feet of volume. This building was heated with electricity. The modification in this building included adding new hot water radiation units and modifying the ventilation system.

Two smaller buildings presently used for band and vocal music were added to the geothermal heating system. One building is approximately 1550 square feet in area and approximately 13,944 cubic feet in volume. The other building is approximately 792 square feet in area and approximately 6332 cubic feet in volume. These two structures were previously heated by propane fired space heaters.

The corrosive effect of the water from the Madison Formation required the use of a heat exchanger to separate geothermal fluid from the closed loop space heating water. The Madison Formation water was then discharged to the supply line of the downstream District Heating System.

The existing steam heating system in the armory and elementary buildings was modified so that the closed system hot water can be pumped to the modified $f$ in tube radiation units and modified fan coil units. New fan coil units were provided in the vocational-agricultural education building and in the band and vocal music buildings. The domestic hot water for the buildings will be heated with the geothermal fluid.

The initial proposal contemplated modifying the existing steam boiler system as a stand-by or back-up system by adding a steam to water heat exchanger.

The geothermal fluid was piped from the well to the High School-Armory Building and to the Elementary School building. The geothermal fluid is moved through the system using the pressure of the artesian flow.

The results of the corrosion tests indicated that the most satisfactory material would be stainless steel. Therefore, stainless steel plate type heat exchangers were used.

An analysis of the following plate type heat exchangers and combinations of heat exchanges was made:

a. A single heat exchanger for all school buildings on the site.

b. A single heat exchanger for the Armory-High School Building and a second heat exchanger for the Elementary and other buildings.

One heat exchanger for space heating and one heat exchanger for domestic water heating in the Armory-High School building and one heat exchanger and for space heating and one heat exchanger for domestic water heating in the Elementary School building to serve the Elementary building and the other adjacent buildings. The analysis indicated that separate heat exchangers for space heating and domestic water heating for each of the two buildings would be the most cost effective arrangement.

The geothermal water was divided on the ratio of approximately 190 GPM to the Armory-High School and 120 GPM to the Elementary School. All of the 
water passes through the heat exchangers before being discharged to the district heating system supply line. Nine buildings are now included in the district heating system.

Sulfates containing the Radium 226 are removed at the treatment plant by adding barium chloride to the geothermal water and discharging the water in one of the two ponds where the sulfates precipitate.

The scope of the project was increased by the request of several owners of business buildings along the route of the discharge line. These business men pald for a study to determine the feasibility to use the heat remaining in the water after leaving the school to heat their buildings.

Testing has indicated that Radium 226 is present in the water. To remove the Radium 226 from the water, the scope of the project was increased to provide for a Barium Chloride Treatment Plant.

\section{SEQUENCE OF EVENTS}

A contract was negotiated between the Haakon School District 27-1 and the Department of Energy, and the work was performed under this contract.

An Environmental Assessment Report was prepared. This report was submitted to the Department of Energy for review and comment. This review was completed with the Department of Energy making some minor additions to the report. An updated addendum to the Environmental Assessment Report has been submitted to the Department of Energy.

The plans and specifications for the well were prepared by Francis-MeadorGellhaus, Inc., consulting engineers of Rapid City, South Dakota, reviewed by the Department of Energy and modified to provide steel valves and fittings In 1 ieu of the cast iron valves and fittings originally specified.

Bids for drilling the well were solicited from six well drillers. At the appointed time on the $26 t h$ of October, 1978 , no bids were received. The bid opening date was extended to November 8,1978 . At this time one bid was received in the amount of $\$ 217,134.94$.

In the company of a drilling consultant the low bidder's drilling rig was inspected. The drilling consultant confirmed that the drilling rig had the capability of drilling the well according to the specifications.

Notice of Award was issued December 14, 1978. The well driller proceeded at his own risk to move onto the well site and began driling the well prior to obtaining the contract and the performance bond.

The first 1000 feet of the well depth was drilled and cased with $10-3 / 4$ inch diameter casing. The contractor continued to dril1 and on December 31,1978 , was at a depth of 3540 feet. At 3756 feet the $3-1 / 2$ inch diameter drilling pipe and drill twisted off and backed-off which left at least three fish in the hole. After fishing out one 870 foot section and failing to remove the other fish, the contractor elected to plug the hole at approximately 2000 feet and wip stock. The contracto wipped stocked and completed drilling to a depth of 4266 feet. 
The well was flow tested and results indicate that the Philip Well will sustain a long term Artesian flow rate of 300 GPM of 155 degree F. water.

The design of modifications to the school heating systems was completed. A design review of the construction bid documents was conducted by members of the DOE team and the consulting engineer.

Routes for the discharge pipeline from the school buildings to the north fork of the Bad River were analyzed. The route through the Philip business district was selected as the most desirable. The selected route is closer to more potential users of the remaining heat in the water.

The design of the discharge pipeline and the service lines to the business buildings was completed. A design review of the construction documents was conducted.

The problem of removing the Radium 226 was addressed. The most economical method of removal appears to be by the addition of a Barium Chloride Treatment Plant.

The plans and specifications for the modifications to the school heating system were completed. These plans and specifications were reviewed at a meeting on November 19 and 20,1979. Changes and/or additions recommended at that meeting were made and the completed plans reviewed again on January 16 and $17,1980$.

The location of the Barium Chloride Treatment Plant was changed to a location that would not be objectionable to existing land uses. The new location is in an area that has not been developed to the extent of the previous location.

Because of the change in location of the Barium Chloride Plant and the alternate discharge point, the routes for the discharge pipeline from the school buildings to the treatment plant were re-analyzed. The route from the school to the railroad tracks was not changed. The more direct routes from the school to the treatement plant were rejected because of problems in obtaining the necessary easements. The City of Philip would not give permission to install the pipeline under their newly paved streets. This fact coupled with the problem of a heavily developed area that includes many mature trees made the direct route undesirable. The original route still has the advantage of being closer to more potential users of the remaining heat in the water.

The plans and specifications for the discharge and distribution lines for the heating district were completed. These were reviewed at a meeting on November 19 and 20, 1979. Revisions to the plans and specifications recommended at the meeting were completed. The plans and specifications included the piping at the well head, the discharge line from the school to the barium chloride treatment plant, a second line through the business district for a return line, the flow control system, and the barium chloride treatment plant.

The project was advertised and bids were received on February 27, 1980 for the construction of the project. Separate bids were requested for the modifications of the heating system under the title "Geothermal Conversion and Boiler Replacement" and for the discharge line under the title "Geothermal Distribution Pipeline". 
One bid was received for the Geothermal Distribution Pipeline contract and three bids were received for the Geothermal Conversion and Boiler Replacement contract.

The bid for the Geothermal Distribution Pipeline was above the estimate. Negotiations with the contractor reduced the price, and the Haakon School District awarded the contract to Ramstad, Inc.

The apparent low bid on the Geothermal Conversion and Boller Replacement contained several errors and was rejected. Negotiations were conducted with the second low bidder and the Haakon School District awarded this contract to Wolff's Heating and Plumbing.

The Department of Energy studied the bids, analyzed the total cost of the project and concurred in the award of the construction contracts.

The draft discharge permit prepared by the South Dakota Office of Water Quality was reviewed by the Permits Branch for EPA, Region Eight, Denver, Colorado. The required legal advertisement for comments were conducted. The comment perlod closed with no adverse comments. The discharge permit was issued by EPA, Denver.

Various methods of disposing of the sludge containing Radium 226, which will accumulate in the bottom of the ponds at the barium chloride treatment plant, were studied. After thirty years of operation there would be two options for disposal of the sludge. One is to remove the sludge from the area to an approved disposal site. Another is to add cement to the sludge at the site and use this mixture after is has hardened as the base for a new pond.

\section{PIPELINE}

The contractor began installation of the pipe at the well house and worked toward the High School boiler room, then to the Elementary School boller room, then to the business district and the control room in Philip Firehall. The South Dakota Department of Highways and the City of Philip required that all street crossings be made by augering under the street. The geothermal pipeline was placed in steel casing at all street crossings.

All segments of the geothermal pipeline were pulse tested prior to completion of the backfill and construction of concrete thrust blocks. The pipeline was tested by applying 225 to 250 pounds per square inch of pressure on the line with water at a temperature of approximately 140 to 150 degrees F. This pressure was maintained for a minimum of thirty minutes. The pressure was released and reapplied three times. After the pulse testing, pressure at 250 psi was malntained for a minimum of four hours.

The depth from ground Iine to top of pipe was a minimum of $s i x$ and one-half feet. The trench was excavated so that $s i x$ inches of sand was placed under the pipe. The sand which all passed a 3/8" screen, was obtained from a local source. Another six inches of sand was placed over the pipe. The sand was placed to provide a cushion around the pipe. This cushion is necessary in this area because of the expansive solls through which the pipe was laid. The soil expands and contracts with changes of moisture. 
Tees with blind flanges were added to the geothermal fluid supply and return lines for future additions to the heating district at three different locations. The pipeline to carry the geothermal fluid from the School to the discharge point was ready for operation on November 4, 1980. The well was permitted to flow at a rate of approximately $320 \mathrm{gpm}$ for several days to bring the pipe and surrounding ground up to a stabilized temperature. The school used the heat from the flow for both space and domestic water heating.

The volume of geothermal fluid flowing through the system is controlled by a motorized modulating control valve in the well house. This control valve is set for full open at approximately 30 degrees and approximately $1 / 3$ open at 60 to 65 degrees. Some flow is required to provide domestic hot water for the school.

\section{OPERATION OF THE GEOTHERMAL SYSTEM}

The entire system operates automatically with very little operator effort required. A recording flow meter at the well head records the flow in gallons per minute. A recording thermometer at the downstream end of the system records the temperature of the geothermal fluid after it has passed through all of the heating systems. Operator effort is required for the following:

Normal lubrication of pump and fan motors.

Monitoring and when necessary changing filters on air handling equipment.

Reading the flow meter at the well head.

Changing the chart on the recording thermometer.

Obtaining samples of the affluent leaving the settling ponds once each month and sending them to the laboratory for analysis.

Maintaining the supply of barium chloride in the mixing tanks at the treatment plant.

Removing the static mixer from the pipeline and cleaning when necessary.

During the winter of 1980-81, the school buildings were heated entirely by the geothermal system after it was placed in operation in Novmeber of 1980 . Only one business obtained heat from the geothermal system during the winter of 1980-81. The other business systems had not yet been completed. During the winter of 1981-82, the school buildings were heated entirely by the geothermal heating system except for one 2-hour period when the boilers in the elementary school were operated to counteract excessive heat loss adjacent to leaky windows when the chill factor exceeded -55 degrees $F$. Six of the eight business district systems obtained more than $90 \%$ of their heat from the geothermal system. Two of the business systems which were not designed to provide $100 \%$ of the heat, obtained more than $75 \%$ of the heat from the geothermal system.

The Barium Chloride Treatment Plant requires the greatest expenditure of operator effort. Two small pumps supply the barlum chloride to the static mixer through which the geothermal fluid flows. The reaction to the introduction of barium chloride occurs in the mixer and along the pipes downstream from the mixer. Barium sulfate precipitates on the veins and walls of the static mixer and the pipes. Accumulation of barium sulfate reduces 
the cross-section area of the pipe, and increases pressure in the system. Removing the static mixer from the line, cleaning the sulfate deposits from the vanes and walls and replacing the static mixer in the line requires from one to three hours. A new static mixer was designed to replace the stainless steel manufactured mixer in an attempt to delay the reaction. This experiment has only been partially successful, in that the reaction is delayed and the sulfate precipitate is soft and easily removed.

Barlum chloride treatment was suspended in September, October and November of 1981 due to the barium chloride pump fallure and excessive deposits on one of the pipeline valves. An analysis of the affluent samples on November 24, 1981, showed 92.4 3.3 pico curies per liter of Radium 226. Analysis of this sample on December 16, 1981, after treatment with the new static mixer, showed that the Radium 226 content was 30.01 .6 pico curies per liter.

Proposed modifications to the system include relocating the static mixer to discharge into an open trough with baffles to complete the mixing and allow time for the reaction perlod. The open trough would be installed at ground level, thereby eliminating much of the work involved in removing the precipitate. 
ARMORY-HIGH SCHOOL BOILER ROOM

Month: February Year: 1981

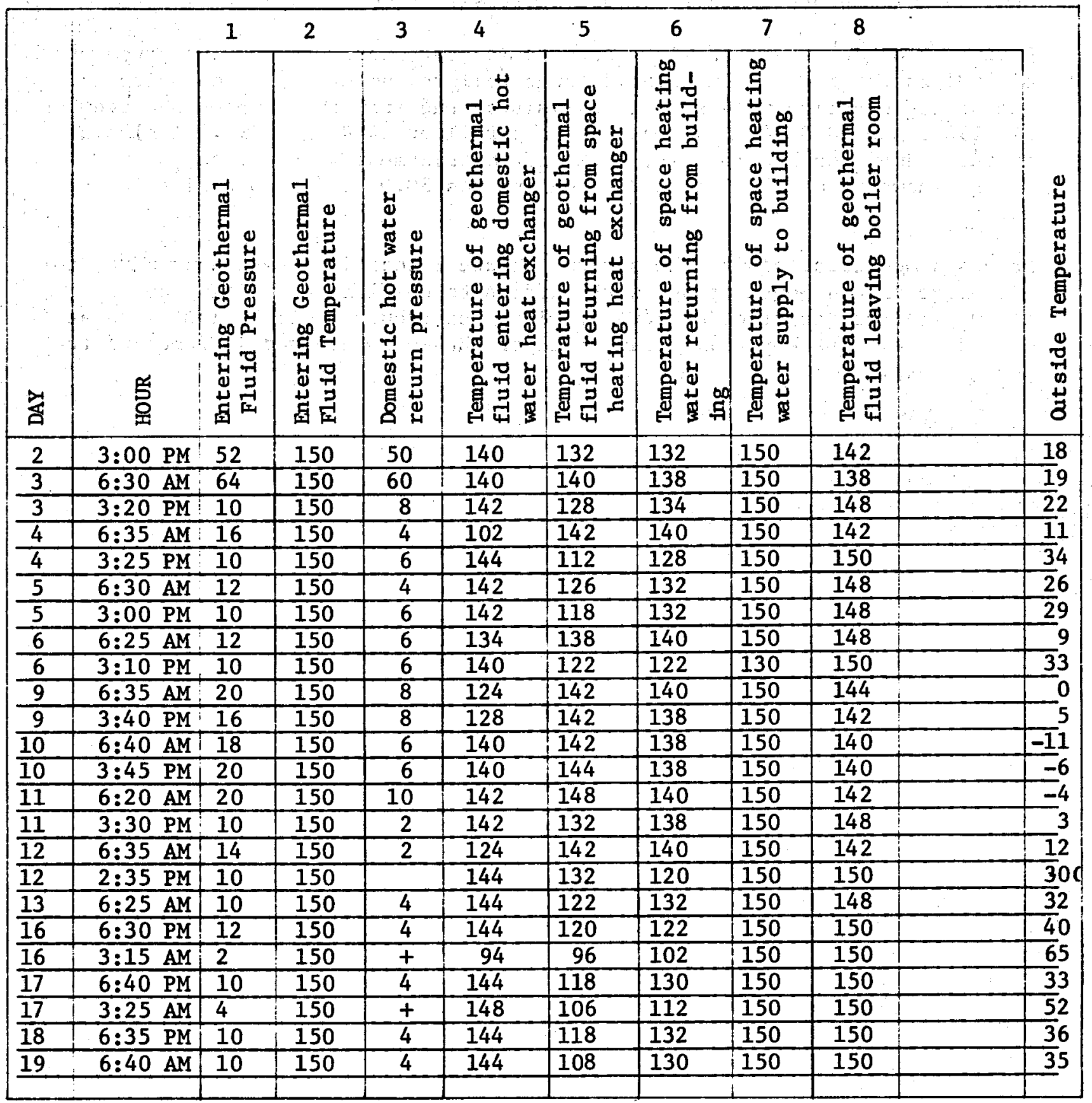

TABLE 1 


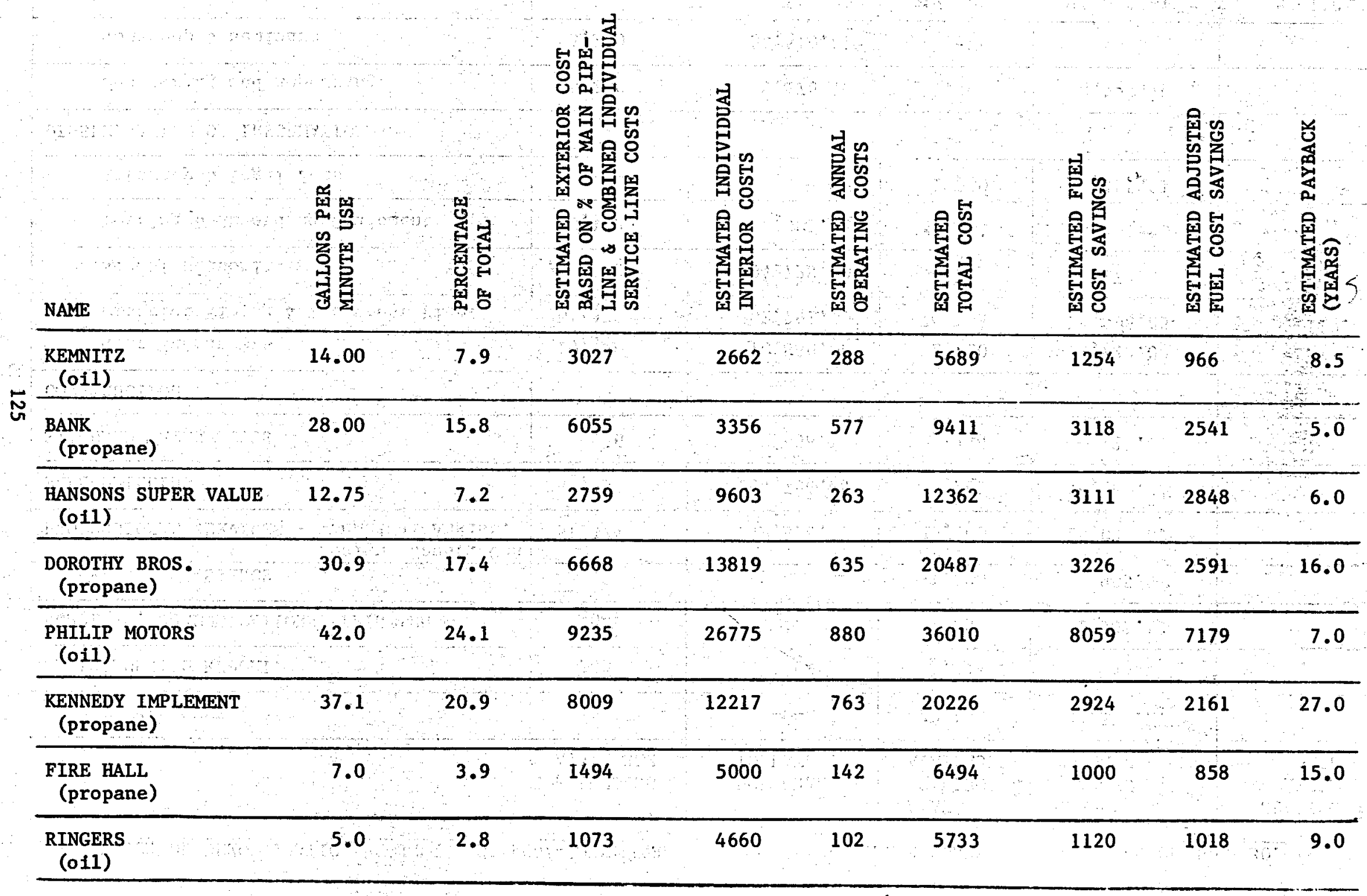


PHILIP SCHOOL DEMONSTRATION PROJECT - DE FC07-78ET27080

FINANCIAL SUMMARY

AS OF June 30,1982

\begin{tabular}{|c|c|c|c|c|c|}
\hline 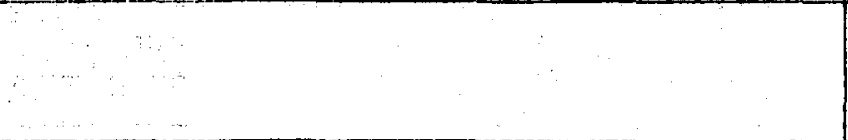 & $\begin{array}{l}\text { DOE FUNDING } \\
\text { AVAILABLE }\end{array}$ & $\begin{array}{l}\text { DOE CHARGES } \\
\text { TO DATE }\end{array}$ & $\begin{array}{l}\text { HAAKON } \\
\text { FUNDING } \\
\text { AVAILABLE }\end{array}$ & $\begin{array}{l}\text { HAAKON } \\
\text { CHARGES } \\
\text { TO DATE }\end{array}$ & $\begin{array}{l}\text { HEATING DIST. } \\
\text { CHARGES } \\
\text { TO DATE }\end{array}$ \\
\hline PROGRAM MANAGEMENT & $-0-$ & $-0-$ & 20,166 & $23,534.84$ & \\
\hline ENVIRONMENTAL REPORT & 762 & 762 & 1,238 & 83.02 & \\
\hline SUPPLIES, COMMUNICATIONS, PRINTING & $-0-$ & - & 1,200 & $1,507.13$ & \\
\hline TRAVEL \& SUBSISTENCE & -0 & - & 1,600 & 995.57 & \\
\hline $\begin{array}{c}\text { Design, Const, Obs } \\
\text { PROFESSIONAL SERVICES - Technical Assist. }\end{array}$ & 51,374 & $49,878.53$ & 25,000 & $25,034.69$ & \\
\hline WELL DRILLING & 264,755 & $264,754.84$ & 46,762 & $46,761.07$ & \\
\hline STANDARD WATER TESTS & 956 & 638.15 & 239 & 127.43 & \\
\hline CONSTRUCTION & - & & & & \\
\hline Heat Exchangers & 10,880 & $10,880.00$ & 2,720 & $2,720.00$ & \\
\hline District Piping \& Treatment Plant & 301,372 & $301,791.59$ & 74,593 & $74,596.65$ & $52,110.00^{-}$ \\
\hline School Retrofit & 294,728 & $294,728.00$ & 36,751 & $34,272.00$ & \\
\hline Testing \& Recording Equipment & 6,122 & $2,901.42$ & 1,531 & 701.90 & \\
\hline Attorney \& Lega1 Fees & $-0-$ & & 1,000 & $1,555.91$ & \\
\hline DISSEMINATION OF INFORMATION & - & & & & \\
\hline Monitoring and Reporting & 5,200 & $8,176.47$ & 5,200 & $2,552.40$ & \\
\hline Workshop \& Seminars & 5,250 & $934,510.42$ & $-0-$ & & \\
\hline TOTAL & & & 218,000 & $214,442.61$ & $52,110.00$ \\
\hline
\end{tabular}

TABLE 3 


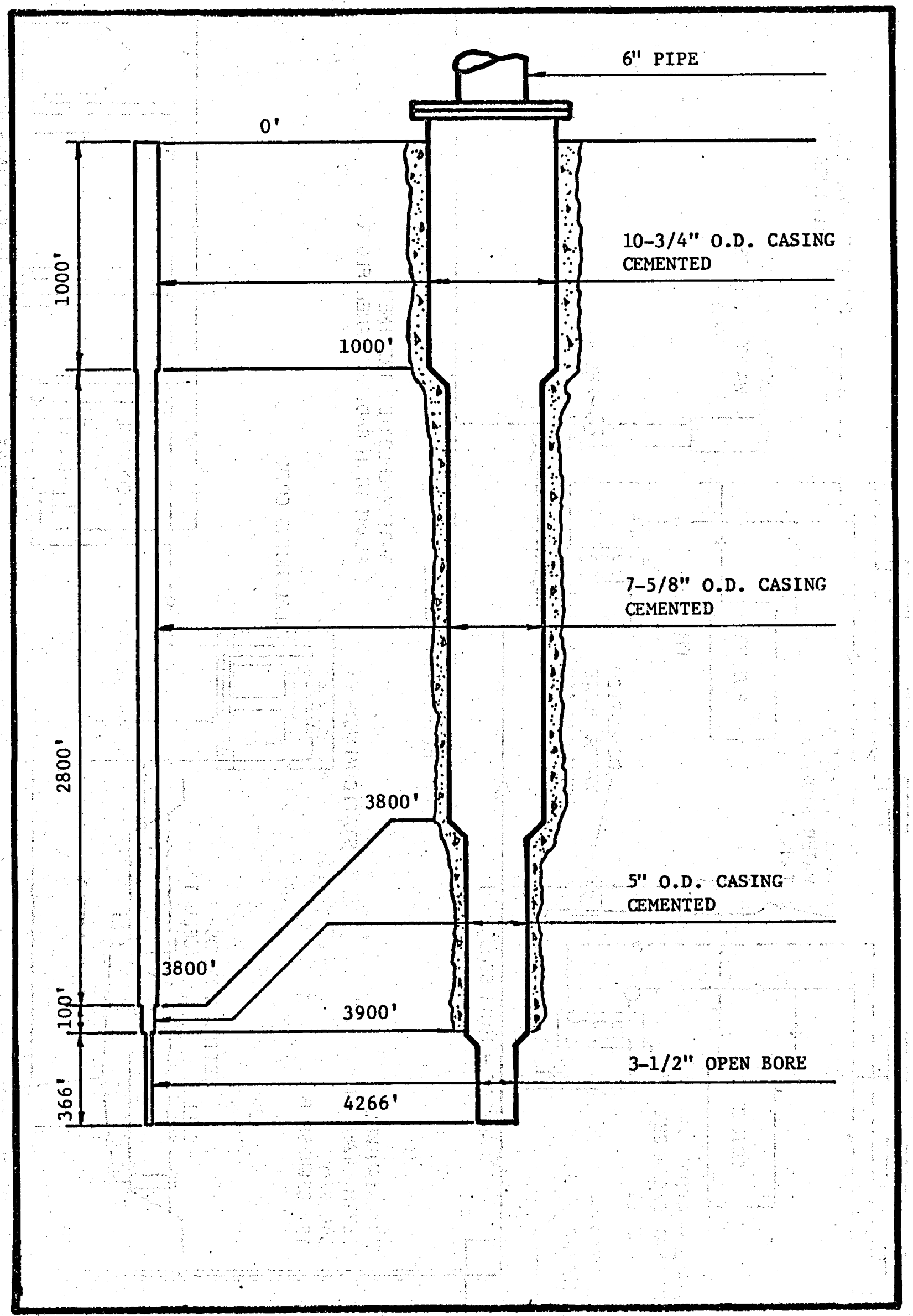

FIGURE 1. HAAKON SCHOOL WELL DIAGRAM 


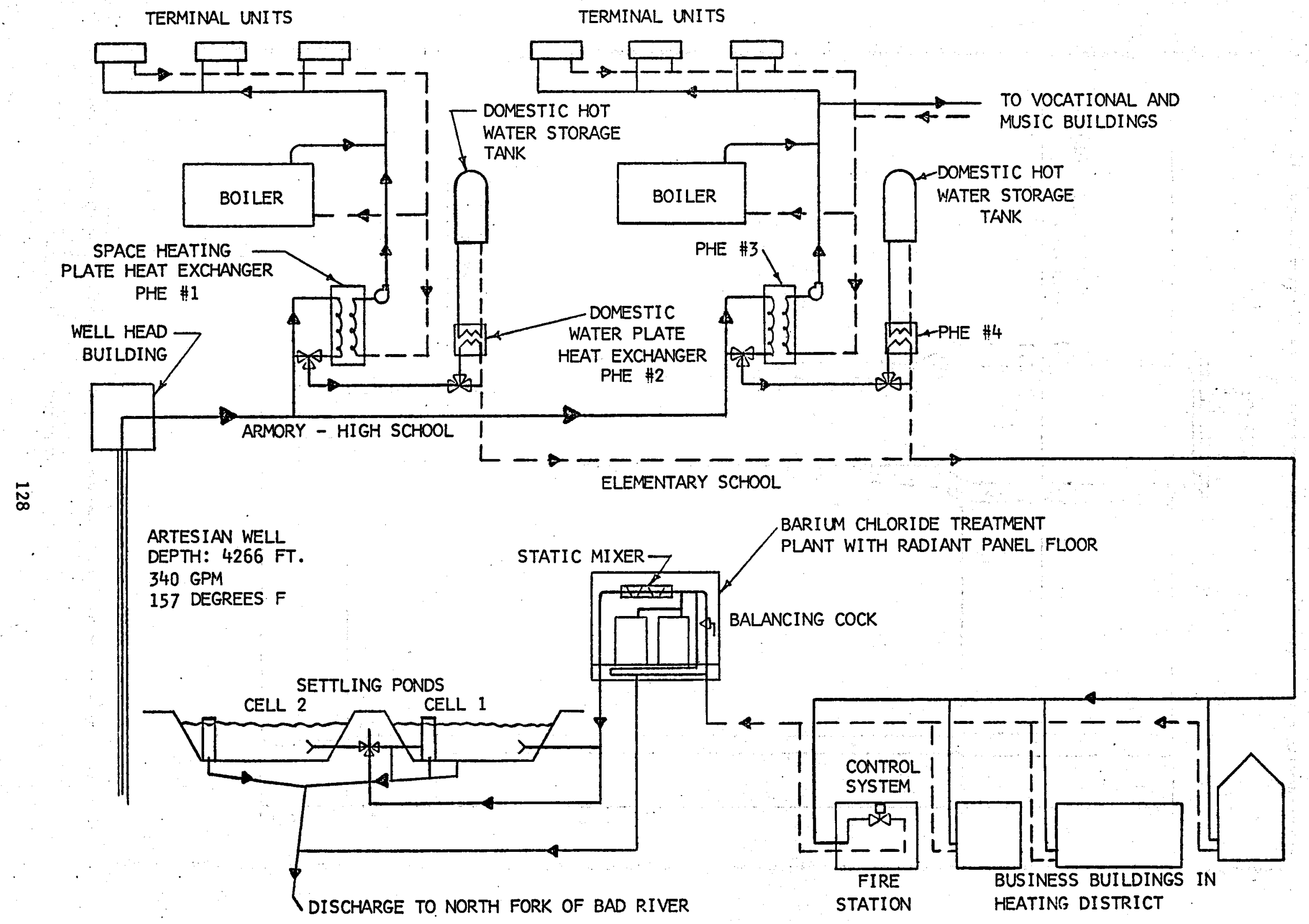

